UNIVERSIDADE DE SÃO PAULO

ESCOLA DE ARTES, CIÊNCIAS E HUMANIDADES

PROGRAMA DE PÓS-GRADUAÇÃO EM GERONTOLOGIA

BRUNA VALQUIRIA BAVIERA

INTERDISCIPLINARIDADE E INTERPROFISSIONALIDADE:

PERCEPÇÕES DOS PROFISSIONAIS ENVOLVIDOS

NO ATENDIMENTO AMBULATORIAL DO IDOSO

São Paulo

2017 


\section{INTERDISCIPLINARIDADE E INTERPROFISSIONALIDADE: PERCEPÇÕES DOS PROFISSIONAIS ENVOLVIDOS NO ATENDIMENTO AMBULATORIAL DO IDOSO}

Dissertação apresentada à Escola de Artes, Ciências e Humanidades da Universidade de São Paulo para obtenção do título de Mestre em Ciências pelo Programa de Pós-Graduação em Gerontologia.

Versão corrigida contendo as alterações solicitadas pela comissão julgadora 11 de Outubro de 2017. A versão original encontra-se em acervo reservado na Biblioteca da EACH/USP e na Biblioteca Digital de Teses e Dissertações da USP (BDTD), de acordo com a Resolução CoPGr 6018, de 13 de outubro de 2011.

Área de concentração: Gestão Gerontológica

Orientadora: Prof. Dra. Beatriz Aparecida Ozello Gutierrez 
Autorizo a reprodução e divulgação total ou parcial deste trabalho, por qualquer meio convencional ou eletrônico, para fins de estudo e pesquisa, desde que citada a fonte.

Baviera, Bruna Valquiria

Interdisciplinaridade e interprofissionalidade : percepções dos profissionais envolvidos no atendimento ambulatorial do idoso / Bruna Valquiria Baviera ; orientadora, Beatriz Aparecida Ozello Gutierrez. - 2017 $112 \mathrm{f}$.

Dissertação (Mestrado em Ciências) - Programa de PósGraduação em Gerontologia, Escola de Artes, Ciências e Humanidades, Universidade de São Paulo, São Paulo Versão corrigida

1. Assistência a idosos. 2. Profissionais de saúde. 3 . Assistência ambulatorial. 4. Interdisciplinaridade. I. Gutierrez, Beatriz Aparecida Ozello, orient. II. Título 
Nome: BAVIERA, Bruna Valquiria

Interdisciplinaridade e interprofissionalidade: percepções dos profissionais envolvidos no atendimento ambulatorial do idoso

Dissertação apresentada à Escola de Artes, Ciências e Humanidades da Universidade de São Paulo para obtenção do título de Mestre em Ciências do Programa de Pós-Graduação em Gerontologia.

Área de Concentração:

Gestão Gerontológica

Aprovado em: 11 / 10 / 2017

\section{Banca Examinadora}

Profa. Dra. Naira de Fátima Dutra Lemos

Universidade Federal de São Paulo. Escola Paulista de Medicina

Profa. Dra. Marina Peduzzi

Universidade de São Paulo. Escola de Enfermagem

Profa. Dra. Rosa Yuka Sato Chubaci

Universidade de São Paulo. Escola de Artes, Ciências e Humanidades 


\section{Dedicatória}

Dedico este trabalho a todos os profissionais que passaram pelo meu caminho e me inspiraram na busca por um cuidado de qualidade ao idoso.

Também a todos os idosos que me motivaram nesta busca pelo melhor sempre.

$E$ a todos os professores que se dedicam firmemente à formação de profissionais que consigam alcançar o idoso em sua complexidade.

Aos meus queridos pais, que nunca desistiram de incentivar meu crescimento acadêmico e profissional e tem suportado por todos estes anos a distância e as saudades.

Dedico especialmente à Kizz de Brito Barretto, que todos os dias regou esta sementinha dentro de mim, para que este trabalho desse flores e frutos. 


\section{Agradecimentos}

Um agradecimento especial ao Centro de Referência do Idoso da Zona Norte, que permitiu a realização deste estudo, e a todos os colegas de trabalho pela compreensão e apoio.

Agradeço também aos profissionais da equipe de Reabilitação da instituição, pela compreensão e parceria em todos os momentos.

Agradeço aos professores da pós-graduação em Gerontologia da EACH USP, pela oportunidade deste aprendizado tão rico com vocês.

Agradeço a minha querida orientadora Beatriz Gutierrez, por todo apoio e parceria nesta caminhada.

Agradeço por fim, à Kizz e à Desiree, que sempre trouxeram momentos de carinho e acolhimento, nunca me deixando esquecer das coisas mais importantes da vida. 
"Eu antes tinha querido ser os outros para conhecer o que não era eu. Entendi então que eu já tinha sido os outros e isso era fácil. Minha experiência maior seria ser o outro dos outros: e o outro dos outros era eu."

(Clarice Lispector) 


\section{Resumo}

BAVIERA, Bruna Valquiria. Interdisciplinaridade e interprofissionalidade: percepções dos profissionais envolvidos no atendimento ambulatorial do idoso. 2017. 112 f. Dissertação (Mestrado em Ciências) - Escola de Artes, Ciências e Humanidades, Universidade de São Paulo, São Paulo, 2017. Versão Corrigida.

A interdisciplinaridade e a interprofissionalidade são componentes essenciais da Gerontologia e do trabalho em equipe no atendimento de saúde do idoso. Entretanto, dificuldades podem surgir para a real implementação destes conceitos na prática gerontológica. Este estudo visou levantar as percepções de uma equipe de profissionais que atua em um ambulatório especializado no atendimento gerontológico a respeito da interdisciplinaridade e da interprofissionalidade em sua formação e cotidiano de trabalho com idosos. Trata-se de pesquisa descritiva, de natureza qualitativa, sob influência de alguns pressupostos alinhados à hermenêutica gadameriana. $O$ instrumento utilizado para coleta dos dados foi um questionário semiestruturado desenvolvido pela pesquisadora e a realização de um grupo focal. Os dados foram categorizados por meio da técnica de análise de conteúdo proposta por Minayo. Participaram da pesquisa 21 profissionais de diferentes áreas de formação, que responderam o questionário que continha perguntas sobre suas percepções e sobre o contato que tiveram com os conceitos em sua formação acadêmica e profissional. Dentre estes profissionais, 12 vivenciaram o grupo focal para discussão sobre o tema. Os principais resultados apontaram que estes profissionais conseguem enxergar a importância da interdisciplinaridade e da interprofissionalidade em sua atuação profissional, mesmo que alguns deles tenham dificuldades em definir os conceitos, sendo que os que manifestaram tal dificuldade tinham um maior tempo de experiência na atuação gerontológica. Apontaram ainda que $48 \%$ deles revelaram contato com os conceitos em sua graduação e $80 \%$ tiveram durante sua pós-graduação. Os participantes também sinalizaram barreiras e fatores facilitadores para aplicar os conceitos em prática, apresentando aspectos do relacionamento com outros profissionais e questões institucionais. Frente a esses resultados percebeu-se a necessidade de observação mais próxima da prática destes profissionais visando verificar se de fato os conceitos abordados na teoria estão presentes no cuidado prestado aos idosos. Salienta-se sobre a importância do papel institucional na educação permanente destes profissionais e o compromisso ético e de responsabilidade dos mesmos em se manterem atualizados em relação aos temas centrais da gerontologia e do trabalho em equipe.

Palavras-chave: Interdisciplinaridade. Interprofissionalidade. Gerontologia. 


\begin{abstract}
BAVIERA, Bruna Valquiria. Interdisciplinarity and interprofessionality: perceptions of professionals involved in the outpatient care of the elderly. 2017.112 p. Dissertation (Master of Science) - School of Arts, Sciences and Humanities, University of São Paulo, São Paulo, 2017. Corrected version.

Interdisciplinarity and interprofessionality are essential components of gerontology and teamwork in elderly health care. However, difficulties can arise for the real implementation of these concepts in gerontological practice. This study aims to raise the perceptions of a team of professionals who work in an outpatient clinic specialized in gerontological care regarding interdisciplinarity and interprofessionality in their training and daily work with the elderly. It is a descriptive research, of qualitative nature, under the influence of some assumptions aligned to the Gadamerian hermeneutics. The instrument used for data collection was a semi-structured questionnaire developed by the researcher and the accomplishment of a focal group. The data were categorized by means of the content analysis technique proposed by Minayo. Twenty-one professionals from different training areas participated in the study, who answered the questionnaire that contained questions about their perceptions and about the contact they had with the concepts in their academic and professional training. Among these professionals, 12 experienced the focus group to discuss the theme. The main results pointed out that these professionals can see the importance of interdisciplinarity and interprofessionality in their professional performance, even though some of them have difficulties in defining the concepts and those who manifested such difficulty had a longer experience in gerontology. They also pointed out that $48 \%$ of them revealed contact with the concepts in their graduation and $80 \%$ had during their postgraduate studies. Participants also flagged barriers and facilitating factors to apply the concepts in practice, presenting aspects of the relationship with other professionals and institutional issues. In view of these results, it was noticed the need for closer observation of the practice of these professionals in order to verify if in fact the concepts covered in the theory are present in the care given to the elderly. It is emphasized the importance of the institutional role in the permanent education of these professionals and the ethical commitment and responsibility of these professionals to keep up to date of the central themes of gerontology and teamwork.
\end{abstract}

Keywords: Interdisciplinarity. Interprofessionality. Gerontology. 


\section{Lista de tabelas}

Tabela 1: descrição do número de participantes por áreas de Graduação .44

Tabela 2 - áreas de pós-graduação dos participantes .45 


\section{Lista de figuras}

Figura 1: contato que os participantes tiveram com a interdisciplinaridade e a interprofissionalidade durante a graduação.

Figura 2: contato que os participantes tiveram com a interdisciplinaridade e a

interprofissionalidade durante a pós-graduação.

Figura 3: definição de interdisciplinaridade na perspectiva dos participantes do estudo. ..... 52

Figura 4: definição de interprofissionalidade na perspectiva dos participantes do estudo. ...54

Figura 5: importância da interdisciplinaridade na atuação profissional, de acordo com os participantes do estudo. 58

Figura 6: importância da interprofissionalidade na atuação profissional, de acordo com os participantes do estudo 60

Figura 7: fatores que contribuem para a interdisciplinaridade e a interprofissionalidade na perspectiva dos participantes do estudo. 63

Figura 8: barreira para a interdisciplinaridade e a interprofissionalidade na perspectiva dos participantes do estudo. 65

Figura 9: fatores que contribuíram para o aprendizado da interdisciplinaridade e interprofissionalidade com a prática profissional. 


\section{Sumário}

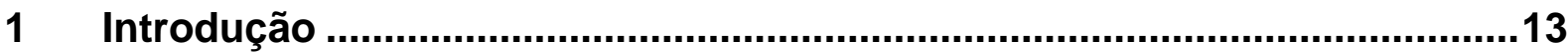

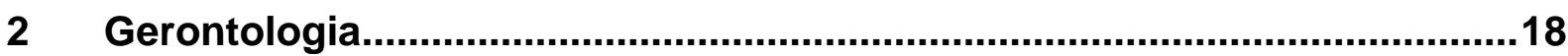

2.1 Aspectos históricos e a gerontologia como ciência interdisciplinar .........19

2.2 A formação de profissionais para atuar com idosos ................................21

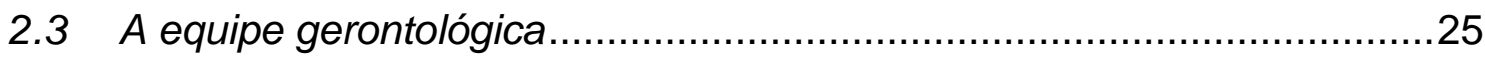

2.4 O atendimento integral do idoso .......................................................28

3 Interdisciplinaridade e interprofissionalidade: do desafio conceitual ao

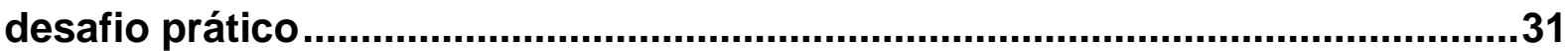

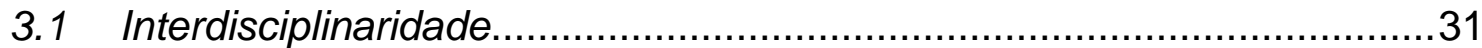

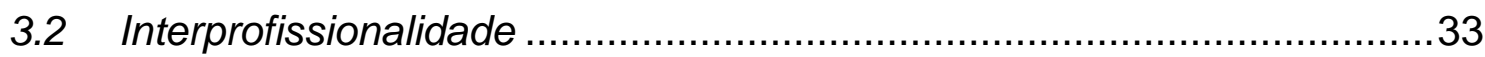

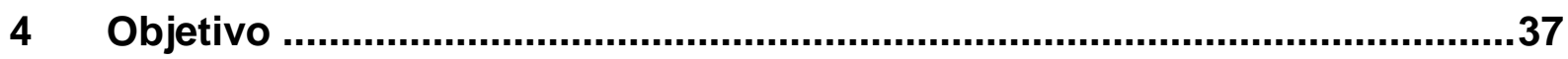

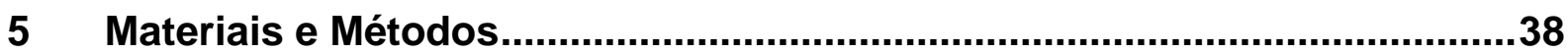

5.1 Local e procedimentos da coleta dos dados ........................................38

5.2 Análise dos dados coletados ............................................................ 41

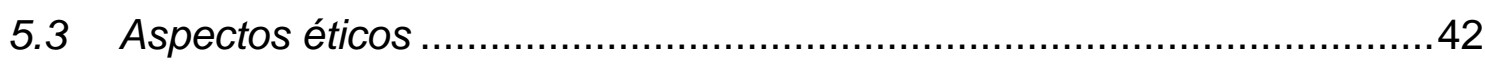

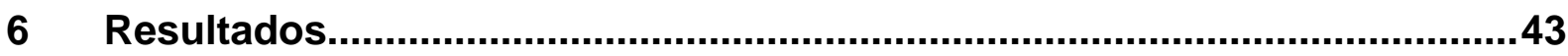

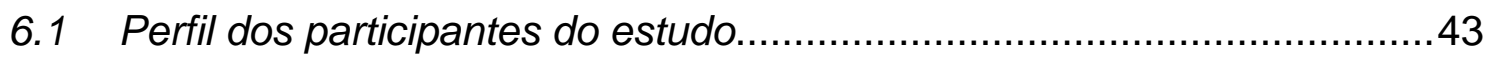

6.1.1 .... Acesso a conteúdos sobre envelhecimento na graduação e pósgraduação

6.1.2 …........... Acesso a interdisciplinaridade e interprofissionalidade na graduação

6.1.3 .........Acesso a interdisciplinaridade e interprofissionalidade na pósgraduação .50

6.2 Definição dos conceitos.

6.3 A importância da interdisciplinaridade e da interprofissionalidade para a atuação profissional.....

6.3.1 A importância da interdisciplinaridade para a atuação profissional 
6.3.2 A importância da interprofissionalidade para a atuação profissional

6.3.3 O dia a dia de trabalho: fatores facilitadores e fatores dificultadores

6.4 Aprendendo habilidades de interdisciplinaridade e interprofissionalidade ..68

7 Discussão. . .72

7.1 Sobre o perfil de formação dos participantes e suas percepções a respeito dos conceitos .72

7.2 Como melhorar as ações integradas no cotidiano de trabalho com idosos

8 Limitações

9 Considerações finais .85

Referências .88

Apêndice A - QUESTIONÁRIO . .96

Apêndice B - TERMO DE CONSENTIMENTO LIVRE E ESCLARECIDO . .98

Apêndice C - ROTEIRO PARA GRUPO FOCAL . .99

Anexo A - CARTA DE AUTORIZAÇÃO

Anexo B - APROVAÇÃO DO COMITÊ DE ÉTICA EM PESQUISA ...................101

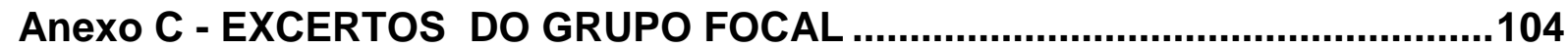




\section{Introdução}

O presente estudo se concentra na linha de pesquisa "Gestão Gerontológica", abordando os temas da interdisciplinaridade e interprofissionalidade no atendimento de saúde em gerontologia, como forma de analisar a percepção dos profissionais de saúde, que atuam em um serviço secundário de atendimento a idosos, sobre a interdisciplinaridade e a interprofissionalidade, abordando aspectos como a relevância, os desafios na sua implementação e sugestões para que de fato elas possam ser colocadas em prática.

Esclarecemos aqui as diferenças entre os planos disciplinares e profissionais. A interdisciplinaridade se refere a conceitos e teorias voltados para a compreensão de fenômenos, enquanto a interprofissionalidade diz respeito a práticas voltadas à solução de problemas empíricos específicos (Furtado, 2009). Portanto, o sufixo "disciplinar" será usado no presente trabalho se referindo ao campo dos saberes e o sufixo "profissional" ao das equipes e seus serviços. Tal discussão será apresentada neste trabalho dentro do contexto dos serviços e políticas de saúde direcionados aos idosos.

Japiassu (Japiassu, 1976, apud: Peduzzi, et al , 2013) descreveu os diferentes níveis de contato entre as disciplinas: na muldisciplinaridade, não há nenhuma cooperação entre as disciplinas, na pluridisciplinaridade, há cooperação entre as disciplinas, mas sem coordenação, na interdisciplinaridade há uma axiomática comum a um grupo de disciplinas conexas coordenadas por uma delas, que ocupa uma posição hierárquica superior e, finalmente, a transdisciplinaridade, envolve uma coordenação de todas as disciplinas, com base em uma axiomática geral.

Ao que Japiassu (1976) referiu sobre a necessidade de uma disciplina ocupar uma posição hierárquica superior em relação às outras na interdisciplinaridade, outros 
autores discordam e afirmaram que não há necessidade de ter classes de disciplinas dominantes para que a interdisciplinaridade aconteça de fato. Nesse sentido, a hierarquia atrapalharia o desenvolvimento da mesma (Frigotto, 2011). Nessa mesma direção, Etges (2011) apontou a ideia de que uma disciplina seja superior às outras, sendo uma ciência única e universal, como uma forma equivocada de interdisciplinaridade, ao qual ele chama de interdisciplinaridade generalizadora.

Nestes termos, apresentamos as definições trazidas por Minayo (2010), que tece suas percepções para os conceitos multi, inter e transdisciplinaridade. Para a autora, multidisciplinaridade se constitui da justaposição de disciplinas, cada uma com suas teorias e metodologias próprias. Já a interdisciplinaridade constitui uma articulação de várias disciplinas em que o foco é o objeto, o problema ou o tema complexo, para o qual não basta a resposta de uma área só. Ao produto final da interdisciplinaridade chamamos transdisciplinaridade, cuja ação

(...) é a resultante da capacidade que nós temos de ultrapassar as fronteiras das disciplinas pelo investimento articulado e a contribuição das diferentes disciplinas em jogo, num processo de investigação que inclui articulação de teorias e conceitos, métodos e técnicas e, não menos importante, do diálogo entre as pessoas (Minayo, 2010, p. 437).

Em relação à importância do diálogo destacada na citação acima, o trabalho em saúde é marcado pelas relações interpessoais entre os profissionais e usuários. É um trabalho reflexivo e dependente do recrutamento de saberes de diversas áreas. Apresenta como características a complexidade, isto é, ele incorpora a diversidade profissional, dos atores e interesses, das tecnologias, da organização do espaço; a heterogeneidade devido à variedade de processos de trabalhos coexistentes; e a 
fragmentação conceitual, do pensar e fazer, da técnica e do social (Motta; Aguiar, 2007).

Reeves (2016) discorreu sobre necessidade da educação interprofissional em saúde, afirmando a natureza multifacetada e complexa da área, na qual a colaboração entre os profissionais é essencial para a atenção eficaz e integral. Discorreu ainda, sobre a necessidade da educação interprofissional fazer parte do desenvolvimento profissional contínuo do indivíduo, seja em âmbito formal ou informal.

Peduzzi e colaboradores (2013) ressaltaram a importância de uma abordagem integral que contemple as múltiplas dimensões das necessidades de saúde dos usuários e da população, principalmente devido às mudanças no perfil epidemiológico, com o aumento da expectativa de vida e das condições crônicas de saúde, que requerem um acompanhamento prolongado e mais complexo desses indivíduos. Para uma efetividade deste cuidado, torna-se essencial a qualidade da comunicação e colaboração entre os diferentes profissionais envolvidos.

Nesse sentido, esse trabalho procurou escutar os profissionais de saúde que atuam com idosos, na busca de entender os aspectos relacionados à interdisciplinaridade e interprofissionalidade, partindo da consonância dos princípios estudados e o que é preconizado pelo Sistema Único de Saúde (SUS), possa se pensar em estratégias em todos os níveis - organizacionais, de formação profissional e de políticas públicas - para que de fato estas práticas façam parte do cotidiano, na busca do atendimento de saúde eficaz e de qualidade aos idosos.

Jacob Filho (2011) afirmou que

seja qual for o adjetivo dado ao programa ou à equipe, o que realmente importa é que as atitudes sejam verdadeiramente multi, inter e transdisciplinares para que as finalidades sejam objetivamente alcançadas (Jacob Filho, 2011, p.21). 
Nessa linha de pensamento, o objeto deste estudo foi escolhido em decorrência da sua relevância temática e parte da necessidade de investigar qual é a percepção dos profissionais de saúde que atuam com idosos a respeito da interdisciplinaridade e interprofissionalidade. Esta traduz-se sem dúvida, em uma atitude diferenciada de uma equipe de saúde frente ao envelhecimento e aos seus desafios.

Ora, indubitavelmente, a equipe de saúde que vivencia de fato a essência interprofissional, incorporando-a como uma atitude do quadro de profissionais, possibilita a retomada do humano como valor primordial e sem descuidar da sua multiplicidade (Ayres, 2004). De acordo com Telles e Borges (2010), o resgate da "medida do humano", por meio da interdisciplinaridade, assume maior relevância quando os serviços de saúde vêm lidando com questões específicas do envelhecimento, em uma demanda crescente.

Com efeito, é imprescindível que a interdisciplinaridade e a interprofissionalidade, para além de estratégias; para além de uma adjetivação e metodologias, consubstanciem em uma possibilidade real de trocas de saberes da equipe prestadora dos serviços de saúde, capaz de fornecer feixe amplo de luz sobre os processos e demandas que entrecortam os serviços de atendimento ao idoso.

Nesse passo, o presente trabalho se propôs a entender de que maneira a interdisciplinaridade e a interprofissionalidade acontecem para estes profissionais, e qual a sua relevância nos processos de atendimento de saúde ao idoso.

Aliás, com razão, Rodrigues (2002), no artigo "Caminhos da transdisciplinaridade: fugindo a injunções lineares" preconizou que:

O fenômeno interdisciplinar está distante de ser evidente. Por ganhar considerável expressão, merece ser elucidado tanto na perspectiva conceitual, quanto no campo investigativo, de modo a operacionalizálo. Neste contexto, é compreensível a necessidade de rigor e 
detalhamento para efetivação interdisciplinar com cuidado para escapar a modismos e ou à vulgarização de sua utilização (online).

Nesse tocante, o presente trabalho procurou analisar como a interdisciplinaridade e a interprofissionalidade ocorrem para estes profissionais, prestadores de serviços de saúde aos idosos, como forma de delimitar algumas das dificuldades que podem estar atravancando que a efetiva postura do grupo de profissionais se desenvolva centrada nos benefícios da interdisciplinaridade e, sem alargar as dificuldades já evidentes em processos que ultrapassam o foco numa única disciplina, e fatores que agem de forma positiva no contexto do trabalho em equipe gerontológica.

Se a comunicação e a sinergia da equipe interprofissional de assistência ao idoso proporcionam melhor qualidade e efetividade do serviço de saúde, fornecido à população idosa, é indispensável detectar algumas das principais práticas e inações desse grupo de múltiplos profissionais que podem afastá-lo do ideal de colaboração; tão marcante na postura cunhada pela essência da interdisciplinaridade e da interprofissionalidade.

Os resultados que serão apresentados neste trabalho repercutem diretamente na possibilidade de melhoria nas dinâmicas de atendimento aos idosos e, mais ainda, ecoa culminando em eficiência das políticas públicas direcionadas a essa população e provável impacto econômico para o governo, resultante do menor número de complicações no estado de saúde destes idosos e, também na possibilidade da incorporação de novas abordagens na formação destes profissionais que atuam na área da Gerontologia. 


\section{Gerontologia}

Pavarini et al. (2005) apresentaram a gerontologia como a ciência que estuda o processo de envelhecimento em suas mais diversas dimensões e se constitui em uma especialidade composta por diferentes profissões. Dentro do seu conjunto de conhecimento, pode-se dizer que a gerontologia é multidisciplinar, à medida que reúne conceitos teóricos provenientes de diferentes disciplinas, e é interdisciplinar em função da complexidade do fenômeno da velhice. Assim, pode-se dizer que a gerontologia é uma ciência transversal, porque ela não pode ser explicada ou definida somente por um determinado ramo específico da ciência (Pavarini et al, 2005).

Em seu livro Palavras-chave em Gerontologia (2014), Neri definiu a Gerontologia como:

campo interdisciplinar que tem como objetivos descrever e explicar as mudanças típicas do processo de envelhecimento humano e suas relações com os determinantes genético-biológicos, psicológicos e socioculturais. Interessa-se pelo estudo das características dos idosos, bem como pelas várias experiências de velhice e envelhecimento ocorridas em diferentes contextos socioculturais e históricos. Abrange aspectos do envelhecimento normal e patológico. Compreende a consideração dos níveis atuais e do potencial para o desenvolvimento. Em seu aspecto aplicado, a gerontologia interessase pela solução de problemas de ordem física, social e psicológica associados ao envelhecimento e pela promoção da qualidade de vida na velhice em indivíduos e populações (Neri, 2014, p.187).

Nessa linha de pensamento, a Gerontologia é intrinsecamente interdisciplinar, pois o processo de envelhecimento permeia todos os aspectos da vida, incorporando aspectos científicos e técnicos de vários campos. Seu campo de saber, competências e responsabilidades confluentes às diversas profissões são caracteristicamente 
intersetoriais, com a participação potencial de todas as ciências que estudam e atuam no envelhecimento (Motta; Aguiar, 2007).

A seguir, apresentaremos uma discussão histórica sobre a interdisciplinaridade na gerontologia, mostrando a evolução deste conceito.

\subsection{Aspectos históricos e a gerontologia como ciência interdisciplinar}

A gerontologia tem como seu precursor Elie Metchknikoff, que em 1903 percebeu a necessidade da criação da especialidade para o estudo do envelhecimento, da velhice e dos idosos. Em 1909, também houve o interesse em se criar uma nova especialidade na Medicina, que foi denominada geriatria por Ignatz Nascher, cujo significado era o estudo clínico da velhice. Os dois autores tiveram dificuldades para disseminar suas ideias entre os médicos da época.

Papaléo Netto (2011) destacou que Nascher já se adiantava ao processo de crescimento da ciência do envelhecimento, ao antever a necessidade de uma abordagem mais ampla do fenômeno. Nesta época, a gerontologia se restringia praticamente aos aspectos biológicos do envelhecimento e da velhice. Somente mais tarde, na década de 1930 é que Marjory Warren começou a delinear os princípios de uma avaliação multidimensional e a importância da interdisciplinaridade (Papaléo Netto, 2011).

Durante décadas, a geriatria teve um peso maior que as demais áreas que compõem a gerontologia, isto devido aos avanços dos estudos na área. Este fator, aliado à dificuldade da gerontologia em se firmar como disciplina ou ciência e à resistência dos profissionais na realização de investigação com caráter interdisciplinar foram os principais aspectos que geraram um atraso na construção do conhecimento em gerontologia (Papaléo Netto, 2011). 
Segundo Lopes (2000), foi a partir dos anos 40 que a gerontologia buscou a ampliação de seus limites, assumindo seu caráter multidisciplinar, com uma identidade coletiva, abordando também os aspectos psicológicos e sociais da velhice. De acordo com a mesma autora, foi

graças aos investimentos multidisciplinares da Gerontologia, a partir da segunda metade do século $X X$, sua definição atual é mais abrangente, tendo em vista o âmbito de suas pretensões no começo do século (Lopes, 2000, p.25).

Desta maneira, visão abrangente da atenção à saúde do idoso hoje é uma atribuição da gerontologia. A ciência do envelhecimento tem como fundamento o estudo deste fenômeno sob uma ótica basicamente interdisciplinar. (Papaléo Netto, 2011). O mesmo autor, ainda destacou:

É essa peculiaridade que torna a Gerontologia, em todos os seus campos de atuação, como assistência à saúde, pesquisa e ensino, diferente de outras áreas de conhecimento científico. De fato, são estas características que tornam a interdisciplinaridade obrigatória para o estudo de um fenômeno multifacetado em seus aspectos e multifatorial em sua gênese (Papaléo Netto, 2011; pag. 9).

Então, a partir da participação de profissionais de diversas áreas na atenção à saúde do idoso e na pesquisa e ensino em gerontologia, coloca-se em prática a recomendação da Organização Pan-Americana de Saúde (OPAS), que determina que:

quaisquer que sejam as atividades de promoção planejadas de saúde, deverão incluir atuações no campo biológico, psicossocial, político e legal, e que a promoção de saúde do idoso deverá estar a cargo de uma equipe interdisciplinar (Papaléo Netto, 2011, p.12). 
Nessa abordagem, ao pensar a Gerontologia, mais especificamente no campo da saúde, é de suma importância pensar que os gastos neste setor tendem aumentar progressivamente com o envelhecimento populacional, agravando os desafios de promoção da equidade na saúde.

Frente a isso, surge a questão levantada por Motta e Aguiar (2007), de como cuidar da parcela mais necessitada desta população de idosos, com maiores comorbidades, e maior incapacidade, por meio de abordagem diagnóstica, terapêutica e de reabilitação adequadas? Segundo estes autores, grandes gastos não garantem, em si, a melhoria da qualidade de vida dos idosos, sendo necessário trabalhar para a mudança nos princípios que regem a atenção à sua saúde. Assim, o aumento da expectativa de vida traz como consequência uma necessidade de mudança no modelo clínico-assistencial e na formação profissional (Motta; Aguiar, 2007).

\subsection{A formação de profissionais para atuar com idosos}

Segundo Cachioni e Neri (2004), o termo gerontologia educacional foi definido por David Peterson em 1976 como a área responsável pelo estudo e pela prática das tarefas de ensino a respeito e orientadas a pessoas envelhecidas e em processo de envelhecimento. Mais tarde, o mesmo autor acrescentou que se tratava da tentativa de aplicar o que se conhece sobre a educação e o envelhecimento em benefício da melhoria da vida dos idosos, fazendo uma classificação dos seus conteúdos em três partes: educação para os idosos; educação para a população em geral sobre a velhice; formação de recursos humanos para o trabalho com os idosos (Cachioni; Neri, 2004). 
Nessa linha de pensamento, tomaremos nesta discussão a perspectiva da formação de recursos humanos para o trabalho com idosos, que, de acordo com Neri (2014), citando novamente Peterson,

ocorre por meio da formação de pesquisadores e da capacitação de profissionais para atuar nos campos social, da atenção à saúde, da gestão de serviços, organizações e instituições e das políticas públicas (NERI, 2014, p. 199).

Tal formação profissional em gerontologia é composta por diferentes atividades, como podemos citar abaixo:

atividades voltadas para a aquisição de conhecimentos, capacidades, atitudes, comportamentos e competência profissional necessários para tratar das questões da velhice e do envelhecimento. Esta formação compreenderia também a qualificação profissional acumulada pelos profissionais que atuam na área gerontológica, como por exemplo, sua experiência prática (MARTINS de SÁ, 2011, p.1680).

O objetivo desta formação é proporcionar e atualizar conhecimentos na área de Geriatria e Gerontologia. Esta formação pode se dar por diferentes meios, dentro de uma perspectiva formal e não formal, distribuídos da seguinte forma: formal, compreende os cursos de extensão universitária, de pós-graduação latu-sensu (especialização) e stricto-sensu (mestrado e doutorado) e de graduação em Gerontologia; não formal, compreende a aquisição de conhecimento na área que acontece em seminários, congressos, simpósios, minicursos e eventos (Martins de Sá, 2011).

Tomando ainda como referência o trabalho de Martins de Sá (2011), apresentamos as características do perfil desejado para o profissional que atua em geriatria e gerontologia, que, de acordo com a autora, necessita:

- Apreender histórica e criticamente o processo do envelhecimento, em uma perspectiva de totalidade;

- Compreender o significado social da ação gerontológica; 
- Situar o desenvolvimento da gerontologia no contexto sócio histórico internacional, nacional e local;

- Atuar nas expressões da questão da velhice e do envelhecimento, formulando e implementando propostas para o seu enfrentamento;

- Realizar pesquisas que subsidiem a formulação de ações gerontológica;

- Compreender a natureza interdisciplinar da gerontologia, buscando ações compatíveis na área do ensino, da pesquisa e da prestação de serviços;

- Estar aberto à mudança, agindo com criatividade;

- Zelar por uma postura ética e solidária no desempenho das ações gerontológicas;

- Orientar a população idosa na identificação de recursos para atendimento das suas necessidades básicas e defesa de seus direitos;

- Ter competência teórico-crítica, técnico-operativa e ético-política para uma ação gerontológica que atenda aos requisitos da eficiência, eficácia e efetividade.

Assim, este profissional deve ser capaz de compreender o ser velho e o processo de envelhecimento em todas as suas dimensões, além de desenvolver e aplicar novas propostas que contemplem as questões gerontológicas atuais, de maneira eficiente, eficaz e efetiva. (Martins de Sá, 2011). E a interdisciplinaridade deve ser o fio condutor da formação destes profissionais (Cachioni; Neri, 2004).

Trazendo uma perspectiva internacional, o relatório seminal da Institute of Medicine's dos Estados Unidos, chamado de "Retooling for an Aging America", no ano de 2008, afirmou que a simples expansão da capacidade dos sistemas atuais de saúde não seria suficiente para alcançar as necessidades da população de idosos, 
sendo fundamental o treinamento e formação adequados dos profissionais de saúde para prestarem um cuidado de qualidade e eficiente a estes idosos. Dentre as características que devem ser desenvolvidas nestes profissionais, o documento enfatizou a colaboração interdisciplinar, competências em geriatria e gerontologia e integração dos diferentes serviços de atendimento ao idoso (Barker et al, 2011).

Também, a Política Nacional de Saúde da Pessoa Idosa (Brasil, 2006) discorreu sobre a necessidade de formação de profissionais para atuarem com envelhecimento, abordando os aspectos necessários, como a formação e educação permanente dos profissionais de saúde do SUS na área de saúde da pessoa idosa, a inclusão nos currículos escolares de disciplinas que abordem o processo do envelhecimento, a adequação de currículos, metodologias e material didático de formação de profissionais na área da saúde, visando ao atendimento das diretrizes fixadas na Política e a capacitação de equipes multiprofissionais e interdisciplinares, visando à qualificação contínua do pessoal de saúde nas áreas de gerência, planejamento, pesquisa e assistência à pessoa idosa.

Porém, existem muitas barreiras na implantação de tais exigências, pois, mesmo com os esforços de muitas entidades, tais mudanças ainda não estão conseguindo acompanhar as demandas da população brasileira. (Galera, 2011; Xavier, Koifman, 2011). Isto se deve principalmente à falta de profissionais habilitados ao ensino de geriatria e gerontologia, por questões burocráticas

ou pela noção errônea de que não há a necessidade de abordagem específica para esta população, retardando mais ainda o ideal de atingir os objetivos originais e piorando a deficiência de profissionais voltados para a área (GALERA, 2011, p.189).

$\mathrm{Na}$ apresentação dos resultados deste trabalho, daremos continuidade à discussão sobre formação dos profissionais participantes do estudo que compõem a equipe gerontológica. 


\subsection{A equipe gerontológica}

No cuidado ao idoso é essencial considerar os múltiplos aspectos da saúde e funcionalidade, o que requer a participação de uma equipe de profissionais que deverá prestar um cuidado amplo e compreensivo a esta população (Gold et al, 2012).

Estes profissionais precisam ser capacitados e exibirem características importantes para a atuação com este público. Dentre elas, podemos destacar: possuírem competências culturais, serem comprometidos com a melhoria contínua, terem conhecimentos clínicos, serem capazes de trabalhar em equipe, conhecerem o processo de envelhecimento e a diversidade da população idosa, incluindo variáveis socioeconômicas e redes de serviços para idosos (Takamur, 2007). Outras características essenciais para prestar um bom atendimento ao idoso, são: ter habilidades e conhecimento de diagnósticos e doenças, boa comunicação com o idoso e seus familiares, trabalhar bem em equipe, manter aprendizado contínuo e aplicar novos conhecimentos na prática (Reuben, 2002).

Nessa linha de pensamento, evidencia-se que o cuidado ampliado ao idoso envolve a participação de uma equipe interdisciplinar, com uma visão holística do paciente, abrangendo aspectos clínicos, psicossociais e ambientais. Os objetivos desta equipe implicam oferecer serviços de qualidade para os idosos, por meio de abordagens efetivas que alcancem todas as suas demandas. Esta abordagem também precisa ser flexível e adaptável às necessidades desta clientela, tendo como meta final a melhora da qualidade de vida da pessoa idosa (Telles; Borges, 2010; Volland; Wrigh, 2011).

Frente a isso, o diálogo e a comunicação tornam-se elementos imprescindíveis para a integração e a articulação entre os membros da equipe. Os dados devem ser compartilhados como meio de generalizar as informações e estabelecer as relações 
entre fatores biológicos, emocionais e sociais dos casos acompanhados. Assim, a equipe pode compartilhar os objetivos para atender todas as necessidades e definir como as diferentes disciplinas trabalharão juntas para chegar aos resultados esperados. Desta forma, as intervenções podem ser colocadas em prática, individualmente ou em colaboração, de acordo com o necessário, e os progressos podem ser avaliados. A partir destas novas avaliações, discussões podem ocorrer com a equipe para rever os objetivos propostos ou sugerir outras intervenções (Zeiss; Steffen,1996).

De acordo com Zeiss e Steffen (1996), este grupo de profissionais toma a responsabilidade sobre a efetividade do serviço e das funções da equipe. As funções de liderança devem ser compartilhadas entre os membros, com a expectativa de que todos devem se comprometer igualmente, sem que haja hierarquia na organização da equipe. De acordo com os mesmos autores:

Por demandar um alto grau de colaboração e decisões consensuais, os membros da equipe devem ter grandes habilidades interpessoais. A equipe também precisa dedicar um tempo para desenvolver estratégias efetivas de trabalho e dar especial atenção ao processo de trabalhar em conjunto, bem como aos resultados do trabalho da equipe. Habilidades de comunicação, desenvolvimento de papéis, habilidade de liderança, de resolução de problemas, visão abrangente dos casos são características necessárias a todos os membros da equipe (Zeiss; Steffen, 1996, p. 427).

Mesquita et al., citando Aboim e Sayeg (2011), também frisaram algumas características necessárias aos profissionais que atuam com idosos: atuação interdisciplinar; conduta ética; atenção integral à pessoa idosa em função do seu ambiente, família e comunidade; avaliação de sinais e sintomas de doenças e de incapacidades, os fatores de risco e seu controle; familiaridade com as ações de 
prevenção, recuperação e reabilitação; avaliação cuidadosa para o uso de medicamentos e novas substâncias; promoção da estimulação motora e cognitiva dos idosos; participação em ações de educação continuada; zelo pela preservação da qualidade de vida, autonomia e dignidade da pessoa idosa (Mesquita et al, 2011).

O trabalho em equipe gerontológica possui inúmeras vantangens, dentre as quais podemos destacar: melhor custo benefício, pois traz os melhores resultados no tratamento; redução das ações duplicadas; melhor percepção das necessidades do idoso; intervenções mais variadas e criativas; redução de custos institucionais, aumento da satisfação dos profissionais (Zeiss; Steffen,1996).

A equipe interdisciplinar é pensada para o cuidado continuado de doenças crônicas e problemas complexos, mas não é organizada para dar respostas rápidas em situações de crise. Portanto, não é necessário que todas as equipes tenham todos os profissionais. Elas podem ser organizadas de acordo com as demandas atendidas. Lembrando que uma equipe só se torna interdisciplinar se os próprios membros aceitarem o modelo e decidirem assumir as responsabilidades conjuntamente. $O$ coordenador da equipe pode estimular o desenvolvimento destas pessoas, mas nunca de maneira autoritária, pois autoridade e interdisciplinaridade não funcionam juntas (Zeiss; Steffen,1996).

A equipe interdisciplinar pode contribuir para o atendimento integral do idoso, preconizado nas políticas públicas e destacado na literatura, tema que apresentaremos a seguir. 


\subsection{O atendimento integral do idoso}

O processo de envelhecimento é caracterizado por múltiplos aspectos, o que torna essencial uma abordagem multidimensional à saúde da pessoa idosa, colocando em prática o que é preconizado pela Organização Mundial de Saúde. Este tipo de abordagem visa a melhora da qualidade de vida do idoso e torna essencial a participação de vários profissionais (Papaléo Netto, 2011).

O envelhecimento populacional desafia a habilidade de produzir políticas de saúde que respondam às necessidades dos idosos. A Constituição Brasileira incorpora uma concepção ampliada de saúde, o que possibilitou novas reflexões para o campo.

A saúde é direito de todos e dever do Estado, garantido mediante políticas sociais e econômicas que visem à redução do risco de doença e de outros agravos e ao acesso universal e igualitário às ações e serviços para sua promoção, proteção e recuperação. Art. 196 (Brasil, 1988).

Ainda, no artigo 198, a Constituição aborda a questão da necessidade do atendimento integral, dentre outros aspetos, explicitando a importância e a relevância deste tipo de abordagem na saúde (Brasil, 1988).

Nos anos seguintes, é criada a Lei Orgânica da Saúde (8080/90), que explicita em seu artigo $7^{\circ}$ o caráter integral da assistência (Brasil, 1990). Desde então, o conceito de integralidade vem sendo objeto de reflexão na literatura em Saúde. Motta e Aguiar (2007) relataram que podemos conferir ao termo, três conjuntos de sentido: o atributo das práticas dos profissionais de saúde, o atributo da organização dos serviços e o de resposta governamental via políticas voltadas para grupos populacionais específicos. Os autores ressaltaram ainda, que para avançar na direção 
da integralidade é importante identificar os obstáculos nos tratamentos oferecidos à população idosa.

Em 1994 foi promulgada a Lei 8.842, que dispõe sobre a Política Nacional do Idoso, que tem por objetivo assegurar os direitos sociais do idoso, criando condições para promover sua autonomia, integração e participação efetiva na sociedade. Entre outros aspectos, este instrumento determina a inclusão da geriatria e gerontologia como disciplinas curriculares nos cursos superiores, a garantia da assistência de saúde ao idoso, nos diferentes níveis e com diferentes ações, e as parcerias entre as Secretarias de Saúde dos diferentes estados com os Centros de Referência em atendimento ao idoso para a formação e treinamento de equipes interprofissionais.

A Política Nacional de Saúde da Pessoa Idosa, criada em 1999 foi revista e atualizada em 2006, evidencia como um dos grandes diferenciais, a orientação dos serviços públicos de saúde, que deve identificar o nível de dependência do idoso e atribuir um acompanhamento diferenciado para cada situação. Tal política determina que a prática de cuidados às pessoas idosas exige abordagem global, interdisciplinar e multidimensional, que considere a grande interação entre os fatores físicos, psicológicos e sociais que influenciam a saúde dos idosos e a importância do ambiente no qual está inserido (Brasil, 2006).

Nessa abordagem, a condição funcional do idoso é o fator norteador para as ações de atenção primária, de prevenção e de reabilitação, para a recuperação da máxima autonomia funcional, prevenção do declínio funcional e recuperação da saúde (Motta; Aguiar, 2007).

Também, o Estatuto do Idoso, aprovado em 2003, em seu capítulo IV, Art. 15, afirma que deve ser assegurada a atenção integral à saúde do idoso. 
O princípio da integralidade ressalta a importância do trabalho com a abordagem interdisciplinar, o

que favorece a ampliação e o desenvolvimento da dimensão cuidadora, o atendimento contextualizado dentro da realidade de cada usuário ou comunidade e um maior comprometimento dos profissionais com o seu trabalho (Lemos, et al, 2012, p.4).

Como consequência, pode haver quebra das relações de poder entre os profissionais da saúde e a disseminação do trabalho colaborativo em equipe (Lemos, et al., 2012).

Para Câmara et al. (2016), o trabalho em equipe no Brasil ainda tem um longo caminho pela frente para se consolidar como uma prática eficaz, superando o tradicional processo de trabalho fragmentado. O debate sobre este tipo de trabalho sempre esteve presente no processo de formação em saúde. De modo geral, esse debate esteve mais centrado no campo teórico do que na efetivação de processos de ensino e aprendizagem capazes de formar profissionais mais aptos à colaboração no trabalho em equipe (Costa, 2016).

Assim, a atenção interdisciplinar e interprofissional pressupõe o trabalho em equipe. 


\section{Interdisciplinaridade e interprofissionalidade: do desafio conceitual ao desafio prático}

Traçaremos abaixo um esclarecimento conceitual sobre interdisciplinaridade e interprofissionalidade. Conceitos estes que aparecem com diferentes definições na literatura, muitas vezes, de maneira misturada, e se confundem nos diálogos dos profissionais de saúde. Tal esclarecimento se torna importante para a discussão das falas coletadas neste estudo.

\subsection{Interdisciplinaridade}

O conceito de interdisciplinaridade surgiu no século $X X$, contudo só a partir da década de 60, começou a ser enfatizado como necessidade de transcender e atravessar o conhecimento fragmentado. Nesse passo, a interdisciplinaridade pode, hoje, ser compreendida como a manifestação da evolução do pensar e da inquieta versatilidade do espírito humano, radicando-se em nosso modo de ver a realidade (Coimbra, 2000).

O olhar interdisciplinar se justifica na prestação de serviços de saúde gerontológica, haja vista que todas as áreas do conhecimento e todas as ciências são igualmente importantes para a compreensão do homem em qualquer fase do ciclo vital, do mundo, do ambiente físico e sociocultural e de todos os fenômenos que caracterizam a vida humana; nas suas mais diversas fases. O profissional por si só pode ser interdisciplinar, usando em sua atuação conhecimento de diferentes áreas. Para ser interdisciplinar, o profissional deve ser capaz de se colocar em outros 
contextos, extrapolando a sua área de formação. Assim, ele pode ter um entendimento da complexidade do fenômeno que é seu objeto de estudo (Jantsch; Bianchetti, 2011).

Para Mueller e colaboradores (2011), atualmente algumas características são esperadas dos profissionais que pretendem ingressar no mercado de trabalho, sendo algumas delas a capacidade de trabalhar em equipe, a abertura para trocas, sociabilidade, colaboração e comunicação permanente.

Destacamos, a flagrante necessidade de considerar o ponto de convergência dos conhecimentos, elemento essencial para a efetivação da interdisciplinaridade, tão significativa na melhoria dos serviços de saúde dispensados aos idosos (Lodovici; Silveira, 2011).

Minayo (2010) avaliou que a interdisciplinaridade na saúde só pode ser construída a partir de uma visão sócio filosófica que faça crítica ao fragmentário e à visão funcionalista tradicional, mas que também consiga criar uma proposta epistemológica com axiomas comuns a um conjunto de disciplinas.

Rodrigues afirmou que a interdisciplinaridade:

É compreendida como método, técnica didática, instrumento de ação, mas principalmente, (...) como postura profissional que permite se pôr a transitar o 'espaço da diferença' com sentido de busca, de desvelamento da pluralidade de ângulos que um determinado objeto investigado é capaz de proporcionar, que uma determinada realidade é capaz de gerar, que diferentes formas de abordar o real podem trazer. (...) A perspectiva interdisciplinar não fere a especificidade das profissões e tampouco seus campos de especialidade. (...) Sob este ângulo, a interdisciplinaridade não pretende a unidade de conhecimentos, mas a parceria e a mediação dos conhecimentos parcelares, na criação de saberes (Rodrigues, 2000) (online).

Camacho (2002), por sua vez, retratou a Gerontologia como área rica e cheia de lacunas a serem preenchidas pelas disciplinas que a compõem, indo além das 
abordagens convencionais da clientela idosa. A autora destacou a importância da Gerontologia na atuação interdisciplinar, ressaltando o idoso no contexto social. A interdisciplinaridade se torna o instrumento condutor para Gerontologia em busca de mudanças que venham a somar conhecimentos e redundar em esforços no processo de desenvolvimento da área da saúde em relação ao senescente.

Justamente por isso, diversos autores falaram da relevância e da necessidade da interdisciplinaridade na prática gerontológica (Camacho, 2002; Minayo, 2010; Lodovici; Silveira, 2011). É nessa linha que Lodovici e Silveira (2011) tomaram a interdisciplinaridade também como uma proposta metodológica facilitadora da articulação e integração entre conhecimentos de diferentes áreas, especialmente na gerontologia, cujo objeto exige este tipo de abordagem.

Para Fazenda (1979), por sua vez, pensar, construir e agir interdisciplinarmente constitui-se numa busca constante e coletiva na direção de uma sociedade mais humana para todos os segmentos sociais, incluindo as pessoas idosas.

Neste sentido, torna-se relevante a análise da percepção destes profissionais acerca da interdisciplinaridade e interprofissionalidade. Considerando-se, principalmente, a possibilidade destas percepções influenciarem de maneira indireta na postura destes profissionais durante os serviços prestados aos idosos, o que pode gerar diferentes impactos na qualidade dos serviços de saúde oferecidos a esta população.

\subsection{Interprofissionalidade}

Alguns estudos demonstraram que dentre as diferentes categorias profissionais predomina a tendência em satisfazer aspirações e manter sua autonomia, em detrimento da colaboração profissional (Furtado, 2009; Ellery, 2012). 
Pensando em garantir uma reserva de mercado, o profissionalismo constitui-se na história como estratégia de retenção do conhecimento, buscando torná-lo o mais específico possível, permanecendo acessível a poucos (Furtado, 2009).

Sabemos que para se chegar a uma prática interprofissional, deve-se estabelecer uma nova concepção de trabalho que admite a diversidade de ação, busque constantemente o consenso e fundamenta-se na interdisciplinaridade. Desse modo, o trabalho interprofissional passa a significar também a possibilidade da prática do profissional se reconstruir na prática do outro, transformando ambas na intervenção do contexto onde estão inseridas (Araújo; Rocha, 2007).

Nessa abordagem, o trabalho interprofissional pressupõe novas formas de relacionamento, tanto no que diz respeito à hierarquia institucional, à gestão, à divisão e à organização do trabalho, quanto no que diz respeito às relações que os trabalhadores estabelecem entre si e com os usuários do serviço (Matos, 2010).

Assim, é essencial que o profissional envolvido em práticas interprofissionais encontre, no trabalho com outros agentes, elementos para a (re)discussão do seu lugar e descubra, nos debates com outros membros da equipe de saúde, os conteúdos passíveis de uma atuação interprofissional (voltada ao idoso), contribuindo com os conhecimentos do seu âmbito interventivo.

Dessa maneira, inexiste receita pré-estabelecida para determinar um trabalho interprofissional, mas certamente uma atitude necessária para esta prática, que envolva o pensar e o agir rompendo hábitos e comodismos. Sobretudo, considerandose que a prática interprofissional é essencialmente coletiva, supondo integração, troca, reciprocidade e engajamento para superar a fragmentação e o isolamento.

Embora se fale incessantemente da interdisciplinaridade e interprofissionalidade, muitas são as dificuldades de seu exercício na prática dos 
serviços de saúde. Os profissionais se deparam com um desafio: propiciar que múltiplas áreas do saber, com diferentes propostas de trabalho e diversas formas de atuação, possam agir conjuntamente sem que se instale obrigatoriamente um esquema hierárquico, mas que, por outro lado, as ações sejam planejadas e executadas segundo um código de ética e de organização comum a todos os integrantes (Jacob Filho, 2011).

Miller (2004) afirmou, principalmente em razão disto, que o funcionamento efetivo de uma equipe depende de fatores como: os profissionais envolvidos; o relacionamento da equipe com outros profissionais e outras equipes e o equilíbrio da instituição da qual a equipe faz parte. Cada membro da equipe deve, nesta compreensão, entender que é parte de um sistema maior.

Assim, os profissionais podem compreender a natureza humana como também a natureza das organizações, o que já é o começo para uma acurácia na identificação dos problemas, na escolha de estratégias válidas de intervenção e na resolução mais efetiva e eficiente dos problemas (Miller, 2004).

Podemos afirmar, seguramente, que podem existir situações em que os profissionais integrantes das equipes de saúde são atropelados pela emergência em dar respostas às demandas e se furtam, por isso mesmo, do privilégio da reflexão. Daí a relevância em manter acesa e renovada a discussão sobre interdisciplinaridade, considerando a vinculação entre a atual política de saúde, norteada pelo princípio de integralidade e o exercício profissional - cujos modelos ainda permanecem conectados às práticas que oscilam entre o uni e o multidisciplinar.

É notório que a interprofissionalidade só é realizada por meio da intencionalidade, baseada no plano institucional, que pode fomentá-la com políticas e projetos, mas também, e principalmente, com o desejo de cada profissional de aderir 
a esses projetos e de se engajar na construção da prática coletiva. Isto, porque a postura interprofissional exige trocas entre os profissionais e a abertura para questionar e ser questionado imbuído de respeito e reconhecimento mútuos.

Papaléo Netto (2011) destacou que é preciso que se comece a exercer a interdisciplinaridade pela busca de um idioma comum a todos os profissionais que atuam em gerontologia, pois o uso de termos e expressões de diferentes áreas pode gerar confusão na equipe interprofissional.

Para Furtado (2009) transpor a discussão da interdisciplinaridade para o campo das práticas em saúde é enfrentar o antagonismo entre a diferenciação (que buscamos ativamente pela formação profissional) e a integração (requerida pela colaboração interprofissional e condição para qualificação da clínica).

Assim, com os resultados deste estudo temos um grande desafio que é colaborar no sentido de propiciar mudanças no processo de trabalho em saúde que favoreçam tanto a interdisciplinaridade quanto a interprofissionalidade visando a melhoria da qualidade assistencial prestada à população idosa. 


\section{Objetivo}

A questão que surge a partir de tais reflexões é se os profissionais que atuam na atenção à saúde do idoso reconhecem e valorizam a necessidade da interdisciplinaridade e da interprofissionalidade nos cuidados oferecidos a esta população e de que maneira eles as vivenciam em seu cotidiano de atendimento ao idoso. Neste sentido, a presente pesquisa tem como objetivo geral analisar a percepção de profissionais, de diferentes formações, que atuam em um serviço de saúde para idosos, acerca da interdisciplinaridade e interprofissionalidade. 


\section{Materiais e Métodos}

Trata-se de uma pesquisa aplicada, exploratória, descritiva, de caráter qualitativo, que coletou dados sobre a percepção dos profissionais de uma equipe gerontológica de ambulatório de nível secundário, a respeito da interdisciplinaridade e interprofissionalidade, baseando-se no conceito e nos aspectos apresentados na ampla bibliografia do tema e julgados como relevantes para o pensamento interdisciplinar e para a prática interprofissional.

A amostra foi composta por profissionais das seguintes áreas: medicina, fisioterapia, terapia ocupacional, fonoaudiologia, educação física, nutrição, psicologia, serviço social, odontologia e enfermagem, que atuam no atendimento clínico da instituição escolhida para a coleta de dados, que será apresentada a seguir.

\subsection{Local e procedimentos da coleta dos dados}

O local escolhido para a coleta de dados foi o Centro de Referência do Idoso da Zona Norte (CRI Norte). Inaugurado em 17 de fevereiro de 2005, é uma parceria entre a Secretaria de Estado da Saúde de São Paulo e a Organização Social de Saúde Associação Congregação de Santa Catarina. O CRI Norte é um ambulatório de atenção secundária do Sistema Único de Saúde (SUS) especializado na atenção à saúde ao idoso. O atendimento é referência para as Unidades Básicas de Saúde (UBS) da região norte da cidade de São Paulo.

Tem como missão prestar assistência interdisciplinar ambulatorial à pessoa idosa, por meio de ações de prevenção, diagnóstico, terapia, reabilitação e de atividades do Centro de Convivência, potencializando o envelhecimento ativo. Além de realizar a gestão de doenças crônicas não transmissíveis, propondo modelos 
inovadores de assistência à saúde e contribuir na construção e fortalecimento das políticas públicas voltadas ao envelhecimento populacional. Seus objetivos são:

- Prestar atendimento ambulatorial secundário aos idosos referenciados das Unidades Básicas de Saúde e Serviços de Saúde da Zona Norte. - Ofertar vagas de atendimento médico - assistencial e Serviço de Apoio Diagnóstico conforme a demanda de rede da saúde através da oferta de vagas da Central de Regulação e Oferta de Serviços de Saúde (CROSS).

- Participar de implantação de políticas públicas da pessoa idosa advindas da $\begin{array}{lllll}\text { Secretaria do } & \text { Estado } & \text { Saúde }\end{array}$

- Capacitar as redes de atenção à saúde (RAS) do Sistema Único de Saúde e a comunidade aos cuidados da pessoa idosa.

O atendimento ambulatorial é integrado e composto por: atendimento médico e equipe multiprofissional, exames (Serviço Auxiliar de Diagnóstico e Terapia SADT), cirurgia menor ambulatorial (CMA) e Centro de Convivência. Atualmente o CRI Norte conta com uma equipe de 186 colaboradores, 108 voluntários idosos, 7 médicos celetistas e 60 médicos prestadores (consultas e exames) e 28 prestadores de serviço.

A instituição também possui um Centro de Convivência, que tem uma programação diversificada de oficinas que são ensinadas por voluntários idosos. Tem o objetivo de promover atividades contemplando os pilares do Envelhecimento Ativo proposto pela Organização Mundial de Saúde (OMS) com atividades físicas, atividades educativas, atividades culturais, atividades manuais e de geração de renda e atividades temáticas.

O CRI Norte por ser um serviço de referência em saúde do idoso, atua também como centro capacitador na área de geriatria e gerontologia, apoiando as ações 
advindas da Secretaria do Estado de Saúde. A instituição tem o compromisso em capacitar a rede de atenção básica para otimizar o atendimento prestado à população idosa por meio de e aulas ministradas para profissionais de saúde e comunidade.

Os dados foram coletados na instituição com as seguintes etapas:

1 - Aplicação de questionário (Apêndice A): os participantes foram reunidos em uma sala na instituição selecionada, onde foram explicados os objetivos da pesquisa. O questionário foi constituído por perguntas abertas a respeito da compreensão sobre interdisciplinaridade e interprofissionalidade, além da formação profissional. Os participantes que não puderam estar presentes neste momento receberam o questionário e Termo de Consentimento Livre e Esclarecido posteriormente, tendo o prazo de 15 dias para devolvê-los preenchidos para a pesquisadora.

2 - As respostas dos questionários foram analisadas e foram estabelecidas as perguntas norteadoras para o grupo focal.

3 - Grupo focal: foi realizado encontro com 12 dos participantes que concordaram em participar da pesquisa e puderam estar presentes na data e horário estabelecidos, onde foi discutido o tema interdisciplinaridade e interprofissionalidade na percepção de cada um e do grupo. A pesquisadora participou como moderadora do grupo, que contou com um observador mudo, que fez as anotações sobre o debate. As falas dos participantes foram gravadas e transcritas posteriormente. O roteiro utilizado no grupo focal pode ser lido no Apêndice C. Algumas falas selecionadas do grupo focal podem ser lidas no Anexo C.

Grupos focais são uma técnica de pesquisa que coleta dados por meio das interações grupais ao se discutir um tópico especial sugerido pelo pesquisador. Como técnica, ocupa uma posição intermediária entre a observação participante e as entrevistas em profundidade. Pode ser caracterizado também como um recurso para 
compreender o processo de construção das percepções, atitudes e representações sociais de determinados grupos (Gondim, 2003).

\subsection{Análise dos dados coletados}

A análise dos dados foi realizada por meio da técnica de análise de conteúdo proposta por Minayo (2010). A análise de conteúdo, enquanto método, torna-se um conjunto de técnicas de análise das comunicações que utiliza procedimentos sistemáticos e objetivos de descrição do conteúdo das mensagens. Na visão desta autora, constitui-se na análise de informações sobre o comportamento humano, possibilitando uma aplicação bastante variada, e tem duas funções: verificação de hipóteses e/ou questões e descoberta do que está por trás dos conteúdos manifestos. Tais funções podem ser complementares, com aplicação tanto em pesquisas qualitativas como quantitativas.

Suas técnicas de pesquisa permitem a descrição das mensagens e das atitudes atreladas ao contexto da enunciação, bem como as inferências sobre os dados coletados. A escolha deste método de análise pode ser explicada pela necessidade de ultrapassar as incertezas das hipóteses e pressupostos, pela necessidade de enriquecimento da leitura por meio da compreensão das significações e de descobrir as relações que se estabelecem além das falas propriamente ditas (Cavalcante et al, 2014).

Para a análise do material, a técnica parte de uma leitura de primeiro plano do material coletado, para atingir um nível mais profundo, ultrapassando os sentidos manifestos no material. Os processos, no geral, levam a relacionar estruturas semânticas (significantes) com estruturas sociológicas (significados) das falas e 
articular os achados com fatores que podem estar relacionados, como variáveis psicossociais, contexto cultural e processo de produção do material textual (Minayo, 2010). Durante a etapa da exploração do material, o investigador busca encontrar categorias, em função das quais o conteúdo de uma fala será organizado. A categorização consiste num processo de redução do texto às palavras e expressões significativas (Cavalcante et al, 2014). A partir daí o pesquisador propõe inferências e realiza interpretações, inter-relacionando-as com o quadro teórico ou abrindo caminhos em torno de novas dimensões teóricas e interpretativas, sugeridas pela leitura do material, o que permite uma ampliação da proposta teórica inicial (Minayo, 2010).

\subsection{Aspectos éticos}

Esclarecemos que todos os participantes que concordaram em participar da pesquisa assinaram o Termo de Consentimento Livre e Esclarecido (Apêndice B). Haverá a garantia da preservação da privacidade, confidencialidade dos dados e do anonimato dos participantes respeitando-se as diretrizes da Resolução 466/12 Do Conselho Nacional de Saúde - Ministério da Saúde relacionada aos preceitos éticos em Pesquisa em seres humanos. O presente trabalho obteve aprovação do Comitê de Ética em Pesquisa em seres humanos da EACH USP sob o CAAE57303616.7.0000.5390. (Anexo B)

Salientamos que a realização do trabalho obteve autorização da instituição escolhida para a coleta dos dados. (Anexo A) 


\section{Resultados}

Apresentaremos a seguir a descrição dos resultados obtidos nesta investigação. Foram abordados 30 profissionais de saúde da instituição e convidados para participação no estudo. No total, concordaram em participar da pesquisa 21 profissionais, que serão denominados neste estudo a partir da letra "P" e o número correspondente de seu questionário, como forma de preservar a identidade dos profissionais (Por exemplo: P1 = participante com questionário número um).

Apresentaremos a descrição do perfil destes participantes, bem como as características de sua formação profissional, somados às suas vivências cotidianas em relação à interdisciplinaridade e interprofissionalidade.

\subsection{Perfil dos participantes do estudo}

Os profissionais participantes do estudo eram das seguintes categorias: enfermagem, fisioterapia, terapia ocupacional, fonoaudiologia, nutrição, psicologia, odontologia, serviço social, educação física e medicina, distribuídos conforme a tabela 1. A amostra contou com 17 participantes do sexo feminino e quatro do sexo masculino. A idade média dos participantes foi de 34 anos (variando de 24 a 50 anos) e eles tinham em média 8,7 anos de formação, porém esta formação variou de dois anos até 22 anos, o que demonstra que a amostra era formada por profissionais com tempos de experiência bem diversificados. 
Tabela 1 - número de participantes por áreas de graduação.

\begin{tabular}{lc}
\hline Graduação & $\mathbf{n}$ \\
\hline Enfermagem & 2 \\
Fisioterapia & 4 \\
Terapia Ocupacional & 3 \\
Fonoaudiologia & 1 \\
Nutrição & 2 \\
Psicologia & 3 \\
Odontologia & 1 \\
Serviço Social & 2 \\
Educação Física & 1 \\
Medicina & 2 \\
TOTAL & $\mathbf{2 1}$ \\
\hline
\end{tabular}

Destes participantes, $76 \%$ cursaram sua graduação em universidades privadas. Em relação ao tempo de experiência na atuação gerontológica, este foi em média de sete anos.

Em relação a cursos de pós-graduação, 95\% dos participantes fizeram algum curso (variando de 0 a 3 cursos por profissional), sendo que $89 \%$ dos cursos de pósgraduação mencionados foram cursos latu sensu (especialização, aprimoramento ou extensão) e $11 \%$ foram cursos de pós-graduação strictu senso (mestrado ou doutorado). É possível observar na tabela 2 que a maioria dos cursos mencionados pelos participantes se concentrou na área de Geriatria e Gerontologia. 
Tabela 2 - número de cursos realizados segundo áreas de pós-graduação

\begin{tabular}{lc}
\hline \multicolumn{1}{c}{ Áreas de pós-graduação } & $\mathbf{n}$ \\
\hline Geriatria e Gerontologia & 12 \\
Reabilitação & 9 \\
Neuropsicologia/Psicologia clínica & 5 \\
MBA em gestão hospitalar & 2 \\
Urgência e emergência & 2 \\
Outros & 9 \\
\hline
\end{tabular}

A partir dos dados, é possível observar que se tratou de uma amostra de profissionais diversificada em relação à idade, tempo de formação e tempo de experiência no trabalho com idosos.

Iniciaremos a apresentação do contato que estes profissionais tiveram com a interdisciplinaridade e interprofissionalidade e com conteúdos sobre envelhecimento durante sua formação acadêmica e profissional. Optamos por apresentar também algumas falas destes profissionais, tanto do questionário quanto do grupo focal, que ilustram as categorias apresentadas.

6.1.1 Acesso a conteúdos sobre envelhecimento na graduação e pós-graduação

Durante o grupo focal, os participantes do estudo iniciaram um debate sobre o acesso a conteúdos de geriatria e gerontologia em sua formação acadêmica. Foi possível perceber que eles tiveram diferentes aproximações com o tema, sendo que alguns mencionaram ter tido pouco ou nenhum conteúdo sobre envelhecimento em seus cursos de graduação.

Seguem algumas falas que ilustram o que foi mencionado pelo grupo:

Na faculdade de educação física foi bem pouco aprofundado o envelhecimento. (P07) 
Na faculdade, a gente tem as matérias lógico, mas o conteúdo é muito fraco. Muito fraco. Você não consegue saber. Você dava uma pincelada. Mas no último ano já entrou, na época que eu fiz, processo de envelhecimento, o idoso, por isso eu fiz um trabalho sobre idosos já na graduação. Mas, foi muito básico, muito básico mesmo. (P10)

Bom, na minha graduação praticamente nada de envelhecimento, muito pouco. Teve assim no máximo pouca coisa de avaliação nutricional no idoso, mas muito pouco.

(P16)

E aí eu tive mais contato com o envelhecimento porque eu tive a oportunidade de fazer estágio aqui. Eu tinha uma professora que já trabalhava aqui e aí eu fui me interessando por essa área. Também me deu essa possibilidade de ampliar o conhecimento em relação ao idoso mais por interesse próprio, porque dentro da graduação, na grade curricular não tinha uma disciplina voltada para o envelhecimento.(P04)

Nem todos os participantes do grupo falaram sobre a aproximação com os conteúdos de gerontologia em sua formação. O debate pautou-se mais na questão das vivências em relação à interdisciplinaridade e interprofissionalidade, que serão apresentadas no item a seguir.

6.1.2 Acesso a interdisciplinaridade e interprofissionalidade na graduação

Os participantes do estudo foram questionados sobre o contato que tiveram com a interdisciplinaridade e a interprofissionalidade durante suas graduações e de que maneira este contato se deu. Foi possível observar que a maior parte deles (52\%) negou ter tido contato com experiências interdisciplinares ou interprofissionais neste período.

As falas em relação ao contato com a interdicisplinaridade durante a graduação puderam ser distribuídas na seguinte forma: 
Figura 1 - Contato dos participantes frente a interdisciplinaridade e a interprofissionalidade durante a graduação.

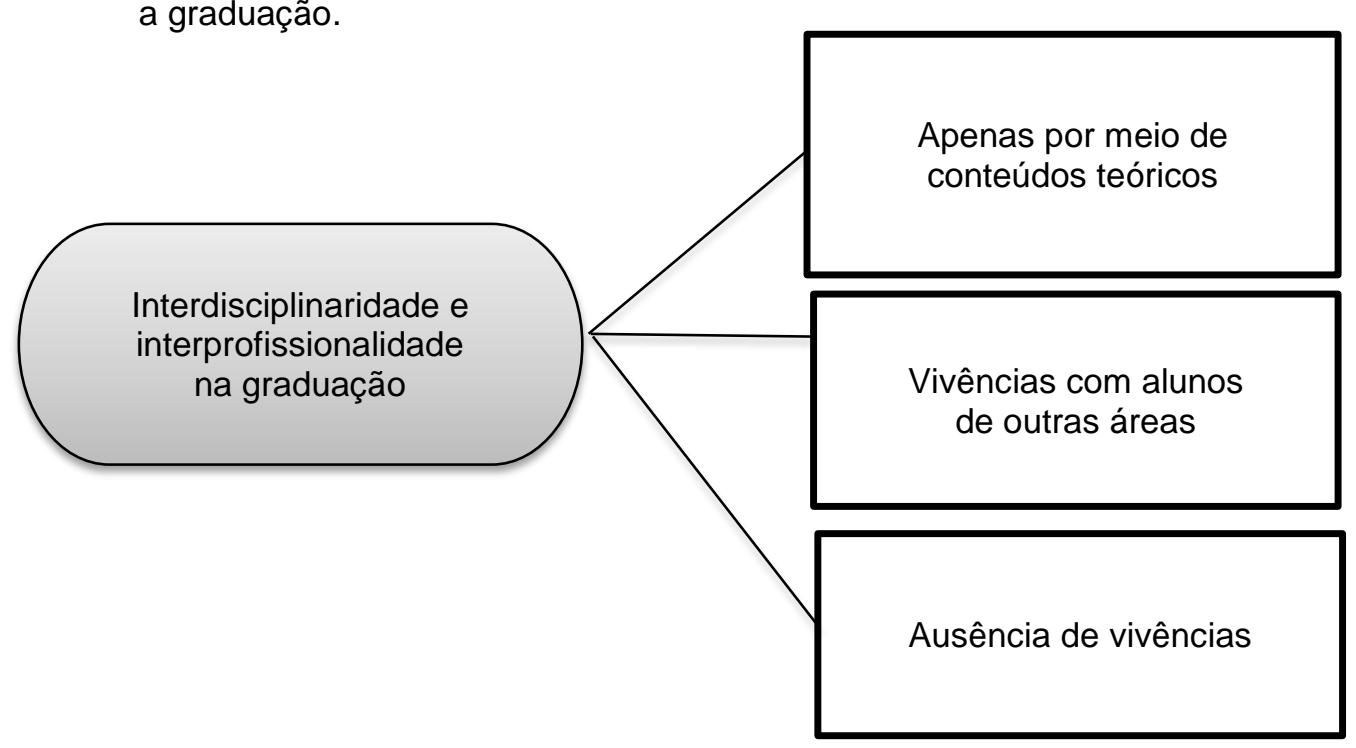

Fonte: Bruna Baviera, 2017.

Perante os relatos dos profissionais que negaram ter tido contato com a interdisciplinaridade e a interprofissionalidade, ficou explícito que durante as aulas havia grande enfoque na formação técnica da profissão e, por vezes, era mencionado o papel de outros profissionais da saúde. Também, lembraram que as disciplinas eram fragmentadas e o médico assumia o papel central na prestação de serviços em saúde.

É possível também observar que o tempo de formação pode ter influência nestes relatos, como visto no trecho abaixo:

Então, você sabe que eu já tenho uma certa idade de formação, na minha época não tinha nada disso. (P14)

Durante o grupo focal, alguns profissionais ressaltaram ter tido pouco contato com estas experiências, sempre trazendo falas como "não aprofundou" e "só uma 
abordagem assim mais inicial'. Alguns mencionam não ter tido nenhum contato com os conceitos, seguem algumas falas que ilustram estes fatos:

E aí essa esta questão mais entre as profissões, foi mais na prática mesmo, que a gente foi com o tempo construindo aqui também, porque não era assim, e acho que hoje a gente tem isso muito mais amadurecido e claro de que se eu estou com outro profissional então eu não vou estar lá querendo "meter o bedelho" no que não é meu. Mas é uma coisa que se completa e soma para o paciente. E antes a gente tinha essa confusão, "porque psico atender com TO, psico atender com Fisio, ai não pode isso não" então gerou aquela polêmica, e hoje a gente tem isso muito claro de que quando a gente junta as profissões só agrega, tanto para a gente quanto para o paciente. (...) acho que por conta da nossa formação, a gente não tem isso também claro na faculdade e até em pós que a gente faz, isso não é muito aprofundado. (P04)

Não tive nada de interdisciplinaridade nem de interprofissionalidade na graduação. Comecei a ter mais contato depois que eu saí da faculdade, eu comecei a fazer atendimento ambulatorial.(P14)

Por outro lado, os participantes que afirmaram ter tido contato com vivências interdisciplinares ou interprofissionais, trouxeram um discurso mais rico, relatando de que maneira estas experiências ocorreram.

Estas vivências aconteceram de maneira teórica, quando os participantes descreveram seminários, debates e dinâmicas em sala de aula, materiais de estudo de uma disciplina envolvendo textos e artigos que abordavam a interdisciplinaridade e a interprofissionalidade ou relataram a atuação de outros profissionais e o trabalho em equipe.

Este contato também aconteceu de maneira prática para alguns participantes, como discussões de caso clínico e atendimento conjunto com outros profissionais durante os estágios, participação em ligas de geriatria e gerontologia e módulos de 
disciplinas com grupos de alunos de várias áreas, onde planejavam e executam tratamentos em conjunto.

Então, a gente estuda junto com alunos da psico, a gente faz outras disciplinas junto com a fisio, no sentido assim, de que o saber, que aquele conhecimento não é importante só para minha área, mas para todos. (P13)

Durante a graduação, eu tive módulos que eram comuns a todas as disciplinas da área da saúde da minha faculdade. Então quando era trabalho especifico da saúde, eram escolhidos alguns pacientes da comunidade, eram formados grupo interdisciplinares, que atuam no domicílio ou instituições, então a gente montava o plano de tratamento juntos e atuava após as discussões. (...) foi no terceiro ano, mais ou menos. A vivência da faculdade que eu fiz, eles prezavam muito isso para o profissional, eles incentivavam essa troca. E na pós que eu fiz, também a prática tanto interdisciplinar quanto interprofissional era bastante forte.(P09).

A minha percepção é que a experiência na graduação e na pós é muito mais comungante, é muito mais importante, porque, eu vou falar por mim, minha experiência foi tão rica, que hoje, quando eu atendo um paciente domiciliar, eu me sinto só, eu não consigo. Eu tenho que pegar o telefone do fisioterapeuta e eu tenho que trocar. De saber o que a fono está fazendo. É uma coisa assim, porque eu aprendi a ser assim. Na graduação eu tive experiências que, mais do que estudar a interdisciplinaridade e a interprofissionalidade, foi possibilitar a vivência disso. Porque aí você visualiza. (...) Eu não vou dar conta disso sozinha. Você cai na real. Ninguém dá conta sozinho. (P13)

Deparamos que a aproximação ao tema deste estudo durante a graduação aconteceu mais de maneira teórica, e a prática com outros profissionais se concentrou nos estágios e atividades extras. Os profissionais que trouxeram relatos sobre o 
convívio com outros profissionais durante disciplinas e módulos comuns foram os profissionais com menor tempo de formação.

A seguir, mostraremos como o contato com a interdisciplinaridade e interprofissionalidade aconteceu para estes profissionais durante seus cursos de pósgraduação, onde notamos maior proximidade ao tema.

6.1.3 Acesso a interdisciplinaridade e interprofissionalidade na pós-graduação

A partir dos relatos nos questionários e no grupo focal, foi possível ver que os participantes tiveram mais contato com a interdisciplinaridade e a interprofissionalidade durante os cursos de pós-graduação, onde $80 \%$ (16 participantes) deles afirmam ter tido contato com estas vivências. As categorias estabelecidas seguem a seguinte distribuição:

Figura 2 - Contato dos participantes frente a interdisciplinaridade e a interprofissionalidade durante a pós-graduação.

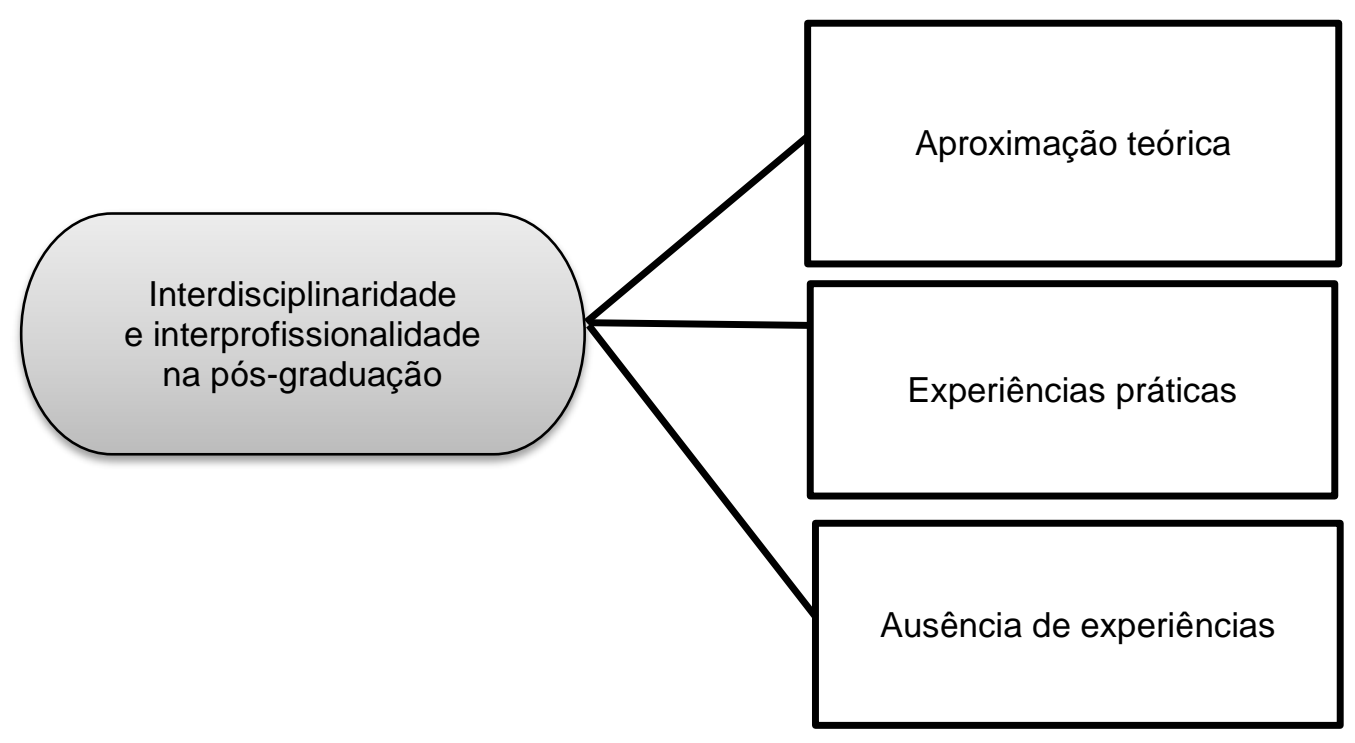

Fonte: Bruna Baviera, 2017. 
Verificamos que tais experiências ocorreram em sua maioria de maneira prática, principalmente por meio de discussões de caso clínico em equipes com diferentes profissionais, reuniões e no contato com eles em seu dia a dia de atendimentos. Destacamos as discussões de caso clínico, que foram citadas por metade dos participantes que possuíam pós-graduação. $\mathrm{O}$ hospital e o atendimento domiciliar aparecem aqui como principal local onde estas vivências aconteciam, mas há também relatos de como a abordagem destes conteúdos em aulas teóricas e com a participação de professores de diferentes áreas de formação contribuíram para a ampliação do conhecimento destes profissionais.

Eu acho que na faculdade é mais interdisciplinaridade do que interprofissionalidade, e aí na pós, eu fiz a pós em geronto também, e a experiência foi também para convergir. (P13)

E na de geronto, eu tive mais a parte de interprofissionalidade, não diretamente com o paciente, mas traziam alguns casos de geronto, como eram, tinham várias especialidades, inclusive médico, e eram muitos casos para serem discutidos e serem resolvidos entres equipes, então, dentro da sala de aula eram montados os grupos, com as equipes. (P11)

E na pós que eu fiz, também a prática tanto interdisciplinar quanto interprofissional era bastante forte. (P09)

O convívio com profissionais de outras áreas se intensificou nos cursos de pósgraduação, ampliando conhecimento sobre as diferentes áreas de atuação. Entretanto, apareceram discursos de que os temas interdisciplinaridade ou interprofissionalidade não tiveram destaque nos conteúdos ministrados em sala de 
aula, destaque que é representado pelos participantes como não tendo aulas específicas para apresentar os temas.

Foi possível notar que, muitas vezes, a interdisciplinaridade e a interprofissionalidade se "misturavam" nas falas dos participantes, havendo por vezes uma dificuldade em separar os conceitos. A seguir, apresentaremos as definições que estes profissionais nos trouxeram a respeito dos dois elementos.

\subsection{Definição dos conceitos}

Os participantes do estudo foram convidados a definir a interdisciplinaridade e a interprofissionalidade usando suas percepções, por meio do questionário distribuído. Abaixo apresentaremos estas definições, começando pela interdisciplinaridade.

Quando questionados sobre o que é a interdisciplinaridade, as respostas aparecem dentro das seguintes categorias:

Figura 3 - Definição de interdisciplinaridade na perspectiva dos participantes.

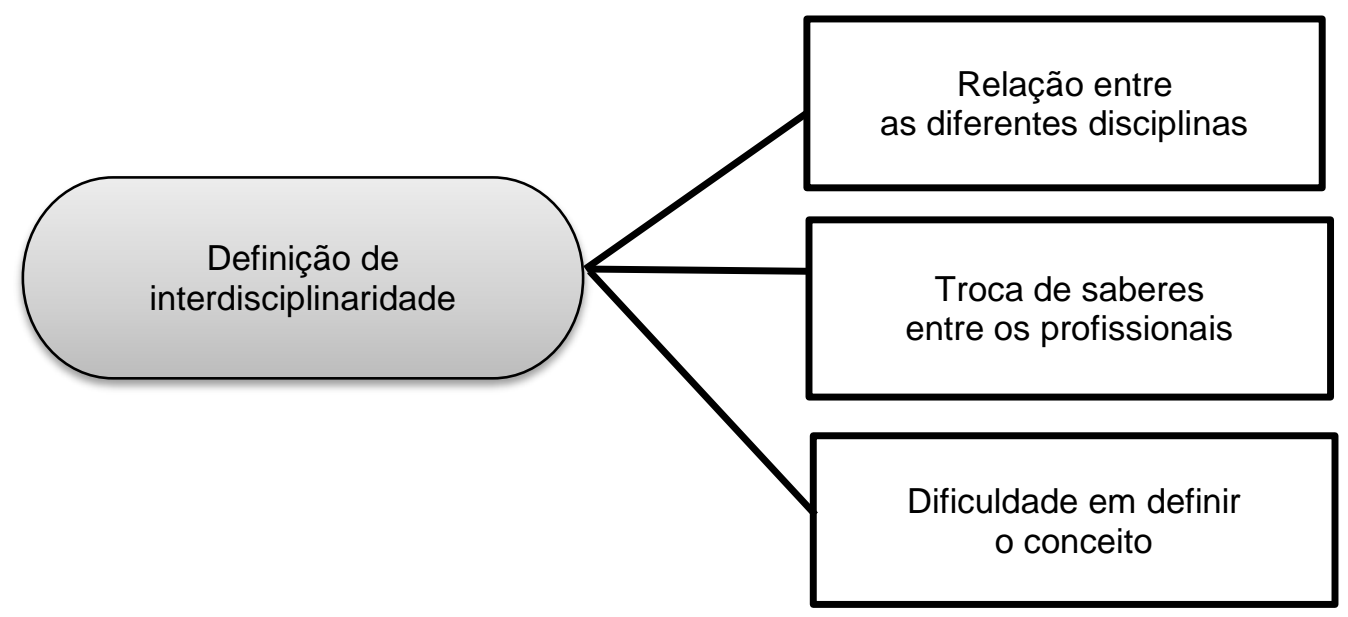

Fonte: Bruna Baviera, 2017. 
A seguir segue uma descrição de cada categoria discriminada na figura acima.

Relacão entre as diferentes disciplinas: composta pelos relatos de 12 participantes, que trazem nesta categoria as relações, as interconexões e a convergência entre os diferentes campos de saber, relacionando o termo ao campo teórico, valorizando a "horizontalização" entre os saberes e o surgimento de "novos saberes" a partir destas relações. Seguem algumas falas que ilustram a categoria:

(...) O conteúdo que surge é novo e não significa a simples soma das duas partes, mas sim o desenvolvimento de um terceiro saber. (P13)

A interdisciplinaridade é a interligação, integração e/ou convergência entre duas ou mais disciplinas. (P18)

Interdisciplinaridade é a proposta de integração entre conteúdos e conhecimento de uma disciplina com outras áreas, havendo um diálogo entre elas, além da tentativa de horizontalização entre os diferentes saberes. (P20)

Trocas de saberes entre os profissionais: relatada por dois participantes, esta troca se daria no diálogo com diferentes profissionais, ampliando o campo de saber de cada profissão, para entendimento do objeto de estudo de maneira integral. Seguem algumas falas:

Oportunidade de troca de conhecimentos específicos de cada profissional sobre o mesmo tema. (P5)

É a troca de saberes em atendimentos, considerando o sujeito como ser integral, que possui necessidades que ultrapassam os limites impostos em relação às especificidades de cada profissão. (P9) 
Dificuldade em definir o conceito: nesta categoria, aparecem os relatos de sete participantes que "misturaram" o conceito de interdisciplinaridade com o conceito de interprofissionalidade, trazendo relatos da prática em conjunto com outros profissionais. Algumas falas que ilustram:

É o trabalho em conjunto no atendimento de pacientes. (P15)

É a atuação conjunta da equipe multiprofissional. (P16)

(...) cada um contribuindo de acordo com a sua experiência para o planejamento, tratamento e alta do paciente, não necessariamente todos os profissionais terão que atendê-lo, mas podem contribuir de alguma forma. (P04)

Apresentaremos agora as respostas dos participantes em relação ao conceito de interprofissionalidade, que puderam ser dividas nas seguintes categorias:

Figura 4 - Definição de interprofissionalidade na perspectiva dos participantes.

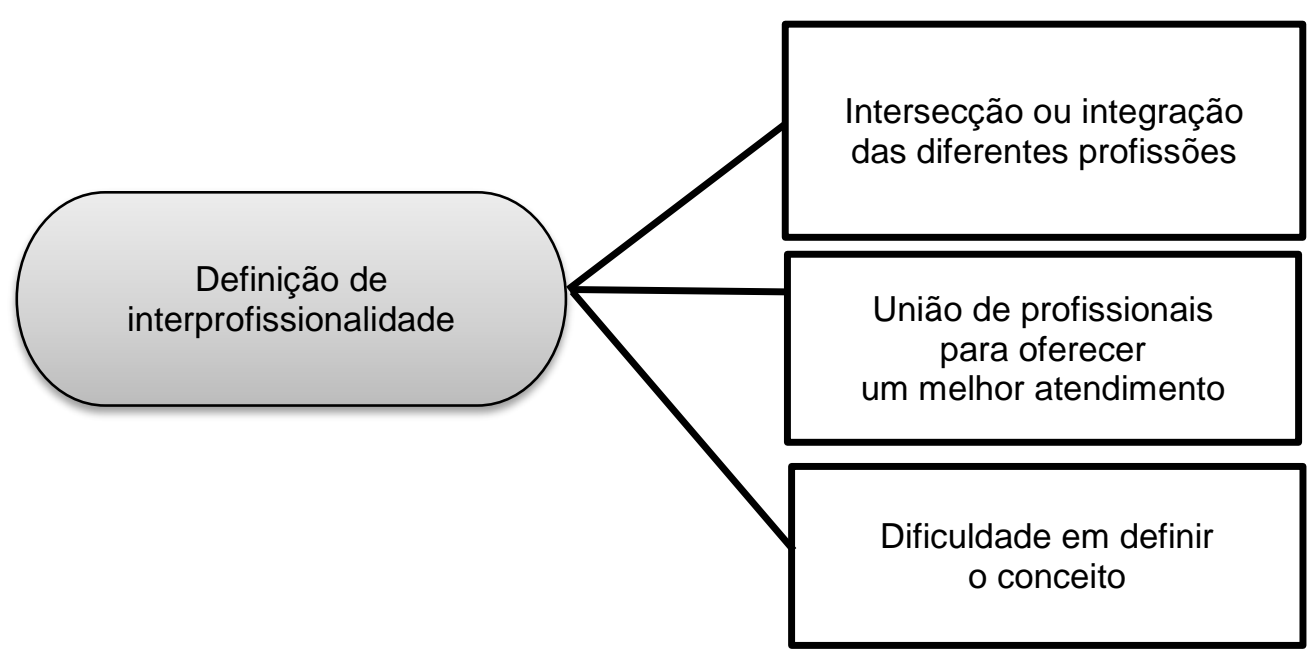

Fonte: Bruna Baviera, 2017. 
Abaixo segue uma descrição das categorias.

Interseccão ou integracão entre as diferentes profissões: composta por 12 profissionais, eles apresentaram nesta categoria as relações entre as diferentes profissões da saúde para o atendimento em conjunto de pacientes, bem como o planejamento de abordagens de cuidado, compartilhando objetivos e metas. Abaixo algumas falas para ilustração:

É a possibilidade de intersecção entre as profissões. Momento de compartilhar ideias e traçar objetivos com a função de planejamento e execução de metas, seja em função do tratamento de um paciente ou um plano de ação que envolva dois ou mais profissionais. (P4)

É a integração/correlação do conhecimento de cada profissional, utilizando-se dessa "informação global" (transitando entre as profissões) com um objetivo comum. (P6)

Acredito que é quando duas áreas de atuação se unem para atender as necessidades de um paciente/cliente. (P12)

É a relação entre as diferentes profissões, que interagem entre si, para juntas serem as mais resolutivas possíveis em torno de um objetivo/tarefa em comum. (P21)

União de profissionais para oferecer um melhor atendimento: nesta categoria, aparecem as respostas de três participantes, que associaram a união de diferentes profissões à necessidade de oferecer atendimentos de melhor qualidade aos pacientes. Seguem falas destacadas sobre este aspecto:

É a discussão sobre as possibilidades de intervenção com os diversos profissionais, independente da especificidade do profissional, para assim oferecer o melhor para o paciente. (P9) 
(...) profissionais de outras formações que trabalham juntos, tomam decisões, planejam e agem juntos, facilitando assim um melhor resultado. $(P 11)$

São várias profissões atuando juntas para o melhor cuidado com a pessoa. (P19)

Dificuldade em definir o conceito: nesta categoria apareceram seis profissionais que afirmaram desconhecer o conceito ou o relacionam com outras formas de atuação profissional, sem interação e sem objetivos em comum, ou apenas definem como trabalho em equipe. Abaixo falas que ilustram esta dificuldade:

Quando uma equipe multidisciplinar se junta para atender determinado caso. Não necessariamente tem o mesmo objetivo. (P3)

Conhecimentos específicos de cada profissional. (P5)

Trabalho de diversos profissionais que não necessariamente estão interligados diretamente. (P14)

Interessante destacar aqui, que as falas apresentadas na última categoria, onde havia uma dificuldade em descrever o conceito de interprofissionalidade, pertencem aos participantes com maior tempo médio de anos de experiência na gerontologia, se comparados aos demais, que definiram o conceito de outra forma. A mesma situação também pode ser vista na definição do termo interdisciplinaridade.

Para melhor ilustrar este fato, os participantes que definiram o termo interdisciplinaridade como "relação entre as diferentes disciplinas" tinham em média 5,3 anos de experiência na gerontologia. Os que definiram o termo como "trocas de saberes entre os profissionais", tinham em média 6,8 anos de experiência nesta 
atuação. Já os que tiveram dificuldades em definir o termo, tinham em média 7,9 anos de experiência na atuação com idosos.

$\mathrm{Na}$ definição do conceito de interprofissionalidade esta diferença se tornou maior. Os participantes que definiram como "intersecção ou integração entre as diferentes profissões" tinham um tempo médio de experiência na gerontologia de 6,7 anos. Os que definiram como "profissionais que se juntam para oferecer um melhor atendimento", tinham em média 2,6 anos de experiência com idosos. Já os que tiveram dificuldade em definir o conceito, tinham o tempo médio de experiência na gerontologia de 10,4 anos.

Apesar das diferentes definições, os participantes conseguiram discorrer sobre a importância da interdisciplinaridade e da interprofissionalidade para suas práticas profissionais, que serão destacadas no próximo item.

\subsection{A importância da interdisciplinaridade e da interprofissionalidade para a atuação profissional}

Após a apresentação das características destes profissionais, suas vivências durante a formação acadêmica e profissional e suas percepções a respeito dos conceitos de interdisciplinaridade e interprofissionalidade, entraremos em um novo momento do estudo, no qual os participantes apresentam suas considerações a respeito da importância dos dois conceitos em sua prática profissional. Pretendemos aqui mostrar como esta realidade é vivenciada em seu cotidiano de trabalho com idosos, a relevância para esta atuação, fatores que dificultam ou facilitam estas abordagens. 
6.3.1 A importância da interdisciplinaridade para a atuação profissional

Os profissionais descreveram a relevância da interdisciplinaridade na sua atuação profissional com idosos dentro de três categorias, mostradas na Figura 5:

Figura 5 - Importância da interdisciplinaridade na atuação profissional, de acordo com os participantes.

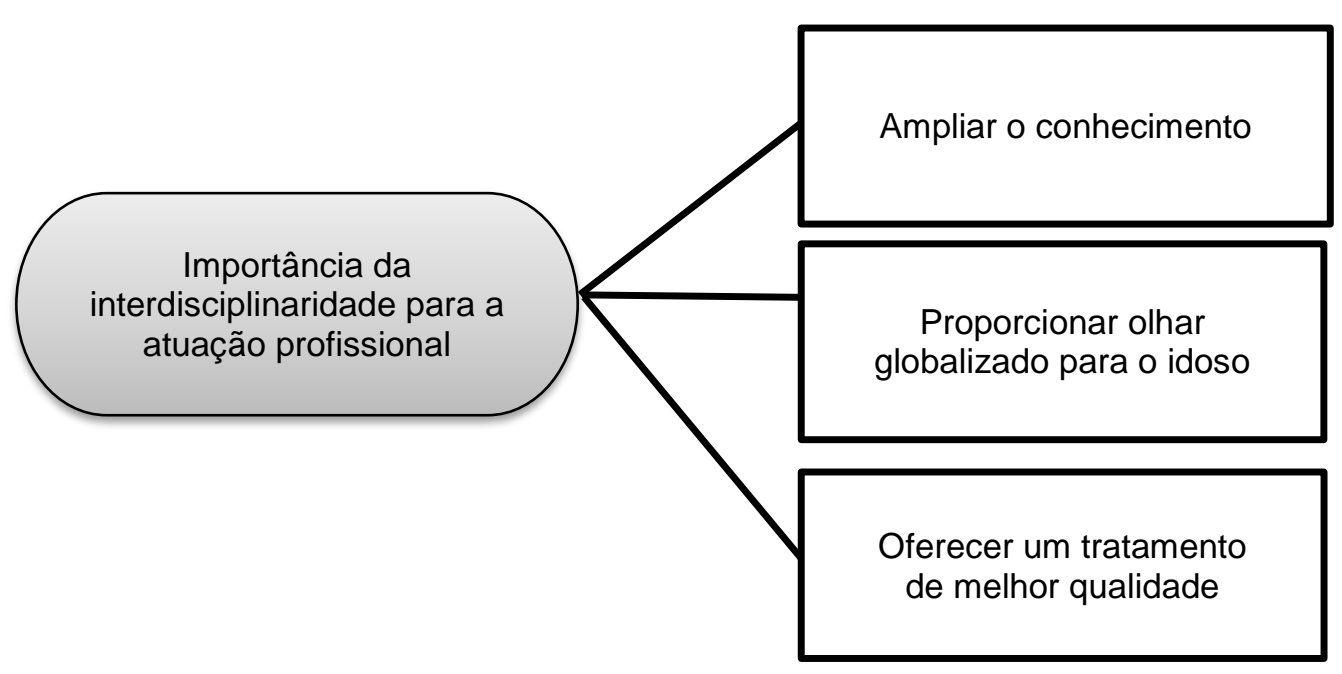

Fonte: Bruna Baviera, 2017.

As categorias apresentas acima, podem ser descritas da seguinte forma:

Ampliar o conhecimento do profissional: nesta categoria, os participantes enfatizaram a relevância da interdisciplinaridade para ampliação de seus conhecimentos, o que contribui diretamente para um melhor planejamento e execução de suas condutas profissionais. Três dos participantes apresentaram respostas neste sentido.

Pode determinar e, muitas vezes, determina minha conduta como assistente social, pois possuo saberes agregados para além de minhas competências profissionais. (P8) 
É importante para melhor conhecimento de determinado assunto. (P11)

A importância se dá na construção do raciocínio clínico, na sensação de liberdade para buscar outros referenciais teóricos para embasar a prática, que não só a da nossa profissão. (P13)

Proporcionar um olhar globalizado para o idoso: as respostas neste sentido demonstraram a complexidade do humano, mas especificamente do idoso, e a necessidade deste olhar globalizado na atuação dos profissionais. Nove participantes referiram respostas nesta linha de pensamento.

Acredito que qualquer paciente que atenda precisa ser visto como um todo. (P3)

A interdisciplinaridade é importante, pois proporciona um conhecimento global, ou seja, analisar o indivíduo ou situação como um todo. (P7)

Para trabalhar com o idoso não posso saber só de psicologia e sim um pouco de todas as áreas devido à complexidade desta faixa etária/fase da vida. (P15)

Oferecer um tratamento de melhor qualidade: 12 participantes do estudo trouxeram em suas respostas a importância da interdisciplinaridade para a oferta de um cuidado de melhor qualidade aos idosos, com abordagens amplas e visando uma melhor qualidade de vida do sujeito atendido.

(...) Através da interdisciplinaridade pode-se estabelecer o melhor plano de cuidado para o paciente. (P2)

(...) Precisamos alinhar os conhecimentos para elaborar um plano terapêutico que a pessoa seja o mais beneficiada possível. (P3) 
Para planejar um melhor atendimento ao paciente, visando assim uma melhor qualidade de vida para o mesmo. (P11)

Uma vez apresentadas as falas sobre a importância da interdisciplinaridade, seguiremos com as falas dos participantes a respeito da importância da interprofissionalidade.

\subsubsection{A importância da interprofissionalidade para a atuação profissional}

Da mesma maneira, os participantes também foram questionados sobre a relevância da interprofissionalidade para sua atuação profissional com idosos. As respostas dadas também se enquadraram em três diferentes categorias, não muito diferentes das categorias apresentadas no item anterior.

Figura 6 - Importância da interprofissionalidade na atuação profissional, de acordo com os participantes.

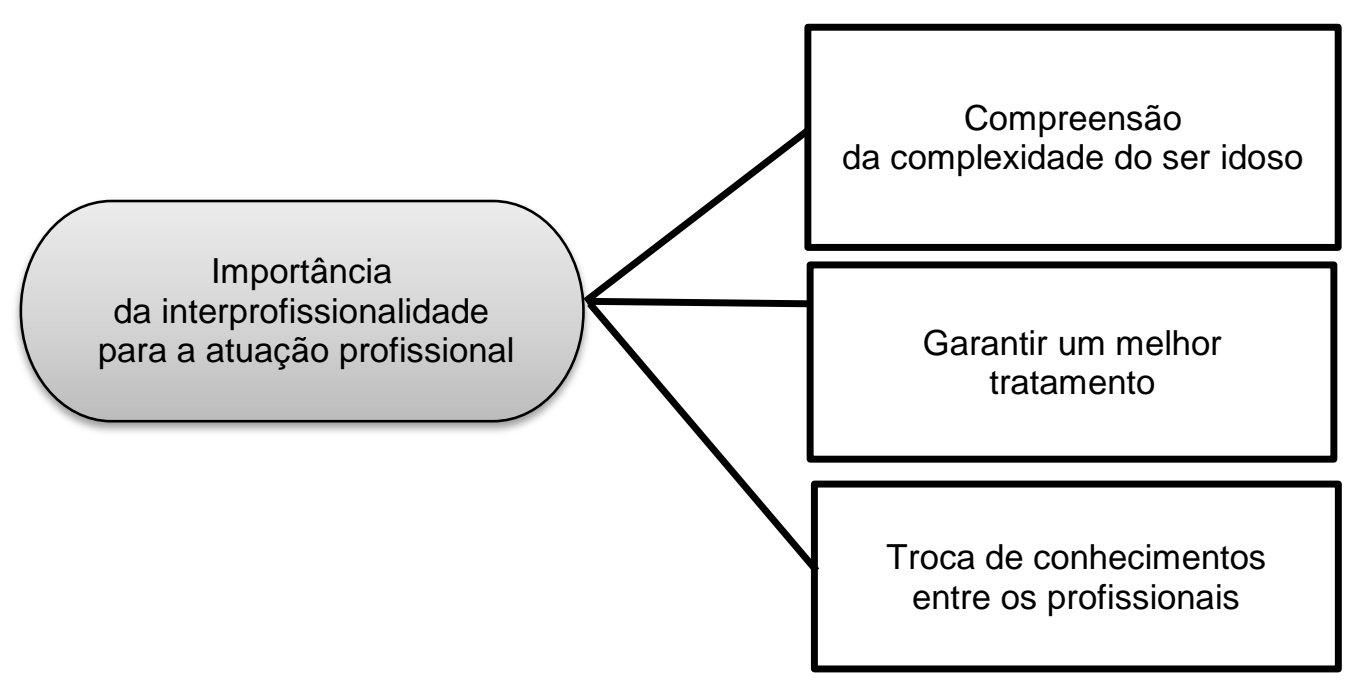

Fonte: Bruna Baviera, 2017.

As categorias mencionadas na figura seguem descritas abaixo: 
Compreensão da complexidade do ser idoso: nesta categoria, quatro profissionais apresentaram sua percepção de que sozinhos não conseguiriam compreender e atender todas as necessidades de um paciente idoso, destacando a relevância das discussões com outros profissionais para alcançar tal compreensão.

É importante discutir os casos, pois nem sempre os pacientes só têm um problema. (P11)

(...) somente como fisioterapeuta não consigo avaliar/tratar o idoso na sua totalidade e complexidade. (P12)

Melhor compreensão do objeto de trabalho. (P17)

Garantir um melhor tratamento: a maioria dos participantes do estudo (18 profissionais) apresentou em suas respostas relatos que destacam a importância do trabalho interprofissional para a garantia de um melhor cuidado ao idoso atendido, um cuidado ampliado, que alcance todas as necessidades deste paciente.

A troca entre as profissões e profissionais sempre contribui para $o$ melhor caminho em relação ao tratamento e possibilidades de alcances de cada profissão. Quando diferentes profissionais podem expor suas ideias e objetivos o plano de tratamento ou ação a ser realizada será mais rica e melhor elaborada. (P4)

Quando o trabalho é feito em equipe, os resultados são melhores, pois as decisões normalmente são assertivas. $O$ trabalho em equipe ajuda muito na evolução do paciente, onde todos os profissionais envolvidos podem contribuir para melhores resultados. (P11)

(...) as quais podem se expressar através de ações interprofissionais, sendo estas diferenciais marcantes em minha experiência profissional para a obtenção de resultados mais interessantes e significativos para 
o paciente, pois amplia a potência de construir o atendimento no momento em que ele ocorre. (P13)

Troca de conhecimentos entre os profissionais: esta troca de conhecimentos acontece no contato com profissionais de diferentes áreas e aparece como relevante na fala de nove participantes do estudo. A troca de conhecimentos e informações amplia o olhar do profissional para o idoso e suas necessidades.

Importante, pois, pode-se adquirir conhecimento na troca de ideias com outros profissionais e também transmitir algum conhecimento para outros. (P2)

É importante aprender com outros profissionais da saúde coisas novas, rever conceitos, tirar dúvidas e atuar junto. (P3)

É importante discutir sobre diferentes possibilidades e conhecer diferentes pontos de vista (dos diferentes profissionais) para direcionar da melhor forma a própria intervenção do paciente. (P9)

Após a apresentação da percepção da importância dos conceitos em sua atuação profissional, os participantes do estudo elucidaram suas opiniões sobre os fatores facilitadores e dificultadores para o acontecimento da interdisciplinaridade e interprofissionalidade.

\subsubsection{O dia a dia de trabalho: fatores facilitadores e fatores dificultadores}

Neste novo momento, apresentamos o relato dos participantes durante o grupo focal, sobre como as vivências interdisciplinares e interprofissionais podem se dar no cotidiano de trabalho de saúde com o público idoso. Apresentaremos estas percepções divididas em dois sentidos: dos fatores que favorecem a interdisciplinaridade e a interprofissionalidade e dos fatores que se apresentam como 
barreiras ao seu acontecimento real. Apresentaremos também algumas falas que ilustram estes fatores.

Começaremos então pelos fatores facilitadores, que se apresentam nas respostas de duas maneiras: a partir da perspectiva dos fatores intrínsecos do profissional, e dos fatores que envolvem a relação com outros profissionais.

Figura 7 - Fatores facilitadores para a interdisciplinaridade e a interprofissionalidade na perspectiva dos participantes.

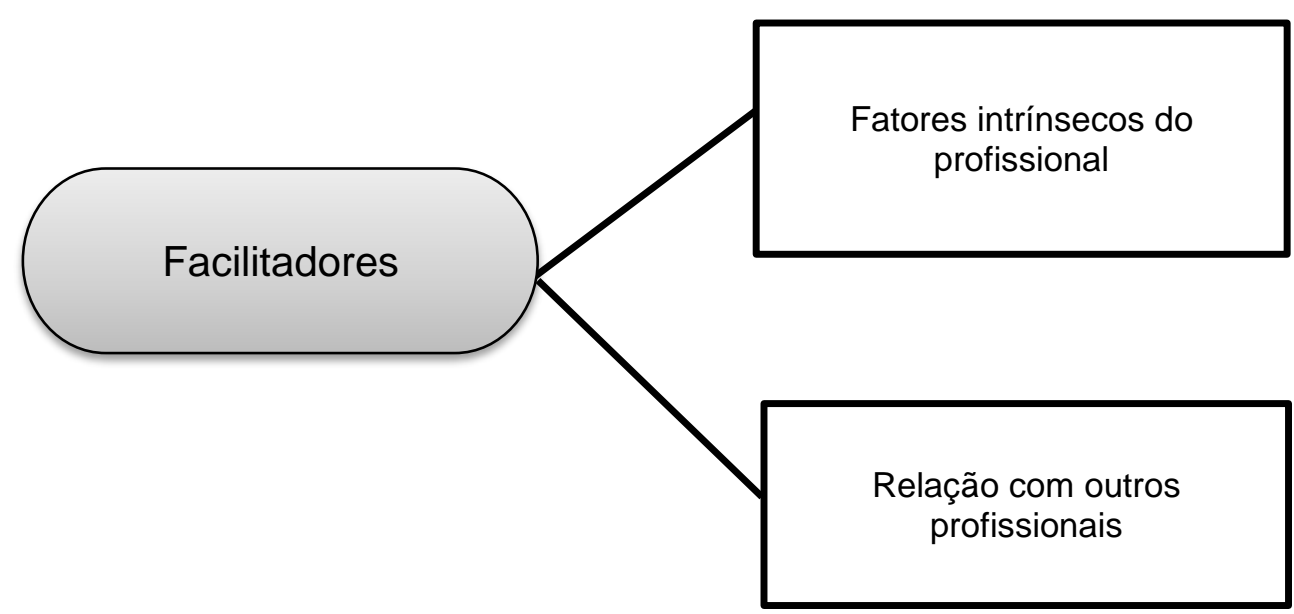

Fonte: Bruna Baviera, 2017.

Fatores intrínsecos do profissional: foram citados pelos participantes alguns fatores do próprio profissional que colaboram para o acontecimento da interdisciplinaridade e da interprofissionalidade, como a motivação no trabalho, o desejo de oferecer o melhor para o paciente, a confiança e experiência prática, flexibilidade e clareza do seu papel na equipe. Relataram também a importância de o profissional "desmistificar" algumas crenças e medos, no sentido de se permitir viver as experiências de trocas.

Bom o que eu acho que ajuda seria, além do nosso conhecimento, é da nossa motivação de trabalhar, de querer o melhor para o paciente. (P16) 
Eu acho que o que favorece é a gente ter muita clareza do nosso papel. Se cada um de nós sabe o que é o nosso papel na situação com o paciente, nós saberemos onde estará o seu limite. (P05)

Fatores que envolvem a relação com outros profissionais: no sentido da relação, o primeiro fator que aparece como facilitador é o objetivo em comum dos profissionais, pois todos pretendem obter bons resultados no tratamento de saúde do idoso. Segundo os participantes, isto os aproxima. No mesmo caminho da aproximação, aparecem as reuniões e discussões de caso entre os diferentes profissionais, momentos que possibilitam as trocas e a abertura para ouvir outras opiniões. Tal aproximação facilita o convívio, a criação de vínculos e amizade, que segundo as respostas obtidas, permitem uma melhor liberdade para transitar entre os diferentes campos de conhecimentos e de atuação. Por fim, os participantes também citam a importância de transmitir seus conhecimentos uns aos outros, fazendo com que haja segurança e confiança em relação ao trabalho destes profissionais. Todos estes fatores favoreceriam a integração na equipe, de acordo com os participantes.

Então, na verdade, eu acho que a palavra essencial seria conhecimento. Propagar conhecimento daquilo que a gente faz. A gente ter essa segurança da prática e a gente demonstrar, falar com o outro, passar adiante. $O$ conhecimento e a informação a gente tem que passar adiante. Não é por passar o conhecimento que eu tenho para Fulano ou Beltrano, que essa pessoa, que eu vou deixar de existir, que ela vai tomar meu lugar ou qualquer coisa do tipo. Eu acho que conhecimento, mostrar as informações e os benefícios que a gente tem da forma que a gente atua. Eu acho que esse pode ser um dos caminhos. (P4)

(...) o quanto este vínculo é válido em tudo isso que está sendo colocado, de cada um saber seu papel e tudo mais. Esse vínculo de 
tanto tempo de convívio e de contato, de uma amizade, vamos dizer, deixa um espaço tão confortável, que você consegue transitar, você consegue não se sentir invadindo. (P13)

Eu acho que o facilita bastante assim é quando a gente faz discussão de caso, tem reunião com vários profissionais de um mesmo paciente. (P15)

É uma segurança né, que você tem no profissional, de você conhecer o trabalho dele, de você entender qual a importância do outro profissional também no seu trabalho. Porque, as vezes, é uma cadeia. Eu dependo do trabalho do outro para que o meu também seja efetivo. (P09)

Após esta apresentação sobre os fatores considerados pelos participantes como facilitadores, mostraremos a seguir os fatores que impactam de maneira negativa para a ocorrência da interdisciplinaridade e da interprofissionalidade. Estes aspectos foram divididos em três categorias, que são as seguintes:

Figura 8 - Fatores dificultadores para a interdisciplinaridade e a interprofissionalidade na perspectiva dos participantes.

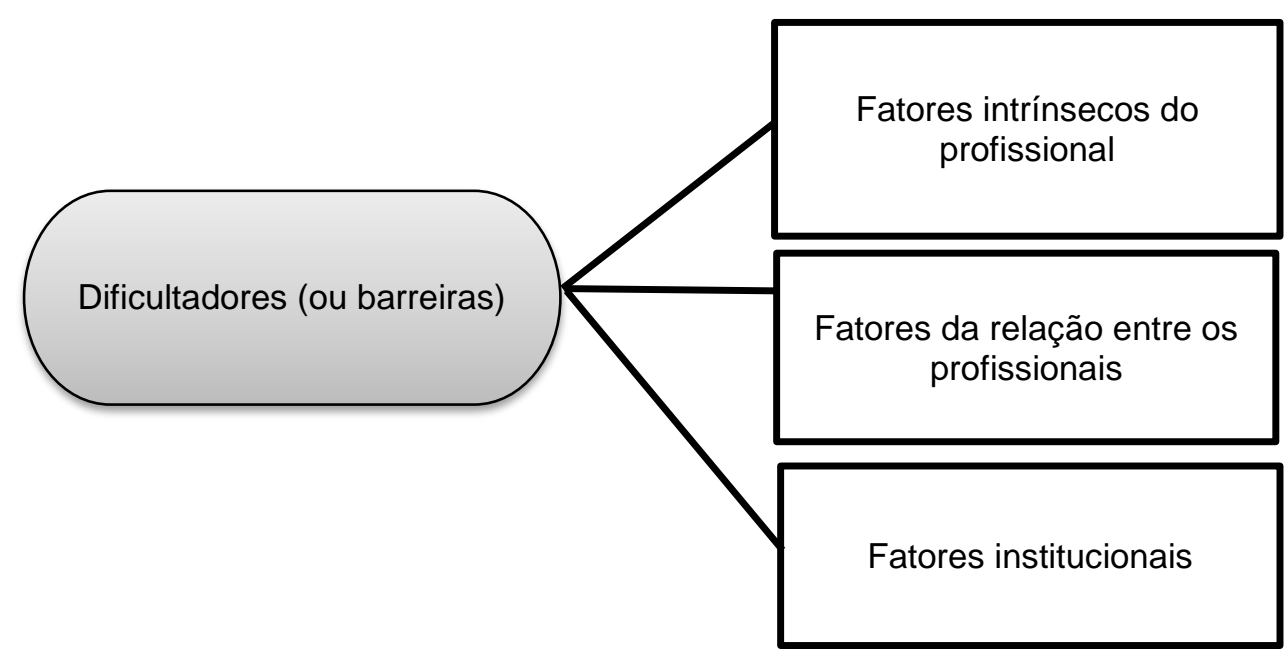

Fonte: Bruna Baviera, 2017. 
A descrição destas categorias segue abaixo:

Fatores intrínsecos do profissional: de acordo com os participantes, alguns profissionais não apresentam um "perfil" que favorece as relações com os demais membros da equipe, não permitindo uma abertura para as trocas e aproximação. Novamente surge como importante a clareza do papel dos profissionais. Falta de conhecimento e vaidade também aparecem nas falas dos entrevistados.

E acho que tem também o perfil do profissional. Nem todo profissional se coloca nessa relação. Eu sei que tem pessoas que falam "prefiro atender sozinho" e aí a gente também tem que lidar com isso. Não dá para obrigar o outro a fazer uma coisa que não vai ser produtiva para ele. (P04)

(...) se eu não tenho clareza do que é o meu eu vou fazer o do outro. E aí essa coisa de vaidade, de você tomar o meu espaço. Quando cada um sabe o seu papel isso não acontece. Mas eu acho que, além dos problemas burocráticos, esse é o problema maior. Porque a burocracia a gente dribla, a gente contorna, a gente dá um jeito. Mas agora se a equipe ou o outro profissional que está comigo não tiver essa clareza, eu não faço esse trabalho e aí é mais difícil. (P05)

Fatores da relação entre os profissionais: os participantes apontaram aqui as relações disputadas entre os profissionais, na tentativa de defender seus campos de atuação. Também, referiram as dificuldades e o medo de lidar com profissionais de hierarquias superiores, que, muitas vezes, podem não ter a compreensão da importância da interdisciplinaridade e da interprofissionalidade para a atuação destes participantes. Muitas vezes, as pessoas nas posições superiores podem não dar a oportunidade destes profissionais desenvolverem tal prática. 
Porque se a gente está em uma relação disputada, quer dizer, "então eu vou fazer o trabalho da psico e a psico vai se sentir ameaçada". Acontece muito isso nos bastidores, quando os serviços se propõem a fazer o trabalho inter, hospital por exemplo, e você quer fazer uma proposta, mas isso não é seu. De uma forma as vezes não dita, você não pode fazer, porque tem uma coisa assim que é defender seu espaço nessa briga categórica, que não necessariamente é uma boa prática, mas influencia na relação de trabalho. (P13)

Eu acho que a hierarquia também as vezes atrapalha, igual a J. falou, desta coisa assim "ah é o médico", ou a pessoa ali tem um cargo, e ele tem medo um pouco de se abrir para conhecer o que o outro profissional acha do mesmo paciente que ele atende. (P15)

Às vezes é "é assim assado, vai ficar assim assado". As vezes acaba também dificultando a vontade do profissional, a motivação que ele tem de tentar colocar algo novo na prática. (P16)

Fatores institucionais: neste aspecto surgem as questões burocráticas, administrativas e de metas impostas pelas instituições. Como apresentado nas falas, ter mais de um profissional atendendo conjuntamente pode se tornar inviável por conta de aspectos de produção, como as metas e agendas do serviço.

E eu acho que o que complica muito este trabalho, seriam as partes mais burocráticas e administrativas, às vezes, do lugar onde a gente trabalha né. A gente poderia atuar muito mais se talvez não tivessem, não digo regras, mas metas, a gente tem que ter um controle muito grande para não perder mão ou qualquer coisa do tipo. (P16)

É, mas dentro deste percurso, várias coisas vão emperrando aí. Acho que esta questão administrativa é uma das básicas assim, então "ah eu não posso bloquear a agenda para dois profissionais atenderem o mesmo paciente". E a gente tem essa questão mais interprofissional quando é grupo, por aí a gente consegue mobilizar mais atendimentos 
para um ou mais profissionais estarem ali. Agora quando o paciente é um só e a gente precisa ter essa relação com o outro profissional aí a gente não consegue caminhar porque não dá para atender três pessoas com um paciente. Então esta é a questão burocrática. (P16)

Após apresentar as barreiras e facilitadores para a implementação da interdisciplinaridade e da interprofissionalidade na prática cotidiana em saúde, os participantes contribuíram com as possibilidades de aprendizado destas capacidades em seu dia a dia de trabalho.

6.4 Aprendendo habilidades de interdisciplinaridade e interprofissionalidade

Os profissionais entrevistados também contribuíram com suas percepções sobre como adquiriram habilidades interdisciplinares e interprofissionais. Alguns dos participantes afirmaram que não tiveram contato com os conceitos ao longo sua formação, tendo que aprender tais habilidades a partir do momento que começaram a atuar no atendimento dos idosos. Durante o grupo focal, eles compartilharam suas experiências de aprendizado com a prática, as quais foram distribuídas em três categorias: 
Figura 9 - fatores que contribuíram para o aprendizado da interdisciplinaridade e interprofissionalidade com a prática profissional.

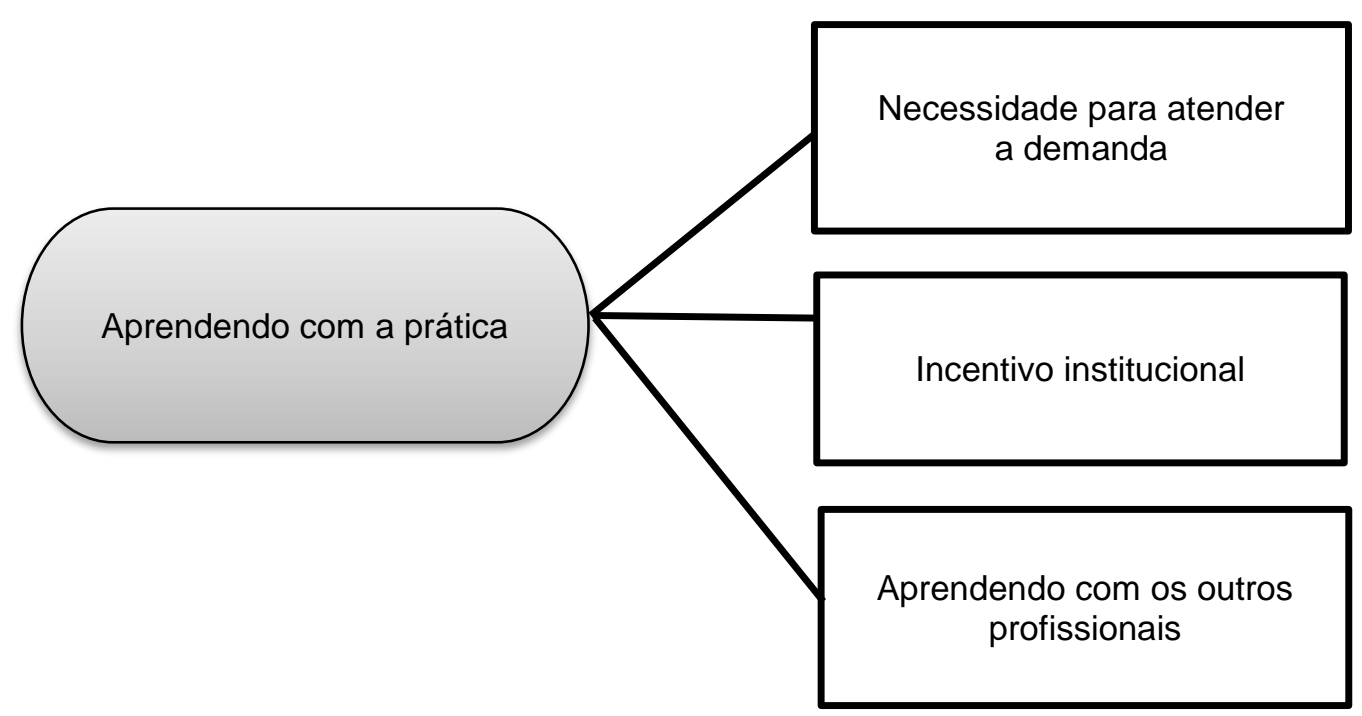

Fonte: Bruna Baviera, 2017.

Uma descrição mais detalhada destes fatores segue abaixo:

\section{Aprendizado necessário para atender a demanda dos idosos: os} participantes apresentaram como o trabalho com idosos na prática contribui para o aprendizado da interdisciplinaridade e da interprofissionalidade.

Foi a prática né, porque a gente percebeu que tinha benefício para o paciente também no tratamento. A gente conseguiu ter uma comparação de como era antes e como estava agora com a participação de outros profissionais. E daí a gente percebeu que melhorou tanto para a gente quanto para o paciente. (P04)

Eu acho que a prática mostra para você o que, a necessidade de buscar isso, porque você não dá conta. Dentro da Geronto, a gente tem que ter muita consciência de que a gente trabalha com pessoas, e não com doenças. Porque tratar a doença é fácil. (...) Na prática, começou a sentir uma necessidade de um complemento do que aprendeu a fazer. E aí faz diferença.(P05) 
Incentivo por meio de ações institucionais: nesta categoria, os profissionais discorreram sobre como as ações institucionais reverberaram no aprendizado dos profissionais em relação à interdisciplinaridade e a interprofissionalidade.

E aí, nesse tempo, eu comecei a trabalhar em instituição de longa permanência, onde a gente também era mais multi do que inter, e com o passar do tempo, com as mudanças nas direções e nas lideranças, a gente começou a ser mais interdisciplinar.(...) A gente começou a ter reuniões frequentes, de discussões de caso e tal, onde a gente começava a entender um pouquinho da área do outro. (P16)

E tem muita coisa também a que a gente aprendeu aqui na instituição, por conta de todas as discussões, as triagens, todas as avaliações, a gente discutiu tanto tempo as triagens e os instrumentos, fez com que, com certeza, a gente ganhasse muita prática e começasse a afinar um pouco mais nossos conhecimentos, então eu acho que é isso. (P16)

Aprendendo com os outros profissionais: neste aspecto, os profissionais discorreram como o contato com os outros colegas foi benéfico para este aprendizado.

(...) começando a colocar já em prática coisas que a gente já aprendeu em um momento com o outro profissional.(...) Com as conversas, com os conhecimentos, a gente sabe que a consistência "xis" é mais segura até uma avaliação, então esse é um dos exemplos né, que a gente começou já a colocar em prática. (P16)

O vínculo que a gente vai construindo, entre Psico e TO, por exemplo, é uma coisa assim, a gente vai se permitindo, um experimentar o outro, trocando, "o que você achou?", "como é que você usou? (P13)

Acho que na prática clínica, quem trabalha com a assistência, acho que fica mais fácil não só aprender ali na prática como aplica este 
conteúdo teórico, por mais que seja básico, você vai se especializando e os outros colegas também ali. É para aumentar este conteúdo. (P14)

As falas dos participantes nos trazem as suas várias experiências no cotidiano de trabalho com idosos. No próximo capítulo, iremos contrapor tais informações levantadas de acordo com os aspectos encontrados na literatura. 


\section{Discussão}

Pretendemos neste capítulo estabelecer um diálogo entre os resultados apresentados e os referenciais teóricos encontrados para subsidiar esta discussão. A maioria dos entrevistados relatou que a interdisciplinaridade no trabalho em saúde reflete diretamente na qualidade do atendimento prestado ao usuário, que passa a receber uma assistência holística, e integral. Os mesmos resultados também puderam ser observados no estudo de Souza e Souza (2009). Iniciaremos esta discussão a partir das diferenças na formação dos participantes de nosso estudo.

\subsection{Sobre o perfil de formação dos participantes e suas percepções a respeito dos conceitos}

Como foi possível verificar na apresentação dos resultados, os participantes possuíam tempo de formação e de experiência na gerontologia bem diversificados. Da mesma maneira, seu contato com a interdisciplinaridade e a interprofissionalidade na formação acadêmica e profissional também se deu de diferentes formas.

De acordo com Gattás (2006) a discussão sobre interdisciplinaridade e interprofissionalidade na formação acadêmica não é contemplada na Lei de Diretrizes e Bases da Educação Nacional, promulgada em 1996. Ainda segundo a autora, as universidades têm autonomia para criar e organizar seus cursos de graduação, bem como estabelecer seus conteúdos, programas e projetos.

Desta maneira, a perspectiva interdisciplinar só é contemplada nas universidades, seja nos cursos de graduação ou de pós-graduação, se estas instituições reconhecerem seu valor e assim o desejarem. (Gattás, 2006). Isto certamente implica em formações heterogêneas para os profissionais da saúde, devido às experiências individuais que cada um teve em sua formação. No estudo de 
Souza e Souza (2009), a maioria dos profissionais de saúde entrevistados também afirmaram que sua formação acadêmica não aconteceu de forma interdisciplinar, assim como encontrado em nosso estudo.

Nos resultados apresentados nesta investigação, alguns participantes mencionaram o contato que tiveram com a interdisciplinaridade e a interprofissionalidade em sua formação apenas de maneira teórica, com a discussão dos temas em sala de aula e a leitura de artigos e textos sobre a atuação de outros profissionais.

De acordo com Hays (2013), oferecer estas leituras aos estudantes não é eficiente se os aspectos discutidos não forem vivenciados e experimentados na prática. É preciso que estes estudantes tenham oportunidade de treinamentos e vivências práticas em sua formação, bem como os resultados destes treinamentos serem acompanhados pelas instituições (Clark, 1993).

Os projetos pedagógicos dos cursos da área da saúde, de maneira geral, mostram preocupação com a formação deste profissional, para que ele possa adquirir "competência técnico-científica, visão crítica, reflexiva e humanista, com compreensão das necessidades individuais e coletivas do conjunto social, com capacidade para trabalhar em equipe, articulando e integrando conhecimento com as demais categorias profissionais" (Gattás, 2006, p. 39).

Em virtude do fato de haverem formações acadêmicas e profissionais tão heterogêneas em relação à interdisciplinaridade e interprofissionalidade, acreditamos que o papel de treinamento e capacitação destes profissionais quanto às melhores práticas de atendimento à população idosa, também competem à instituição de saúde que objetiva oferece-las. De acordo com Costa (2002), 
"A construção de novos projetos não pode advir de esforços solitários dos profissionais. Ela deve ser alicerçada pelo apoio institucional, que deve possibilitar espaço de autonomia e criatividade para os profissionais, alavancando o processo de qualificação e formação de equipes no interior dos serviços. Para isso, é necessário romper com a prática histórica de apoio ao corporativismo e inovar as práticas de gestão (Costa, 2002, p. 85).

Desta forma, torna-se preciso romper com a lógica capitalista da produção nas instituições, evitando que o trabalho destes profissionais fique pautado apenas na produção e competitividade, na prestação de serviço mecânica e massificada, esvaziada de conteúdo e valores humanos (Oliniski, Lacerda, 2004).

O desconhecimento dos conceitos de interdisciplinaridade e interprofissionalidade por parte dos participantes do estudo também apareceu como fator de destaque nos resultados, principalmente relacionado aos discursos dos profissionais com mais tempo de atuação na área de Geriatria e Gerontologia.

De acordo com Pombo (1994), a dificuldade em compreender e definir o significado do conceito interdisciplinaridade reside na maneira como estes profissionais foram formados e capacitados, como eles atuam em seu cotidiano e como este conceito faz parte das atitudes destes profissionais. As palavras da autora, fazem-nos refletir sobre o contato real que estes profissionais tiveram com os conceitos em sua formação e como de fato os aplicam em sua prática cotidiana.

Mosser e Begun (2015) afirmaram que a segregação dos estudantes durante a sua formação evita que eles aprendam a trabalhar em equipes interprofissionais, fazendo com que atuem mais individualmente quando começam a exercer sua profissão. 
Souza et al (2012) verificaram que ações interdisciplinares são viáveis no ensino superior, desde que seus gestores institucionais sejam compromissados em efetuar as mudanças necessárias, que o Projeto Político Pedagógico da instituição contemple essa orientação e que conte com alguém que articule as ações neste sentido.

Apenas com os discursos dos participantes que apresentaram alguma dificuldade na definição e reconhecimento dos conceitos não é possível afirmar de fato se os mesmos apresentam realmente as atitudes características da interdisciplinaridade e da interprofissionalidade em sua prática profissional com idosos. Entretanto, outros participantes de nosso estudo trazem sem seus relatos situações práticas de seu cotidiano onde experimentam a interdisciplinaridade e a interprofissionalidade.

Assim como pudemos observar no trabalho presente, no estudo de Leite e Veloso (2008), que entrevistaram 24 profissionais do Programa Saúde da Família, os participantes também apresentaram dificuldades em definir a interdisciplinaridade e o trabalho em equipe, mas reconhecem a importância destas práticas. Os autores acabaram concluindo em suas análises que estas abordagens não se efetivavam de fato na prática dos profissionais participantes do estudo.

A mesma dificuldade em conceituar a interdisciplinaridade apareceu no estudo de Souza e Souza (2009), onde os profissionais também apresentaram insegurança em relação à estas práticas e demonstraram em suas ações ter uma prática mais próxima da multiprofissionalidade do que da interdisciplinaridade. Da mesma forma que aparece em nossos resultados, os profissionais do estudo de Souza e Souza (2009) também conseguem reconhecer a importância da interdisciplinaridade para as suas práticas em saúde. De acordo com as autoras, 
"A prática da interdisciplinaridade exige intensa articulação entre os especialistas e interação real das disciplinas, através de relações de interdependência e de conexões recíprocas, de horizontalização de saberes, o que não deve ser confundido com simples trocas de informações" (Souza, Souza, 2009, p. 120).

No trabalho de Scherer et al (2013), as entrevistas com os profissionais a respeito da interdisciplinaridade também mostraram-na como possibilidade concreta no plano intelectual, mas na prática o trabalho era orientado predominantemente pelo modelo biomédico hegemônico.

De acordo com Gadamer (2009), todas as decisões práticas do homem dependem de seu conhecimento geral, porém a aplicação concreta destes conhecimentos é uma questão de discernimento, já que o profissional usará da conveniência da aplicação destes conhecimentos na prática. Tal decisão diz respeito à responsabilidade de cada um. O interesse teórico por si só não basta, "quando o funcionamento da própria técnica tem um elevado custo baseado na divisão do trabalho" (Gadamer, 2009, p.37).

Assim, conforme Gadamer (2009), temos que aprender a estender uma ponte entre o teórico, que sabe das generalidades, e o prático, que deve modificar a situação do paciente que necessita de cuidado.

Convém salientar, em relação aos participantes que tem dificuldades em definir os conceitos, principalmente devido ao tempo de atuação destes profissionais na área, a necessidade de atualização constante, como compromisso ético e de responsabilidade destes profissionais (Souza, Souza, 2009).

Segundo Gadamer (2009), tal compromisso ético reside na obrigação de se saber tudo na medida do possível, o que significa estar informado pela ciência. $\mathrm{O}$ 
filósofo também destacou que a relevância desta aproximação com a ciência para que se evite a autonomização que se produz nas profissões práticas. Compreende-se aqui por autonomização a liberdade no sentido negativo, isto é, como independência em relação a qualquer coacção exterior, o que afastaria este profisisonal de novas práticas e outros pontos de vista. Ainda neste sentido, destacamos a posição de Scherer, que afirmou:

Um contexto como o da pesquisa vai exigir mais do coletivo e pode dificultar a cristalização de experiências, processos esses nem sempre visíveis, difíceis de avaliar, mas que muitas vezes aparecem como sendo resistências dos trabalhadores às mudanças (Scherer et al, 2013, p. 3210).

Assim, vemos como se torna importante a atualização profissional. Entretanto, Gadamer (2009) nos lembra que não basta a aquisição teórica de conhecimentos, pois a decisão prática diz respeito a responsabilidade de cada um. A complexidade da atenção à saúde exige o engajamento do profissional, a capacidade de escuta, o compromisso ético e a visão integral do sujeito do cuidado (Scherer et al, 2013).

Jonas (2013), nos disse que a técnica é uma forma de ação, e toda forma de ação humana está sujeita a uma avaliação moral. Pressupõe-se que a ética pode distinguir entre o uso correto ou errado de uma técnica, neste sentido o autor afirma: "utilize este poder, aumente-o, mas não faça mau uso dele" (Jonas, 2013, p.52).

Como seria possível obter o sucesso no aprendizado destes profissionais? A resposta para este sucesso pode estar nos princípios da Andragogia, que nos afirmaram que este sucesso estaria relacionado aos meios adequados para apresentação e discussão de conteúdos com informações que produzam adaptações ou modificações voluntárias do comportamento nestes profissionais. Seria necessário o uso de estratégias adequadas para favorecer a assimilação do conhecimento, 
desenvolvimento de habilidades e incorporação de valores, de forma a favorecer a aprendizagem dos profissionais nessas áreas, seja na formação profissional ou na educação permanente (Draganov et al, 2011).

Importante destacarmos a questão da educação permanente, prevista na Política Nacional de Educação Permanente em Saúde, que tem como proposta a melhoria da qualidade da assistência no Sistema Único de Saúde e se alicerça na premissa de que o conhecimento não se transmite, mas se constrói a partir das dúvidas e do questionamento das práticas vigentes à luz dos problemas contextuais. Ela inclui a busca de formação no trabalho de equipe, a integração das dimensões cognitivas, de atitudes e competências práticas (Brasil, 2009).

Os processos de educação permanente em saúde visam o desenvolvimento de novas competências específicas e compartilhadas, servindo como meio para a transformação da cultura do trabalho (Medeiros, 2015).

Este desafio requer ainda que não só os profissionais envolvidos sejam responsáveis, mas, também há uma responsabilidade dos gestores, que devem demonstrar o interesse para a promoção de uma prática colaborativa que atenda às necessidades de saúde dos indivíduos cuidados (Rocha et al, 2016).

Apresentaremos a seguir os fatores apresentados pelos profissionais e que podem contribuir para a melhora do trabalho em equipe no atendimento de idosos.

\subsection{Como melhorar as ações integradas no cotidiano de trabalho com idosos}

Após estas reflexões, temos que abordar uma das questões mais importantes deste trabalho. Como de fato podemos articular as ações de ensino, formação profissional e ações institucionais para que realmente o idoso possa ser considerado em sua complexidade nas ações de saúde. 
Reforçamos que o discurso sobre os benefícios da interdisciplinaridade e da interprofissionalidade na Gerontologia, apresentados pelos participantes deste estudo, não podem permanecer apenas no campo das ideias. São necessárias atitudes destes profissionais, seus gestores e das instituições para que estes conceitos se traduzam de fato na prática cotidiana em saúde do idoso. Ao mesmo tempo, deve-se investir na formação destes profissionais, seja com a inclusão de conteúdos sobre envelhecimento e trabalho em equipe nos cursos de graduação, pósgraduação latu e strictu sensu, bem como na disponibilização destas vivencias práticas durante a formação destes profissionais.

A disseminação do conhecimento sobre gerontologia, interdisciplinaridade, interprofissionalidade e trabalho em equipe na saúde deve ser estimulada em todos as camadas que perpassam este cuidado ao idoso, como por exemplo:

- troca de conhecimentos na interação entre os diferentes profissionais: espaços de troca são de extrema importância, como foi possível observar na fala dos participantes do estudo, principalmente as discussões de caso clínico e reuniões.

- treinamentos e capacitações oferecidos pelas instituições de saúde: outro fator destacado na fala dos participantes.

- estimulação da produção científica na área de gerontologia: para que as experiências possam ser compartilhadas, pois as equipes de saúde podem se tornar disseminadoras de informação, funcionando como um repositório de conhecimento útil (Mosser, Begun, 2015).

Se uma nova possibilidade foi uma vez aberta e desenvolvida em pequena escala, é próprio dela então forçar sua aplicação em grande escala, bem como fazer dessa aplicação uma necessidade vital permanente. Uma vez desenvolvidas, tais 
capacidades já não podem mais ser abandonadas, a não ser mediante a uma substituição superior (Jonas, 2013).

Em relação à fala de um dos participantes, que reforça a necessidade do profissional ter domínio e clareza de seu papel, tal fato pode ser ilustrado na fala de Gadamer (2009), ao afirmar que "quem domina a sua arte não precisa de demonstrar sua superioridade nem a si mesmo e nem aos outros" (p. 33). Quanto maior a segurança do profissional em dominar a sua arte, mais liberdade ele terá em relação a ela.

Os profissionais devem ser formados com perfil adequado para atender as necessidades sociais, o que implica um profissional mais ativo, dinâmico, que saiba buscar conhecimento, com visão integral do ser humano, com uma ampliação do conceito de saúde-doença-cuidado, com habilidades pessoais para trabalho em equipe e as relações interpessoais, agilidade diante do inesperado, capacidade de tomar decisões e de propor ações de auto-organização. De acordo com Gattás (2006), estas são as características que se esperam dos profissionais do futuro.

O conceito de competência pode ser estendido ao trabalho em equipe, sendo estas aptidões, conhecimento e valores Mosser e Begun (2015).

Correlacionaremos abaixo a fala dos participantes do estudo com os aspectos apontados por Mosser e Begun (2015), a respeito das mudanças necessárias para melhorar o trabalho em equipe na saúde:

- os profissionais de saúde precisam compreender o trabalho de seus colegas: como é possível ver na percepção dos participantes do nosso estudo, conhecer o trabalho do outro aumenta a confiança e a colaboração entre os profissionais. 
- os administradores de saúde devem tornar-se membros da equipe: da mesma maneira, surge na fala de um dos participantes a importância de seus superiores compreenderem a relevância do trabalho em equipe colaborativo.

- as equipes devem tornar-se menos hierárquicas: as questões sobre hierarquia também foram mencionadas pelos participantes do estudo, gerando o medo e o receio da aproximação entre estes profissionais.

- os papéis dos médicos estão mudando e devem mudar: de acordo com os autores, os médicos compreendem uma das profissões que mais dificulta o trabalho em equipe na saúde. A dificuldade de acesso aos profissionais da medicina também aparece na fala dos participantes, por vezes, com o médico adotando o papel centralizador das ações em saúde, não compartilhando e colaborando com as ações da equipe. É necessário que todos os membros da equipe tenham como característica a interdependência de suas ações. Os mesmos fatores em relação à integração com os médicos também aparecem no estudo de Scherer et al (2013).

Os participantes do estudo nos falaram sobre a importância do vínculo e a confiança estabelecida entre os profissionais que já se conheciam há muito tempo para o desenvolvimento da interdisciplinaridade e da interprofissionalidade. Nessa linha de pensamento, Mosser e Begun (2015), os membros de uma equipe que ficam juntos por muito tempo podem desenvolver forte sentido de identificação com o grupo e seus objetivos, percebendo a equipe como um reflexo de si mesmos. A medida que esta confiança se desenvolve, os membros da equipe tornam-se mais interdependentes e mais seguros em relação ao trabalho dos colegas.

Como apresentado nos resultados deste estudo, foi possível ver que os participantes possuíam certo grau de diferenciação em suas formações e tempo de experiências. De acordo com Mosser e Begun (2015), para que uma equipe com 
profissionais muito diferenciados produza processos e resultados de alta qualidade, é de suma importância que a integração seja alcançada. Os autores apresentaram a "compreensão cruzada" como uma maneira de alcançar tal integração. Esta compreensão se trata da forma como os membros da equipe alcançam grande compreensão dos modelos mentais uns dos outros, o que aprofundaria e enriqueceria a qualidade da comunicação e a interpretação da contribuição de cada membro para o grupo.

A troca de informações entre os diferentes profissionais, mencionada pelos participantes do estudo, nos leva aos aspectos referentes a comunicação em saúde. Ter habilidade de se comunicar de forma interdisciplinar, implica na existência do diálogo, respeito e empatia pelo outro, sendo este último, considerado extremamente relevante, pois exige um agir com empatia e paciência, além do respeito à individualidade e a peculiaridade de cada um, sua autonomia, seu direito de agir e pensar diferente (Souza, Souza, 2009).

$\mathrm{Na}$ relação profissional que busca a interdisciplinaridade e a interprofissionalidade, os profissionais necessitam conhecer novos vocabulários. O objetivo não é ser um especialista em todas as áreas do conhecimento, mas sim, compreender os demais especialistas e fazer questionamentos pertinentes. A construção deste vocabulário comum requer tempo e comprometimento por parte dos profissionais, além do respeito e desejo de aprender um com o outro (Silver, Leslie, 2009; Parrot, Kreuter, 2011).

A ausência de um vocabulário comum aos profissionais de gerontologia mostrou-se como uma barreira para a implementação de atitudes interdisciplinares no grupo de profissionais avaliados no estudo de Légaré et al (2013). 
Sabemos que a interdisciplinaridade só se faz na intencionalidade, que se baseia no plano institucional, mas também e principalmente no desejo de cada profissional. O desejo de saber de cada um, seu diálogo particular com sua disciplina permitirá a ele transitar pelos diversos saberes encontrados no interior das instituições ou o imobilizará em um saber engessado e uma prática estéril (Costa, 2002).

É preciso que as experiências destes profissionais, que se transformaram em tecnologias não se cristalizem como tal, devendo ser permeáveis à mudança, ao novo, à reconstrução. Sendo assim, a responsabilidade se torna fundamental, pois o modo de agir no mundo destes profissionais os tornam responsáveis pelas práticas de cuidado que oferecem (Ayres, 2009). Além disso, "as exigências sobre a responsabilidade crescem proporcionalmente aos feitos do poder" (Jonas, 2013).

O desenvolvimento de habilidades interprofissionais e de colaboração deve contemplar alguns aspectos, como o conhecimento sobre a interprofissionalidade, dinâmicas de grupo, as competências para atuar em equipe e as habilidades necessárias para trabalhar de maneira colaborativa, com especial foco nas habilidades para uma comunicação efetiva (Silver, Leslie, 2009; Gjorgjeska, 2012).

Pensando nos profissionais que exercem sua atuação em saúde do idoso, além dos aspectos apresentados acima, também torna-se essencial a inclusão de temas centrais da Geriatria e Gerontologia no treinamento destes profissionais (Solberg et al, 2015).

Sendo assim, esta discussão nos apresenta a necessidade de ações em vários sentidos, mas em especial, devemos refletir sobre o papel institucional e dos profissionais na construção de melhores práticas para a atuação em saúde do idoso. O cotidiano destas práticas nos revela as suas diferentes nuances e pode se tornar fonte rica para aprendizado e reflexão. 


\section{Limitações}

Este estudo não fez uma observação direta do trabalho em equipe desenvolvido por estes profissionais. Mantemos o foco em compreender como tais processos se dão, apenas do ponto de vista da fala destes profissionais, esclarecido por meio das técnicas explicadas no item Método. Também devemos esclarecer que o local escolhido para a coleta de dados é referência na atuação em Geriatria e Gerontologia e que 52\% dos participantes do estudo possuem pós-graduação na área de envelhecimento, o que pode não corresponder a realidade de outros serviços de saúde do idoso. 


\section{Considerações finais}

A importância deste trabalho reside na medida que se almejam as melhores práticas gerontológicas, para que os princípios preconizados no Sistema Único de Saúde, nas Políticas Públicas de saúde do idoso e no amplo referencial teórico da Geriatria e Gerontologia possam de fato chegar ao alvo destas preocupações: o ser idoso em sua complexidade. Esperamos que as falas destes profissionais, que vivenciam o cotidiano das práticas em saúde do idoso, a partir de nossa análise e discussão, possam contribuir para que as ações de educação profissional e prestação de serviços de saúde aos idosos possam ser repensadas, ampliadas e transformadas. O dinamismo do conhecimento gerontológico exigirá cada vez mais a agilidade destes profissionais em se atualizar e refletir sobre suas práticas. Perpetuar práticas cristalizadas e engessadas vai na contramão do cuidado em seu sentido real.

Entendemos, a partir da fala dos participantes e do amplo debate encontrado na literatura, que mudanças na formação dos profissionais de saúde para o desenvolvimento de competências em geriatria e gerontologia e para o trabalho interprofissional são extremamente necessárias. Não basta apenas a aproximação teórica aos temas, são fundamentais as vivências práticas que os coloquem no desafio cotidiano do contato e das trocas com outros profissionais.

O treinamento e educação permanente dos profissionais de saúde que atuam no envelhecimento também são de extrema relevância, uma vez que nem todos terão o mesmo contato com o envelhecimento e o trabalho em equipe em suas formações. A instituição que deseja oferecer boas práticas de cuidado ao idoso necessita ter um olhar atento ao treinamento constante destes profissionais, bem como a avaliação dos resultados destes treinamentos na prática do serviço, observando se tais práticas de fato incorporaram as mudanças necessárias. 
Não podemos esquecer a grande responsabilidade deste profissional em se manter atualizado e alinhado com as práticas mais atuais em Geriatria e Gerontologia, assumindo o compromisso ético de prestar um cuidado de qualidade e efetivo. Mesmo que estes profissionais reconheçam a importância da interdisciplinaridade e da interprofissionalidade em sua atuação com idosos, isto não significa que de fato estes conceitos estejam incorporados em sua prática. Barreiras e facilitadores à incorporação destes na prática precisam ser observados pelas instituições, gestores e líderes, que devem manter um olhar atento aos serviços de saúde oferecidos aos idosos. A escuta destes profissionais a respeito destes facilitadores e limitadores pode ser tornar um bom meio de coleta de informações a respeitos das vivências na equipe, o que pode auxiliar estes gestores a repensar e reformular as práticas desenvolvidas na instituição.

Destacamos ainda a importância da divulgação científica das vivências destes profissionais que atuam em Geriatria e Gerontologia, pois o cotidiano de suas práticas com o idoso pode servir de modelo para que outras instituições ou profissionais reexaminem os serviços que oferecem, pois "o produzir adquire justamente a sua perfeição, ao criar algo e oferecê-lo para ser usado por outros" (Gadamer, 2009. P.46). Lembrando sempre que é preciso existir espaços de acontecimento, para que os profissionais possam de fato ter o contato uns com os outros e possam se estabelecer o vínculo e a relação de confiança tão destacados pelos participantes deste estudo e também referenciados na literatura.

A Gerontologia caminha cada vez mais no sentido de se tornar uma ciência transdisciplinar, o que implica que os profissionais que atuam dentro dela, precisam caminhar no mesmo sentido. A interdisciplinaridade é uma aspiração crescente no seio dos profissionais que atuam em Gerontologia. Isto quer dizer que a mudança 
desejada seria no sentido da produção de modelos complexos, de determinação complexa (Fragoso, Mayor, 2017). Assim,

Desejamos laços que permitam uma melhor compreensão e atuação perante 0 envelhescente. Laços que permitam uma melhor comunicação entre profissionais e suas disciplinas de especialidade, para que o conhecimento seja cada vez mais globalizante, integrador e transdisciplinar, fundado numa verdadeira ética que nos leva a uma efetiva Ecologia dos Saberes (Fragoso, Mayor, 2017, p. 16).

O profissional da Gerontologia não poderá se tornar um especialista "monotemático", fixado e arraigado em um único tema de interesse. O conhecimento precisa ser globalizado, capaz de abarcar a complexidade do ser que envelhece e de dialogar com os outros especialistas, sem a visão das linhas que os separam. A Gerontologia como campo de saber que estuda o processo de envelhecimento como um todo e pela sua natureza inter e transdisciplinar pode auxiliar na criação de uma perspectiva global e dialogante entre as várias ciências e saberes que para ela contribuem e, através desse entrecruzamento de saberes, sair mais enriquecida e ampliada (Fragoso, Mayor, 2017).

Mais pesquisas a respeito do tema interdisciplinaridade e interprofissionalidade na Gerontologia são necessárias, principalmente no sentido do acompanhamento da formação e da atuação destes profissionais, se possível, acompanhando as diferentes realidades das instituições que oferecem serviços de saúde ao idoso. Entendemos que ainda há muito por fazer no que se refere à transferência efetiva de conhecimento em benefício dos idosos e sociedade em geral, mas o caminho está a nossa frente e não podemos ignorá-lo. 


\section{Referências}

ARAÚJO, M.B.S.; ROCHA, P.M. Trabalho em equipe: um desafio para a consolidação da estratégia de saúde da família. Ciência \& Saúde Coletiva, 12(2):455-464, 2007.

AYRES, J. R. C. M. O cuidado, os modos de ser (do) humano e as práticas de saúde. Saúde e Sociedade, v. 13, n. 3, p. 16-29, set-dez 2004.

AYRES, J.R.C.M. Cuidado: trabalho e interação nas práticas de saúde. $1^{\text {a }}$ Edição, CEPESC - IMS/UERJ - ABRASCO, Rio de Janeiro, 2009. 282 P.

BARKER, E.; VOLLAND, P. J.; WRIGHT, M. E. Education of the interdisciplinary team. In: SCHRAEDER, C.; SHELTON, P. Comprehensive Care Coordination for Chronically III Adults. John Wiley \& Sons Inc. $1^{\underline{a}}$ ed. 2011. Cap. 9.

BRASIL. Constituição da República Federativa do Brasil. Brasília, DF: Senado; 1988.

BRASIL. Diário Oficial da União. Lei № 8080/90. Dispõe sobre as condições para a promoção, proteção e recuperação da saúde, a organização e o financiamento dos serviços correspondentes e da outras providências. Brasília, DF, 19 de Setembro, 1990.

BRASIL. Política Nacional do Idoso: Lei 8.842 de 04/01/1994- Brasília: MPAS, SAS, 1994.

BRASIL. Lei no 1074/2003. Estatuto do Idoso. Brasília: DF, Outubro de 2003.

BRASIL. Ministério da Saúde. Portaria oㅜ 2.528 de 19 de Outubro, 2006, aprova a Política Nacional de Saúde da Pessoa Idosa. Brasília, DF. 2006. <disponível em http://www.saudeidoso.icict.fiocruz.br/pdf/PoliticaNacionaldeSaudedaPessoaldosa.pd f>

BRASIL. Ministério da Saúde, Secretaria de Gestão do Trabalho e da Educação na Saúde, Departamento de Gestão da Educação em Saúde. Política Nacional de Educação Permanente em Saúde. Brasília: Ministério da Saúde, 2009. 64 p.

CACHIONI, M.; NERI, A.L. Educação e gerontologia: desafios e oportunidades. Revista Brasileira de Ciências do Envelhecimento Humano, Passo Fundo, 99115 - jan./jun. 2004 
CAMACHO, A.C.L.F. A gerontologia e a interdisciplinaridade: aspectos relevantes para a enfermagem. Revista Latino-americana de Enfermagem, 2002, maio-abril; 10(2):229-33.

CÂMARA, A.M.C.S.; CYRINO, A.P.; CYRINO, E.G.; AZEVEDO, G.D.; COSTA, M.V.; BELLINI, M.I.B.; PEDUZZI, M.; BATISTA, N.A.; BATISTA, S.H.S.S.; REEVES, S. Educação interprofissional no Brasil: construindo redes formativas de educação e trabalho em saúde. Revista Interface. 2016; 20(56):9-12.

CAVALCANTE, R.B.; CALIXTO, P.; PINHEIRO, M.M.K. Análise de conteúdo: considerações gerais, relações com a pergunta de pesquisa, possibilidades e limitações do método. Inf. \& Soc.:Est., João Pessoa, v.24, n.1, p. 13-18, jan./abr. 2014.

CLARK, P.G. Leraning on interdisciplinary gerontological teams: instructional concepts and methods. $19^{\text {th }}$ Annual Metting of the Association for Gerontology in Higher Education, Louisville, March 1993.

CLEAVELAND, M.; HOLDER, C.; KHAN, A.; JENCIUS, A. The team approach to interdisciplinary care. In: MALONE, M. L.; CAPEZUTI, E. A.; PALMER, R. M. Acute car for elders: a model for interdisciplinary care. New York: Springer, 2014. p. 920.

COIMBRA, J. A. A. Considerações sobre a Interdisciplinaridade. In: PHILIPPI JR., A.; TUCCI, C. E. M.; HOGAN, D. J.; NAVEGANTES, R. Interdisciplinaridade em Ciências Ambientais. São Paulo: Signus, 2000, p. 52-70

COSTA, R.P. Interdisciplinaridade e equipes de saúde: concepções. Mental, ano V - n. 8 - Barbacena - jun. 2007 - p. 107-124.

COSTA, R.P. Interdisciplinaridade e equipes de saúde: um estudo de caso. Dissertação de mestrado. Florianópolis, 2002.

COSTA, M.V. A educação interprofissional no contexto brasileiro: algumas reflexões. Revista Interface. 2016; 20(56):197-8.

DRAGANOV P.B.; FRIEDLÄNDER, M.R.; SANNA, M.C. Andragogia na saúde: estudo bibliométrico. Esc Anna Nery, 2011 jan-mar; 15 (1):149-156.

DRINKA, Theresa J. K.; CLARK, Philipe G. Interdisciplinary: practice and teaching. Westport: Greenwood, 2000.

ELLERY, A.E.L. Interprofissionalidade na Estratégia de Saúde da Família: condições de possibilidade para a integração de saberes e colaboração 
interprofissional. 256f. Tese (Doutorado em Saúde Coletiva) - Faculdade de Medicina, Universidade Federal do Ceará. Fortaleza, 2012.

ETGES, N.J. Ciência, interdisciplinaridade e educação. In: JANTSCH, A.P.; BIANCHETTI, L. (Org.). Interdisciplinaridade: para além da filosofia do sujeito. 9a ed. Ed. Vozes. 2011.

FAZENDA, I. C. A. Interdisciplinaridade: um projeto em parceria. São Paulo: Loyola, 2002

FAZENDA, I. C. A. Integração e Interdisciplinaridade no Ensino Brasileiro: efetividade ou ideologia. São Paulo: Loyola, 1979.

FRAGOSO, V.; MAYOR, M.S. (Org.). Gerontologia e transdisciplinaridade I. $1^{\underline{a}}$ ed., Portal Edições, São Paulo, 2017, 250 p.

FRIGOTTO, G. A interdisciplinaridade como necessidade e como problema nas ciências sociais. In: JANTSCH, A.P.; BIANCHETTI, L. (Org.). Interdisciplinaridade: para além da filosofia do sujeito. 9ª ed. Ed. Vozes. 2011.

FURTADO, J.P. Arranjos Institucionais e Gestão da Clínica: Princípios da Interdisciplinaridade e Interprofissionalidade. Cadernos Brasileiros de Saúde Mental, Vol 1, no1, jan-abr. 2009.

GADAMER, H.G. O mistério da saúde: o cuidado da saúde e a arte da Medicina. Editora 70. Lisboa, 2009. $192 \mathrm{p}$.

GALERA, S.C. O ensino do envelhecimento precisa amadurecer. Editorial. Revista Brasileira em Promoção da Saúde, Fortaleza, 24(3): 189-190, jul./set., 2011

GATTÁS, M.L.B. Interdisciplinaridade: formação e ação na área da saúde. Holos Editora, Ribeirão Preto, 2006, 200 p.

GJORGESKA, B. Interprofessional and tem-based continuing education for health professionals. European Medical, Health and Pharmaceutical Journal, Vol. 4, 2012.

GONDIM, S.M.G. Grupos focais como técnica de investigação qualitativa: desafios metodológicos. Paidéia, 2003, 12(24), 149-161.

GOULD, C.E.; EDELSTEIN, B. A.; GEROLIMATOS, L.A. Assessment of Older Adults. In: WHITBOURNE, S. K.; SLIWINSKI, M. J. The Wiley-Blackwell Handbook of Adulthood and Aging. First Edition. 2012. Blackwell Publishing Ltd. Cap. 17. 
GUIMARÃES, L.D.; PINTO, M.P. Análise quantitativa do termo interdisciplinaridade no período de 1970 a 2004. Multiciência: tecnologia para a saúde. Outubro. 2005.

HAYS, R. Interprofessional education. John Wiley \& Sons Ltd. The clinical teacher, 2013; 10: 338-341.

JACOB FILHO, W. Interdisciplinaridade. In: JACOB FILHO, W.; KIKUSHI, E. L. Geriatria e gerontologia básicas. Rio de Janeiro, 2011. p. 19-30

JANTSCH, A.P.; BIANCHETTI, L. Interdisciplinaridade - para além da filosofia do sujeito. In: JANTSCH, A.P.; BIANCHETTI, L. (Org.). Interdisciplinaridade: para além da filosofia do sujeito. 9ª ed. Ed. Vozes. 2011.

JAPIASSU, H. Interdisciplinaridade: a patologia do saber. Rio de Janeiro: Imago; 1976.

JONAS, H. Técnica, medicina e ética: sobre a prática do princípio responsabilidade. São Paulo, Paulus, 2013, 328 p.

LÉGARÉ, F.; STACEY, D.; BRIÈRE, N.; FRASER, K.; DESROCHES, S.; DUMONT, S.; SALES, A.; PUMA, C.; AUBÉ, D. Healthcare providers' intentions to engage in an interprofessional approach to shared decision-making in home care programs: A mixed methods study. Journal of Interprofessional Care, 2013, 27: 214-222.

LEITE, R.F.B.; VELOSO, T.M.G. Trabalho em equipe: representações sociais de profissionais do PSF. Psicol Cienc Prof. 2008; 28(2): 374-389.

LEMOS, N.F.D.; TOBIAS, M.A.; LUIZ, C.; BESSE, M.; Interdisciplinaridade, saúde e gerontologia. Revista Equilíbrio Corporal e Saúde, 2012;4(1)3-8.

LODOVICI, F. M. M.; SILVEIRA, N. D. R. S. Interdisciplinaridade: desafios na construção do conhecimento gerontológico. Estudos interdisciplinares sobre o envelhecimento, Porto Alegre, v. 16, n. 2, p. 291-306, 2011.

LOPES, A. A Sociedade Brasileira de Geriatria e Gerontologia e os desafios da Gerontologia no Brasil. Dissertação de mestrado. Campinas, 2000.

MARTINS DE SÁ, J.L. A formação profissional em Gerontologia. In: FREITAS, E.V. et al. Tratado de Geriatria e Gerontologia. $3^{a}$ edição. Rio de Janeiro: GuanabaraKoogan, 2011. Cap. 155.

MATOS, E.; PIRES, D.E.P.; SOUSA, G.W. Relações de trabalho em equipes interdisciplinares: Contribuições para novas formas de organização do trabalho em saúde. Revista Brasileira de Enfermagem, Brasília, 2010, set-out; 63(5):775-81. 
MEDEIROS, N.M.H. Educação permanente em saúde: gestão do ensino na concepção dos trabalhadores. Editora FAP-UNIFESP. São Paulo, 2015, 240 p.

MENDES, J.M.R; LEWGOY, A.M.B.; SILVEIRA, E.C. Saúde e interdisciplinaridade: mundo vasto mundo. Revista Ciência \& Saúde, Porto Alegre, v. 1, n. 1, p. 24-32, jan-jun. 2008.

MESQUITA, R.A.V.; COSTA, N.E.; CARVALHO, H.B.C. Políticas públicas de saúde para o envelhecimento e a velhice. In: FREITAS, E.V. et al. Tratado de Geriatria e Gerontologia. 3ª edição. Rio de Janeiro: Guanabara-Koogan, 2011. Cap. 148.

MILLER, P. A. Interdisciplinary teamwork: the key to quality care for older adults. In: TEPPER, L. M. ; CASSIDY, T.M. Multidisciplinary Perspectives on Aging. Nova York, 2004, Spring Publishing Company.

MINAYO, M.C.S. (Org.). Pesquisa social: teoria, método e criatividade. Rio de Janeiro: Vozes. 2001.

MINAYO, M.C.S. O desafio do conhecimento: pesquisa qualitativa em saúde. Ed. Hucitec, 12 ${ }^{\mathrm{a}}$ edição. 2010.

MINAYO, M.C.S. Disciplinaridade, interdisciplinaridade e complexidade. Emancipação, Ponta Grossa, 10(2): 435-442, 2010. Disponível em http://www.revistas2.uepg.br/index.php/emancipacao

MOSSER, G.; BEGUN, J.W. Compreendendo o trabalho em equipe na saúde. AMGH Editora, Porto Alegre, 2015. $316 \mathrm{p}$.

MOTTA, L. B.; AGUIAR, A. C. Novas competências profissionais em saúde e o envelhecimento populacional brasileiro: integralidade, interdisciplinaridade e intersetorialidade. Ciência \& Saúde Coletiva, 12(2):363-372, 2007.

MUELLER, R.R.; BIANCHETTI, L.; JANTSCH, A.P. Interdisciplinaridade, pesquisa e formação de trabalhadores: as interações entre o mundo do trabalho e da educação. In: JANTSCH, A.P.; BIANCHETTI, L. (Org.). Interdisciplinaridade: para além da filosofia do sujeito. 9 ${ }^{a}$ ed. Ed. Vozes. 2011.

NERI, A.L. (Org.) Palavras-chave em Gerontologia. Campinas, Editora Alínea, $4^{a}$ edição, 2014.

OLINISKI, S.R.; LACERDA, M.R. A diferentes faces do ambiente de trabalho em saúde. Cogitare Enfermagem. 2004, jul-dez. 9(2):43-52. 
PAPALÉO NETTO, M. O estudo da velhice: histórico, definição do campos e termos básicos. In: FREITAS, E.V. et al. Tratado de Geriatria e Gerontologia. 3ª edição. Rio de Janeiro: Guanabara-Koogan, 2011. Cap. 1.

PARROT, R.; KREUTER, M.W. Multidisciplinary, interdisciplinary and transdisciplinary approaches to health communication: where do we draw the lines? In: THOMPSON, T.L.; PARROT, R.; NUSSBAUM, J.F. The Routledge Handbook of Health Communication. Routledge. Second edition. New York, 2011.

PAVARINI, S.C.I.; DE MENDIONDO, M.S.Z.; BARHAM, E.J.; VAROTO, V.A.G.; FILIZOLA, C.L.A. A arte de cuidar do idoso: a gerontologia como profissão. Texto Contexto Enferm., 2005 Jul-Set; 14(3):398-402.

PEDUZZI, M.; NORMAN, I.J.; GERMANI, A.C.C.G.; SILVA, J.A.M.; SOUZA, G.C. Educação interprofissional: formação de profissionais de saúde para o trabalho em equipe com foco nos usuários. Revista da Escola de Enfermagem USP, 2013; 47(4):977-83.

POMBO, O. A interdisciplinaridade: conceito, problema e perspectivas. In: GUIMARÃES, H.M.; POMBO, O.; LEVY, T. (Org.). A interdisciplinaridade: reflexão e experiência. $2^{\underline{a}}$ ed. Lisboa: Texto, 1994.

ROCHA, F.A.A.; BARRETO, I.C.H.C.; MOREIRA, A.E.M.M. Colaboração interprofissional: estudo de caso entre gestores, docentes e profissionais de saúde da família. Interface. 2016; 20(57):415-2.

RODRIGUES, M.L. Caminhos da Transdisciplinaridade: fugindo a injunções lineares. Revista Serviço Social e Sociedade, No.64, Ano XXI, São Paulo, Ed. Cortez, Nov/2000. <disponível em http://www.pucsp.br/nemess/links/artigos/marialucia3.htm>, acessado em 25/10/2015.

REEVES, S. Porque precisamos da educação interprofissional para um cuidado efetivo e seguro. Revista Interface. 2016; 20(56):185-96.

REUBEN, D. B. Guidelines, Evidence-Based Medicine, and Glidepaths: Talking the Talk. Editorial. Journal of the American Geriatrics Society. NOVEMBER 2002VOL. 50, NO. 11

SANTOS, N. M. C. Interdisciplinaridade: entre o desejo e a prática dos profissionais do transplante cardíaco no Instituto Dante Pazzanese de Cardiologia. <disponível em:

http://www.google.com.br/url?sa=t\&rct=j\&q=\&esrc=s\&source=web\&cd=1\&cad=rja\&u act=8\&ved=0CB0QFjAA\&url=http $\% 3 \mathrm{~A} \% 2 \mathrm{~F} \% 2 \mathrm{Fcetrans.com}$. br\%2Fartigos $\% 2 \mathrm{FNadja}$ 
Maria_Coda_dos_Santos.pdf\&ei=JiBMVPSmK4XoggSoxoDoBA\&usg=AFQjCNGW zr-8oBv_M8Iw_URz5DF_1OSmUg . Acessado em 25/10/2014.

SAUPE, R.; CUTOLO, L.R.A.; WENDHAUSEN, A.L.P.; BENITO, G.A.V. Competência dos profissionais da saúde para o trabalho interdisciplinar. Interface Comunicação, Saúde, Educação, v.9, n.18, p.521-36, set/dez 200.

SCHERER, M.D.A.; PIRES, D.E.P.; JEAN, R. A construção da interdisciplinaridade no trabalho da Equipe de Saúde da Família. Ciência \& Saúde Coletiva, 18(11):3203-3212, 2013.

SILVA, C.R.S. Interdisciplinaridade e Transdisciplinaridade no atendimento ao idoso. Revista portal de divulgação, n.5, Dez. 2010.

SILVER, I.L.; LESLIE, K. Faculty Development for Continuing Interprofessional Education and Collaborative Practice. Journal of continuing education in the health professions, 29(3):172-177, 2009.

SOLBERG, L.B.; SOLBERG, L.M.; CARTER, C.S. Geriatric care boot camp: an interprofessional education program for healthcare professionals. Journal of American Geriatrics Society, 63:997-1001, 2015.

SOUZA, D.R.P; SOUZA, M.B.B. Interdisciplinaridade: identificando concepções limites para a sua prática em um serviço de saúde. Revista Eletrônica de Enfermagem. 2009; 11(1): 117-123.

SOUZA, M.C.A; CASOTTI, E.; MELLO, A.C.F.; GOYATÁ, F.R.; SOUZA, T.C.; ALBUQUERQUE, C.J.M. Interdisciplinaridade no ensino superior: de imagemobjetivo à realidade! Rev Bras Educ Med. 2012; 36(1): supl.2: 158-163.

TAKAMUR, J.C. Global Challenges for an Aging Population. In: BLACKBURN, J.A.; DULMUS, C.N. Handbook of Gerontology: Evidence-Based Approaches to Theory, Practice, and Policy. 2007, John Wiley \& Sons, Inc. Cap. 20.

TELLES, J. L.; BORGES, A. P. A. Interdisciplinaridade e trabalho em equipe na abordagem da pessoa idosa nos serviços de atenção básica em saúde. In: MALAGUTTI, W.; BERGO, A. M. A. B. Abordagem interdisciplinar do idoso. Rio de Janeiro: Livraria e Editora Rubio, 2010. p. 1-8. 
VOLLAND, P.J.; WRIGH, M.E. Promising practices in integrated care. In: SCHRAEDER, C.; SHELTON, P. Comprehensive Care Coordination for Chronically III Adults. First Edition. John Wiley \& Sons, Inc., 2011. Cap. 4.

XAVIER, A.S.; KOIFMAN, L. Educação superior no Brasil e formação dos profissionais de saúde com ênfase no envelhecimento. Interface - Comunic., Saúde, Educ., v.15, n.39, p.973-84, out./dez. 2011

ZEISS, A.M.; STEFFEN, A.M. Interdisciplinary health care teams: the basic unit of geriatric care. In: CARSTENSEN, L.L.; EDELSTEIN, B.A.; DORNBRAND, L. The pratical handbook of clinical gerontology. Sage Publication Inc. 1996, Cap. 19 


\section{Apêndice A - QUESTIONÁRIO \\ UNIVERSIDADE DE SÃO PAULO \\ ESCOLA DE ARTES, CIÊNCIAS E HUMANIDADES \\ MESTRADO EM GERONTOLOGIA}

Pesquisa: Interdisciplinaridade e interprofissionalidade: percepções dos profissionais envolvidos no atendimento ambulatorial do idoso

Responsável: Bruna Valquiria Baviera

\section{QUESTIONÁRIO - PROFISSIONAL}

DATA:

Profissão:

Gênero:

Idade:

1 - FORMAÇÃO PROFISSIONAL

Graduação:

Ano de conclusão:

Universidade:

Pós-graduação:

( ) Strictu Sensu:

Ano de conclusão:

Instituição:

( ) Latu Sensu:

Ano de conclusão:

Instituição:

Outros cursos:

Número de anos de experiência na atuação em Geriatria e Gerontologia:

1 - Defina, com suas palavras, o que é interdisciplinaridade. 
2 - Defina, com suas palavras, o que é interprofissionalidade.

3 - Você acredita que durante a sua Graduação você teve acesso a conteúdos ou vivências sobre interdisciplinaridade ou interprofissionalidade? Em caso afirmativo, descreva.

4 - Você acredita que durante a sua Pós-graduação você teve acesso a conteúdos ou vivências sobre interdisciplinaridade ou interprofissionalidade? Em caso afirmativo, descreva.

5- Qual é a importância da interdisciplinaridade para a sua atuação profissional?

6 - Qual é a importância da interprofissionalidade para a sua atuação profissional? 


\section{Apêndice B - TERMO DE CONSENTIMENTO LIVRE E ESCLARECIDO}

Convidamos o (a) Sr (a) para participar da Pesquisa "Interdisciplinaridade e interprofissionalidade: percepções dos profissionais envolvidos no atendimento ambulatorial do idoso", sob a responsabilidade da pesquisadora Bruna Valquiria Baviera, estudante do Programa de Mestrado em Gerontologia da EACH USP, sob orientação da Professora Doutora Beatriz Aparecida Ozello Gutierrez.

Sua participação é voluntária e acontecerá por meio de respostas ao questionário integrante dessa pesquisa e posterior participação em grupo focal.

Este trabalho visa contribuir para uma análise das percepções dos profissionais de saúde que atuam com idosos a respeito das suas vivências e experiências em relação à interdisciplinaridade e interprofissionalidade.

Se depois de consentir em sua participação o $\mathrm{Sr}$ (a) desistir de continuar participando, tem o direito e a liberdade de retirar seu consentimento em qualquer fase da pesquisa, seja antes ou depois da coleta dos dados, independente do motivo e sem nenhum prejuízo a sua pessoa. O (a) Sr (a) não terá nenhuma despesa e também não receberá nenhuma remuneração. Também não sofrerá qualquer tipo de prejuízo em seu local de trabalho. Os resultados da pesquisa serão analisados e publicados, mas sua identidade não será divulgada, sendo guardada em sigilo.

Salientamos que a sua participação será importante para auxiliar na promoção da interdisciplinaridade e interprofissionalidade relacionada ao atendimento à pessoa idosa.

Salientamos ainda, que sua participação poderá lhe causar risco psicológico mínimo.

Para qualquer outra informação, o (a) Sr (a) poderá entrar em contato com a pesquisadora na Escola Artes, Ciências e Humanidades da Universidade de São Paulo (EACH/USP), situada na Rua Arlindo Bettio, 1000 - CEP: 03828-000, Vila Guaraciaba, São Paulo, SP, Brasil, pelo telefone 11-994163-4161 ou pelo e-mail brunabaviera@yahoo.com.br.

\section{Consentimento Pós-Informação}

$\mathrm{Eu}$ portador do

$R G$ fui informado sobre o que o pesquisador quer fazer e porque precisa da minha colaboração, e entendi a explicação. Por isso, eu concordo em participar do projeto, sabendo que não vou ganhar nada e que posso sair quando quiser. Este documento é emitido em duas vias que serão ambas assinadas por mim e pelo pesquisador, ficando uma via com cada um de nós.

Assinatura do participante

Data:

Data:

$\overline{\text { Assinatura do Pesquisador Responsável }}$

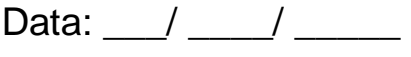

Identificação do CEP-EACH: Endereço: Av. Arlindo Bétio, 1000 - Ermelino Matarazzo - CEP: 05508-000 - São Paulo - SP - Telefone: 3091-1046 - e-mail: cep-each@.usp.br 


\section{Apêndice C - ROTEIRO PARA GRUPO FOCAL}

\section{1 - APRESENTAR OS OBJETIVOS DO GRUPO FOCAL}

Apresentar para os participantes os objetivos do trabalho e como será feito o grupo focal.

\section{2 - DEFINIÇÕES DOS CONCEITOS}

Apresentar a definição dos conceitos:

INTERDISCIPLINARIDADE

A interdisciplinaridade se refere a conceitos e teorias voltados para a compreensão de fenômenos. Envolve conhecimentos sobre determinados assuntos, que vão além do seu campo de atuação.

\section{INTERPROFISSIONALIDADE}

A interprofissionalidade diz respeito a práticas voltadas para a solução de problemas empíricos específicos. Se refere às ações desenvolvidas por profissionais atuando em conjunto, com objetivos em comum.

\section{3 - QUESTIONAR SOBRE O CONTATO COM OS CONCEITOS}

Estimular os participantes a falarem sobre suas vivências em relação à interdisciplinaridade e a interprofissionalidade

\section{4- ABORDAR FACILITADORES E DIFICULTADORES}

Neste momento questionar os participantes sobre suas percepções em relação aos facilitadores e dificultadores para a interdisciplinaridade e a interprofissionalidade.

\section{5 - QUESTIONAR SOBRE SUGESTÕES}

Quais seriam as sugestões dos participantes para que de fato a interdisciplinaridade e a interprofissionalidade aconteça em suas práticas profissionais.

\section{6 - ENCERRAMENTO E AGRADECIMENTO}




\section{Anexo A - CARTA DE AUTORIZAÇÃO}

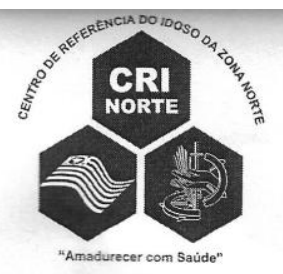

Centro de Referência do Idoso da Zona Norte

Associação Congregação de Santa Catarina - OSS

Secretaria de Estado da Saúde de São Paulo

\section{AUTORIZAÇÃO DA INSTITUIÇÃO PARA COLETA DE DADOS}

Declaramos para os devidos fins que o (a) pesquisador (a) Bruna Valquíria Baviera sob a orientação do (a) professor (a)

Beatriz AP. Ozelli Gutierrez está autorizado a realizar a coleta de dados para o (a)

Mestrado em

Gerontologia da Escola de Artes, Ciências e Humanidades - USP

intitulada:

Interdisciplinaridade e Interprofissionalidade: percepções dos profissionais envolvidos

por meio de: Utilização de questionário semi-estruturado e grupo focal no atendimento ambulatorial do idosos
no período de:
$01 / 08 / 2016$
à $15 / 09 / 2016$

Esta autorização está condicionada ao cumprimento pelo (a) pesquisador (a) dos requisitos da Resolução 466/12 e suas complementares, comprometendo-se o (a) mesmo (a) a utilizar os dados pessoais dos sujeitos da pesquisa exclusivamente para os fins científicos, mantendo o sigilo e garantindo a não utilização das informações em prejuízo das pessoas e/ou das comunidades.

Antes de iniciar a coleta de dados o (a) pesquisador (a) deverá apresentar o parecer consubstanciado devidamente aprovado, emitido pelo Comitê de Ética, credenciado ao Sistema CEP/CONEP.

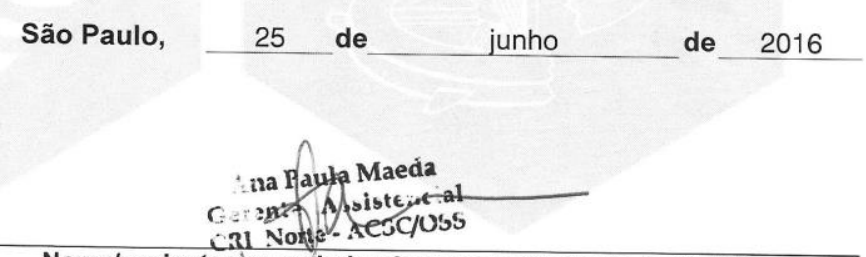

Nome/assinaturà e carimbo do responsável pela instituição ou pessoa por ele delegada 


\section{Anexo B - APROVAÇÃO DO COMITÊ DE ÉTICA EM PESQUISA}

\section{ESCOLA DE ARTES, CIÊNCIAS E HUMANIDADES - EACH/USP}

\section{PARECER CONSUBSTANCIADO DO CEP}

\section{DADOS DO PROJETO DE PESQUISA}

Título da Pesquisa: INTERDISCIPLINARIDADE E INTERPROFISSIONALIDADE:PERCEPÇÕES DOS PROFISSIONAIS ENVOLVIDOS NO ATENDIMENTO AMBULATORIAL DO IDOSO

Pesquisador: Bruna Valquiria Baviera

Área Temática:

Versão: 2

CAAE: 57303616.7 .0000 .5390

Instituição Proponente: Escola de Artes, Ciências e Humanidades - EACH/USP

Patrocinador Principal: Financiamento Próprio

\section{DADOS DO PARECER}

Número do Parecer: 1.669 .824

\section{Apresentação do Projeto:}

A proposta de estudo visa analisar a percepção dos profissionais e gestores que atuam em um serviço de atenção secundária de saúde para idosos a respeito da interdisciplinaridade e interprofissionalidade. Pesquisa aplicada, exploratória, de caráter qualitativo, que visa analisar se os profissionais e gestores que atuam na atenção à saúde do idoso reconhecem e valorizam a necessidade da interdisciplinaridade e da interprofissionalidade nos cuidados oferecidos a esta população. Será utilizado instrumento desenvolvido pela pesquisadora para a coleta dos dados, que serão analisados através da técnica de análise de conteúdo proposta por Minayo, além da realização de grupo focal.

\section{Objetivo da Pesquisa:}

A pesquisa tem como objetivo geral analisar a percepção de profissionais e gestores, de diferentes formações, que atuam em um serviço de saúde para idosos, acerca da nterdisciplinaridade e interprofissionalidade.

\section{Avaliação dos Riscos e Benefícios:}

Haverá risco mínimo aos participantes. A participação dos mesmos foi liberada pelos gerentes da instituição, que disponibilizaram os horários de reuniões destes profissionais para a coleta dos dados, a fim de que não houvesse impacto em suas jornadas de trabalho.

Endereço: Av. Arlindo Béttio, $n^{\circ} 1000$

Bairro: Ermelino Matarazzo

CEP: $03.828-000$ 


\section{ESCOLA DE ARTES, CIÊNCIAS E HUMANIDADES - EACH/USP}

Continuação do Parecer: 1.669.824

\section{Comentários e Considerações sobre a Pesquisa:}

A pesquisa está em conformidade com os requisitos básicos éticos de investigação na área da saúde.

O pesquisador deixa explicitos os riscos minimos da pesquisa.

Benefícios:

Possibilidade de ouvir a percepção dos profissionais a respeito do assunto, com a finalidade de ampliar o conhecimento sobre o tema.

Considerações sobre os Termos de apresentação obrigatória:

O TCLE esclarece que a pesquisa poderá trazer riscos mínimos psicológicos ao participante. O número de participantes foi estimada pela pesquisadora.

\section{Recomendações:}

Não há.

Conclusões ou Pendências e Lista de Inadequações:

não há.

Considerações Finais a critério do CEP:

Este parecer foi elaborado baseado nos documentos abaixo relacionados:

\begin{tabular}{|l|l|c|l|c|}
\hline \multicolumn{1}{|c|}{ Tipo Documento } & \multicolumn{1}{|c|}{ Arquivo } & Postagem & \multicolumn{1}{c|}{ Autor } & Situação \\
\hline $\begin{array}{l}\text { Informações Básicas } \\
\text { do Projeto }\end{array}$ & $\begin{array}{l}\text { PB_INFORMAÇES_BÁSICAS_DO_P } \\
\text { ROJETO 738107.pdff }\end{array}$ & $\begin{array}{c}29 / 06 / 2016 \\
15: 59: 26\end{array}$ & & Aceito \\
\hline Outros & carta_protocolo.jpg & $\begin{array}{c}29 / 06 / 2016 \\
15: 58: 48\end{array}$ & $\begin{array}{l}\text { Bruna Valquiria } \\
\text { Baviera }\end{array}$ & Aceito \\
\hline $\begin{array}{l}\text { Projeto Detalhado / } \\
\text { Brochura } \\
\text { Investigador }\end{array}$ & Projeto_Bruna_Baviera.docx & $\begin{array}{c}29 / 06 / 2016 \\
15: 48: 25\end{array}$ & $\begin{array}{l}\text { Bruna Valquiria } \\
\text { Baviera }\end{array}$ & Aceito \\
\hline Folha de Rosto & folharosto.doc & $21 / 06 / 2016$ & $\begin{array}{l}\text { Bruna Valquiria } \\
\text { Baviera }\end{array}$ & Aceito \\
\hline $\begin{array}{l}\text { TCLE / Termos de } \\
\text { Assentimento / } \\
\text { Justificativa de } \\
\text { Ausência }\end{array}$ & Termo_consentimento.docx & $12 / 06 / 2016$ & $\begin{array}{l}\text { Bruna Valquiria } \\
\text { Baviera }\end{array}$ & Aceito \\
\hline
\end{tabular}

Situação do Parecer:

Aprovado

Necessita Apreciação da CONEP:

Não

Endereço: Av. Arlindo Béttio, $n^{\circ} 1000$

Bairro: Ermelino Matarazzo

UF: SP Município: SAO PAULO

Telefone: (11)3091-1046

CEP: $03.828-000$

E-mail: cep-each@usp.br 


\section{ESCOLA DE ARTES, CIÊNCIAS Plotoformo E HUMANIDADES - EACH/USP}

Continuaçāo do Parecer: 1.669.824

SAO PAULO, 08 de Agosto de 2016

Assinado por:
Rosa Yuka Sato Chubaci
(Coordenador)

Endereço: Av. Arlindo Béttio, $\mathrm{n}^{\circ} 1000$

Bairro: Ermelino Matarazzo

CEP: $03.828-000$

UF: SP Município: SAO PAULO

Telefone: (11)3091-1046

E-mail: cep-each@usp.br 


\section{Anexo C - EXCERTOS DO GRUPO FOCAL}

P07: na minha formação da faculdade, por ser um curso bem amplo, de educação física, então tinha muitos assuntos relacionados que envolviam outras disciplinas, então a gente não aprofundou, mas teve um conhecimento básico de outras disciplinas, como a gente trabalha com o corpo e com atividade física, então envolvia também a nutrição, aspetos psicológicos também, mas não aprofundou, só uma abordagem assim mais inicial.

Moderadora: Você teve isso em relação ao envelhecimento também na faculdade?

P07: Na faculdade muito pouco. Na faculdade de educação física foi bem pouco aprofundado o envelhecimento.

Moderadora: E na pós, você teve?

P07: Na pós também foi um módulo, também de forma geral, mas nada específico.

Moderadora: Sobre envelhecimento ou sobre...

P07: Sobre alterações físicas do envelhecimento.

P14. É só precisa ver a grade de universidade. Você sabe que eu trabalhei em instituição, numa faculdade aqui de São Paulo, e o conteúdo na realidade a grade curricular começou a incluir o envelhecimento como disciplinas optativas e depois acabou colocando na grade de uns 8 anos para cá. Oficialmente de uns 10 anos que começaram a falar que era importante colocar. De 8 anos que eles começaram a incluir isso e hoje já volta como uma disciplina básica, ele entra já logo no primeiro ano nas faculdades como obrigatório. Tanto é que uma disciplina básica e depois cada curso vai focar o idoso, por exemplo na avaliação nutricional, na parte de exames bioquímicos, agora o tema é necessário sim e eu estou sabendo de outras faculdades que estão incluindo isso também na grade.

Moderadora: então hoje é obrigatório?

P14.: Isso.

Moderadora: e a questão da interdisciplinaridade e interprofissionalidade?

P14.: então, você sabe que eu já tenho uma certa idade de formação, na minha época não tinha nada disso, fui aprender na prática numa instituição onde eu fazia assistência domiciliar, e assim, ainda existe essa certa confusão, porque pelo que eu lembro em um curso de extensão foi me passada a interdisciplinaridade de outra forma, foi o que eu respondi, e assim, procurando por textos a gente sabe que não é só o conteúdo, enfim. Então desde aquela época que ainda existe algumas confusões. Por exemplo, os artigos que eles publicam, os artigos em relação à assistência domiciliar, enfim, as vezes dá nisso, mesmo o próprio autor não é? Então assim, o que o pessoal acaba focando é assim "ah então é a interprofissionalidade então é o "inter", todo mundo sabe, o que é o gerontólogo né. Eu sei dizer se a ferida é grau II, grau III ou grau IV e eu consigo te explicar. Era isso que a gente 
tava discutindo lá em baixo. Eu consigo encaminhar para a enfermagem falando "olha tá assim", enfim. Porque a gente teve uma prática, mas ainda existe muita confusão em artigos e eu não sei até que o ponto e o que é o ideal. Mas agora você dando as definições fica muito mais fácil de ver e entender esses artigos e tudo mais.

Moderadora: Só aproveitando um pouco do que você falou $F$., existe sim essa confusão na teoria. Então os artigos eles misturam as duas coisas, eles tratam tudo como interdisciplinaridade, por isso também há uma confusão nas pessoas que leem. Então, um dos papéis de eu estar trazendo os conceitos para vocês é para a gente tentar discutir melhor sobre uma coisa ou outra.

P14: Só uma coisa: a interdisciplinaridade é muito usada no meio acadêmico. Por isso sim. Tanto é que o conteúdo, como eu estava comentando com as meninas na semana passada, a interdisciplinaridade hoje é assim uma disciplina está relacionada à outra. Vou dar um exemplo: tecnologia dos alimentos. Eu entrei lá para dar aula de técnica dietética. Então assim, quando eu ia orientar o aluno a fazer determinadas coisas com o liquidificador eu falava "lembra da técnica que vocês aprenderam de higiene? ". "Ah, mas é pauta da graduação". Mas eu como professora de "T.D." tinha que saber o que o outro vai dar para reforçar o conteúdo. Então assim, era o conteúdo básico, definição, mas um auxiliando o outro, complementando e até mesmo reforçando o conteúdo da disciplina.

P11: Na graduação eu não tive muito sobre interdisciplinaridade, mas nas duas pós que eu fiz, tanto na de ortopedia quanto na de geronto foi bem abordado assim nas matérias. Até na ortopedia, por exemplo, falou muito do processo de envelhecimento, que quem fez antes não tinha muito isso. Daí entrava assim, por exemplo, vinha um professor de fisiologia do exercício, e ele entrava na parte de alimentação, de atividade física, de alterações de músculos. Então assim, abordava vários assuntos que não só de fisiologia, como vinham também convidados de Nutrição e falava e abordava assuntos de fisiologia também. E na de geronto, eu tive mais a parte de interprofissionalidade, não diretamente com o paciente, mas traziam alguns casos de geronto, como eram, tinham várias especialidades, inclusive médico, e eram muitos casos para serem discutidos e serem resolvidos entres equipes, então, dentro da sala de aula eram montados os grupos, com as equipes: um médico, uma fisio... Você sabe né? Então traziam muitos casos assim e foi bem abordado.

P10: essa abordagem discutia com todas especialidades. Dentista era só eu. Mas era uma coisa muito assim... Deu uma base para a gente trazer para cá também, porque a gente já vivencia isso todos os dias aqui com todos vocês. Essa esta bagagem que nós trouxemos da geronto, eu acho que está integrando com todas as áreas daqui, eu acho isso tudo de bom. $\mathrm{Na}$ faculdade, a gente tem as matérias lógico, mas o conteúdo é muito fraco. Muito fraco. Você não consegue saber. Você dava uma pincelada. Mas no último ano já entrou, na época 
que eu fiz, processo de envelhecimento, o idoso, por isso eu fiz um trabalho sobre idosos já na graduação. Mas foi muito básico, muito básico mesmo.

Moderadora: Só aproveitando o que vocês duas falaram para tirar uma dúvida: vocês discutiam os casos e era uma discussão teórica. Vocês colocavam em prática depois?

P11: Sim. Só que assim, eram casos que vinham diretamente do ambulatório, então em casos que existiam, traziam para a gente discutir, quem trazia normalmente levava isso para 0 ambulatório, mas assim, dava para eu extrair bastante coisa de lá para o pessoal mesmo, não da equipe, por não tinha como.

Moderadora: então vocês não estavam lá direto atuando?

P11: Não.

P10: nós ficamos pouco dentro do ambulatório para vivenciar o caso, por exemplo...

P14: acho que na prática clínica, quem trabalha com a assistência, acho que fica mais fácil não só aprender ali na prática como aplica este conteúdo teórico, por mais que seja básico, você vai se especializando e os outros colegas também ali. É para aumentar este conteúdo né.

P13: Na minha experiência na graduação, eu já tive um contato bem importante com a interdisciplinaridade. Eu acredito que tem a ver com a minha área, que eu sou terapeuta ocupacional, na graduação a gente estudava muito os fundamentos da terapia ocupacional e as referências da TO são, digamos assim, os limites disciplinares da TO se ultrapassam, então a gente estuda junto com alunos da psico, a gente faz outras disciplinas junto com a fisio, no sentido assim, de que o saber, que aquele conhecimento não é importante só para minha área, mas para todos. Então na minha faculdade eu tive esse contato, e ainda na faculdade também, eu tive um contato interprofissional a partir dos estágios, o primeiro deles foi em reabilitação baseada na comunidade. A gente já fazia interprofissionalmente, discutindo a interdisciplinaridade. Então na faculdade foi isso. E na pós...eu acho que na faculdade é mais interdisciplinaridade do que interprofissionalidade, e aí na pós, eu fiz a pós em geronto também, e a experiência foi também para convergir, muita interdisciplinaridade e muita interprofissionalidade principalmente.

P16: Bom, na minha graduação praticamente nada de envelhecimento, muito pouco, teve assim no máximo pouca coisa de avaliação nutricional no idoso, mas muito pouco.....sarcopenia ou alguma coisa do tipo. Eu tive vários, é, não tive nada de interdisciplinaridade nem de interprofissionalidade na graduação. Comecei a ter mais contato depois que eu saí da faculdade, eu comecei a fazer atendimento ambulatorial, numa oportunidade de surgiu em um ambulatório $X$, e aí eu comecei a ter contato com a equipe multiprofissional. Não vou falar que a equipe era inter, mas multi, porque cada um ainda atuava muito separadamente. E aí, nesse tempo, eu comecei a trabalhar em instituição de longa permanência, onde a gente também era mais multi do que inter, e com o passar do 
tempo, com as mudanças nas direções nas lideranças, a gente começou a ser mais interdisciplinar. A gente começou a ter reuniões frequentes, de discussões de caso e tal, onde a gente começava a entender um pouquinho da área do outro. E depois a gente começou a perceber o quanto a gente estava começando a ser transdisciplinar, começando a colocar já em prática coisas que a gente já aprendeu em um momento com o outro profissional. Por exemplo, em instituição de longa permanência eu acho que é um pouco mais fácil a gente colocar isso em prática. Por exemplo, eu sei que aquele paciente naquele momento não vai ter uma avaliação da Fono, mas eu sei que, por exemplo, ele está com um alimento com a consistência $X$, eu já posso solicitar uma consistência mais segura para aquele paciente até a avaliação da Fono.

Moderadora: isso você adquiriu conversando com o outro profissional?

P16: Exatamente. Com as conversas, com os conhecimentos, a gente sabe que a consistência $X$ é mais segura até uma avaliação, então esse é um dos exemplos né, que a gente começou já a colocar em prática. Então eu acho que esse contato direto com o paciente, conversar lá diretamente com ele naquele momento e a gente aprendendo, a gente começa a ser um pouco mais transdisciplinar. E tem muita coisa também a que a gente aprendeu aqui na instituição, por conta de todas as discussões, as triagens, todas as avaliações, a gente discutiu tanto tempo as triagens e os instrumentos, fez com que, com certeza, a gente ganhasse muita prática e começasse a afinar um pouco mais nossos conhecimentos, então eu acho que é isso.

P04: então, na minha graduação, eu tive mais contato com esta questão do interdisciplinar, essa parte dos professores foi um pouco mais para o final da graduação. $E$ aí eu tive mais contato com o envelhecimento porque eu tive a oportunidade de fazer estágio aqui. Eu tinha uma professora que já trabalhava aqui e aí eu fui me interessando por essa área. Também me deu essa possibilidade de ampliar o conhecimento em relação ao idoso mais por interesse próprio, porque dentro da graduação, na grade curricular não tinha uma disciplina voltada para o envelhecimento.

Moderadora: então foi mais porque você se interessou e buscou.

P04: Sim. E aí essa esta questão mais entre as profissões, foi mais na prática mesmo, que a gente foi com o tempo construindo aqui também, porque não era assim, e acho que hoje a gente tem isso muito mais amadurecido e claro de que se eu estou com outro profissional então eu não vou estar lá querendo "meter o bedelho" no que não é meu. Mas é uma coisa que se completa e soma para o paciente. E antes a gente tinha essa confusão, "porque psico atender com TO, psico atender com Fisio, ai não pode, ai isso não" então gerou aquela polêmica, e hoje a gente isso muito claro de que quando a gente junta as profissões só agrega, tanto para a gente quanto para o paciente.

Moderadora: e por que você acha que antes gerou uma polêmica e hoje não gera mais? 
P04: acho que por conta da nossa formação, a gente não tem isso também claro na faculdade e até em pós que a gente faz, isso não é muito aprofundado.

P14: a questão dos conceitos também, conceitos na geronto.

P04: também. Não definir muito bem cada coisa, e as vezes acho que enrijece, ao invés de ter aquela coisa mais permeável, fica mais enrijecido.

Moderadora: Por que que você acha que depois foi mais aceito? O que fez você sentir que não era tão polêmica, que aquilo era bom?

P04: Foi a prática né, porque a gente percebeu que tinha benefício para o paciente também no tratamento. A gente conseguiu ter uma comparação de como era antes e como tava agora com a participação de outros profissionais. E daí a gente percebeu que melhorou tanto para a gente quanto para o paciente.

Moderadora: então deu resultado?

P04: sim.

P13: eu já percebo, sobre o que a colega acabou de colocar, o que faz a gente se sentir à vontade para estar com outro profissional e não se sentir invadindo ou invadido é muito do vínculo que a gente faz. O vínculo que a gente vai construindo, entre psico e TO, por exemplo, é uma coisa assim, a gente vai se permitindo, um experimentar o outro, trocando, "o que você achou?", "como é que você usou?". E tem um vínculo afetivo também, que a gente convive no dia a dia, a gente toma um cafezinho, pega ônibus junto, tudo isso vai somando para dar uma certa liberdade né, para gente chegar e falar "nossa, mas isso", a gente fica livre, se sente mais à vontade.

Moderadora: Então poder conviver com os outros, em espaços que não sejam só o de atendimento, você acha que faz diferença?

P13.: Muita.

P09: Durante a graduação, eu tive módulos que eram comuns a todas as disciplinas da área da saúde da minha faculdade. Então quando era trabalho especifico da saúde, eram escolhidos alguns pacientes da comunidade, eram formados grupo interdisciplinares, que atuam no domicílio ou instituições, então a gente montava o plano de tratamento juntos e atuava após as discussões.

Moderadora: isso foi mais no começo da sua graduação ou mais para o final?

P09: foi no terceiro ano, mais ou menos. A vivência da faculdade que eu fiz, eles prezavam muito isso para o profissional, eles incentivavam essa troca. E na pós que eu fiz, também a prática tanto interdisciplinar quanto interprofissional era bastante forte.

Moderadora: Então vamos para o próximo tópico. Foi muito importante ouvir um pouco a experiência que cada um teve. Agora eu queria que vocês me falassem um pouco o que vocês acham que facilita que a interdisciplinaridade e a interprofissionalidade aconteçam no trabalho 
de vocês, tanto nesta instituição quanto em outras instituições que vocês trabalharam. Então é o que vocês acham que ajudava, que facilitava para isso acontecer, que contribuía para isso acontecer. E também o que não contribuía, o que dificulta que isto aconteça. Então, com base nas experiências de vocês, o que vocês acham que atrapalha o acontecimento da interdisciplinaridade e da interprofissionalidade e o que vocês acham que ajuda.

P16: Bom o que eu acho que ajuda seria, além do nosso conhecimento, é da nossa motivação de trabalhar, de querer o melhor para o paciente. Enfim, acho que esse é o principal para mim. E eu acho que o que complica muito este trabalho, seriam as partes mais burocráticas e administrativas, às vezes, do lugar onde a gente trabalha né. A gente poderia atuar muito mais se talvez não tivessem, não digo regras, mas metas, a gente tem que ter um controle muito grande para não perder mão ou qualquer coisa do tipo. Então acho que isso complica um pouco mais o trabalho, enfim.

P04: Eu acho assim, o que ajuda é o objetivo comum mesmo. Eu acho que esse é o fio da meada. Quando a gente consegue pensar junto acho que as coisas vão fluindo melhor. É mas dentro deste percurso, várias coisas vão emperrando aí. Acho que esta questão administrativa é uma das básicas assim, então "ah eu não posso bloquear a agenda para dois profissionais atenderem o mesmo paciente". E a gente tem essa questão mais interprofissional quando é grupo, por aí a gente consegue mobilizar mais atendimentos para um ou mais profissionais estarem ali. Agora quando o paciente é um só e a gente precisa ter essa relação com o outro profissional aí a gente não consegue caminhar porque não para atender 3 pessoas com 1 paciente. Então esta é a questão burocrática. E acho que tem também o perfil do profissional. Nem todo profissional se coloca nessa relação. Eu sei que tem pessoas que falam "prefiro atender sozinho" e aí a gente também tem que lidar com isso. Não dá para obrigar o outro a fazer uma coisa que não vai ser produtiva para ele.

P13: só somando ao que foi dito, tem uma coisa que facilita, da minha experiência, que é o sentimento de segurança de cada profissional em relação ao seu vínculo de trabalho. Porque se a gente está em uma relação disputada, quer dizer, "então eu vou fazer o trabalho da psico e a psico vai se sentir ameaçada". Acontece muito isso nos bastidores, quando os serviços se propõem a fazer o trabalho inter, hospital por exemplo, e você quer fazer uma proposta, mas isso não é seu. De uma forma as vezes não dita, você não pode fazer, porque tem uma coisa assim que é defender seu espaço nessa briga categórica, que não necessariamente é uma boa prática, mas influencia na relação de trabalho

P15: eu acho que o facilita bastante assim é quando a gente faz discussão de caso, tem reunião com vários profissionais de um mesmo paciente. Com isso a gente aprende e também tira um pouco essa, lado meio, não é místico, como fala? Quando você mistifica, é isso? Desmistifica a situação, você tem medo de alguma coisa aí eu começo a ver que não é bem aquilo. Eu acho que a hierarquia também as vezes atrapalha, igual a J. falou, desta coisa 
assim "ah é o médico", ou a pessoa ali tem um cargo, e ele tem medo um pouco de se abrir para conhecer um outro profissional acha do mesmo paciente que ele atende sabe. Eu acho que isso atrapalha, e por um outro lado eu acho que a discussão ajuda.

P05: Bom eu acho que o que favorece é a gente ter muita clareza do nosso papel. Se cada um de nós sabe o que é o nosso papel na situação com o paciente, nós saberemos onde estará o seu limite. E a gente não vai ter atingido esse objetivo que é o tratamento. E aí o que eu preciso para melhorar isso? De outras opiniões, de outros conhecimentos que não é o meu somente. E o que dificulta, é justamente o contrário, se eu não tenho clareza do que é o meu eu vou fazer o do outro. E aí essa coisa de vaidade, de você tomar o meu espaço. Quando cada um sabe o seu papel isso não acontece. Mas eu acho que, além dos problemas burocráticos, esse é o problema maior. Porque a burocracia a gente dribla, a gente contorna, a gente dá um jeito. Mas agora se a equipe ou o outro profissional que está comigo não tiver essa clareza, eu não faço esse trabalho e aí é mais difícil.

P14: Colocar aqui um caso de outra instituição. Isso funcionou tão bem, que eu e a $D$. (fonoaudióloga), a gente trabalhou no mesmo lugar. E um dia a gente chegou lá para visitar um dos pacientes, eu desci da Kombi toda feliz e disse "oi prazer, meu nome é F., eu sou a fono". E a D. olhou para mim e disse "você é a fono?". É que a gente trabalhava tão junto (risos). É igual no nosso Ambulatório de Disfagia aqui, quando eu saio de férias de uma forma bem tranquila porque eu sei que o paciente que estiver em risco nutricional, eu sei que a $D$. dá conta no reforço de alguma informação. E em nenhum momento isso para mim é um risco, e isso já a muito tempo. Porque essa forma de trabalhar em conjunto, do mesmo jeito, eu encaminho um paciente para ela, é a mesma coisa que a A. falou, a gente já manda o paciente já com o tipo de consistência que normalmente ela iria ofertar, porque, se eu estou com dificuldade ela reforça a consistência. A gente tem uma ideia de que com aquele quadro o paciente irá acontecer isso isso isso, a consequência de já mandar com a prescrição. Eu não vou esperar 1 mês ou 2 meses para alterar a consistência. Então esse trabalho em conjunto é muito interessante. Se ela saí de férias, porque se o caso é muito grave, a gente já entra com a mudança de consistência, aí você já pede a avaliação. E do mesmo jeito, os exercícios que o terapeuta ocupacional, a gente já vai...Não é que a gente vai prescrever, "aqui oh, você..." vai fazendo aquele contato com ele. É o reforço das orientações. Quer dizer, em nenhum momento a gente vai estar fugindo, agredindo ou sendo antiético.

Moderadora: e o que você acha que possibilitou você ter essa segurança em relação ao outro profissional?

P14: Prática. Confiança.

P05.: eu acho que a prática mostra para você o que, a necessidade de buscar isso, porque você não dá conta. Dentro da Geronto, a gente tem que ter muita consciência de que a gente trabalha com pessoas, e não com doenças. Porque tratar a doença é fácil. 
P14: Sim

P05: agora tratar a pessoa é muito difícil. E olha que todos nós fizemos área da saúde, pouquíssimos de nós tem essa formação na faculdade. A gente aprende a tratar doença.

P14: e as vezes não é o paciente que a gente trata, é o cuidador.

Moderadora: então essa flexibilidade vocês acham que também faz diferença?

P14.: sim.

P05: totalmente.

P13: Só queria pontuar, interessante o que as colegas estão colocando agora. Pontuar o vínculo que existe entre estas duas profissionais, que é anterior a este momento, que passa anos assim [...] esse vínculo..., o quanto este vínculo é válido em tudo isso que está sendo colocado, de cada um saber seu papel e tudo mais. Esse vínculo de tanto tempo de convívio e de contato, de uma amizade, vamos dizer, deixa um espaço tão confortável, que você consegue transitar, você consegue não se sentir invadindo.

P16: é uma segurança né, que você tem no profissional, de você conhecer o trabalho dele, de você entender qual a importância do outro profissional também no seu trabalho. Porque as vezes é uma cadeia. Eu dependo do trabalho do outro para que o meu também seja efetivo. Então, um exemplo assim básico, um paciente lá com fragilidade, sarcopenia, eu preciso muito do fisioterapeuta. Preciso do trabalho do fisioterapeuta, por mais que ele esteja emagrecido, é importante que além da minha atuação tenha a atuação do fisioterapeuta, senão não tem resultado né. Então vai da gente entender.

P10: tem profissionais que não dão essa abertura né. Nós enfrentamos na nossa área é um pouquinho complicado. Porque dentista a turma acha que tem que tratar da boca e acabou. Para nós da geronto não tratamos da boca, nós tratamos o paciente como um todo. Um paciente como um todo, necessitando de todos os profissionais agregados, e nem todos os profissionais entendem isso ou não aceita.

P16: Eu acho que também uma das coisas que ajuda a dificultar, também pode ser assim, uma pessoa de hierarquia superior e as vezes, não que ele não tenha entendimento, mas as vezes é dar a oportunidade do novo, de algo diferente. Uma forma, sei lá, de expressar meu trabalho de uma forma diferente. As vezes é "é assim assado, vai ficar assim assado". As vezes acaba também dificultando a vontade do profissional, a motivação que ele tem de tentar colocar algo novo na prática, quem sabe da interdisciplinaridade ou da transdisciplinaridade. Moderadora: o que vocês acham então que poderia ajudar? Vocês teriam sugestões de mudanças que poderiam acontecer nas instituições para isso pudesse acontecer?

P16: então na verdade, eu acho que a palavra essencial seria conhecimento. Propagar conhecimento daquilo que a gente faz. A gente ter essa segurança da prática e a gente 
demonstrar, falar com o outro, passar adiante. O conhecimento e a informação a gente tem que passar adiante. Não é por passar o conhecimento que eu tenho para Fulano ou Beltrano, que essa pessoa, que eu vou deixar de existir, que ela vai tomar meu lugar ou qualquer coisa do tipo. Eu acho que conhecimento, mostrar as informações e os benefícios que a gente tem da forma que a gente atua. Eu acho que esse pode ser um dos caminhos.

P04: é, eu pensei em várias coisas, mas assim é um pouco além dessa ideia que a gente tem que isso tem que vir a partir da graduação. Acho que isso tem que ser uma coisa contínua durante a formação do profissional. Uma outra coisa pensando na nossa atuação mesmo, e aqui como um Centro de Referência. Somos um Centro de Referência, então, teoricamente, somos vistos como exemplo. Então pensando nessa ideia de rede, e de como as coisas vão circulando, acho que talvez oferecer capacitações, para a rede, de como a gente funciona aqui, para que eles também se sintam empoderados de que eles podem fazer isso também, não só a gente. E evita também de a gente absorver todo mundo aqui, porque somos uma referência e a aqui é o modelo de exemplo para tratamento do idoso. Eles também podem fazer isso.

P13: a minha percepção é que a experiência na graduação e na pós é muito mais comungante, é muito mais importante, porque, eu vou falar por mim. A minha experiência foi tão rica, que hoje, quando eu atendo um paciente domiciliar, eu me sinto só, eu não consigo. Eu tenho que pegar o telefone do fisioterapeuta e eu tenho que trocar. De saber o que a fono está fazendo. É uma coisa assim, porque eu aprendi a ser assim. Na graduação eu tive experiências que, mais do que estudar a interdisciplinaridade e a interprofissionalidade, foi possibilitar a vivência disso. Porque aí você visualiza..."eu não vou dar conta disso sozinha". Você cai na real. Ninguém dá conta sozinho.

P05: foi porque você aprendeu a fazer assim. Só que a maioria aprendeu de outro jeito. $\mathrm{Na}$ prática começou a sentiu uma necessidade de um complemento do que aprendeu a fazer. $E$ aí faz diferença. 